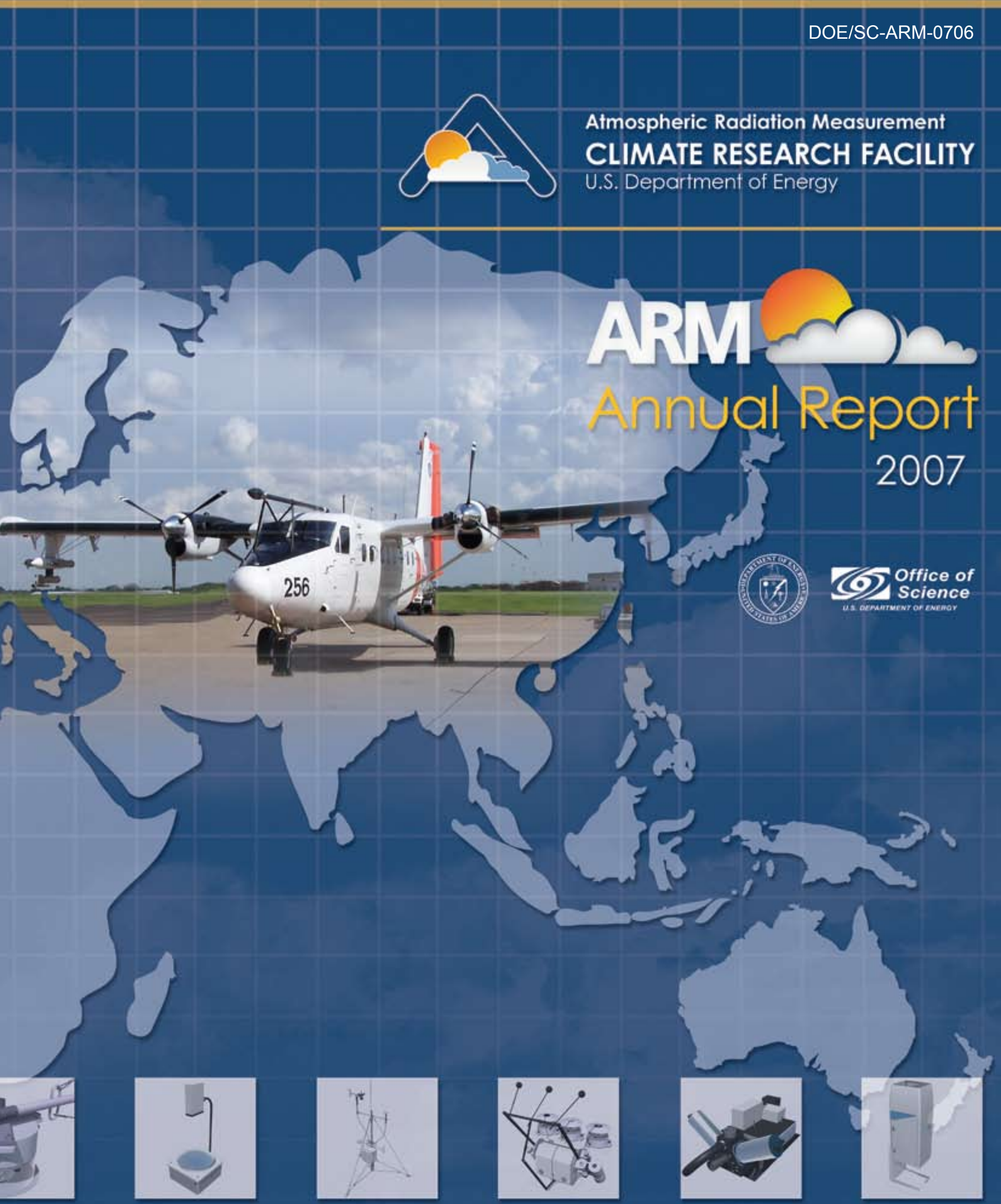




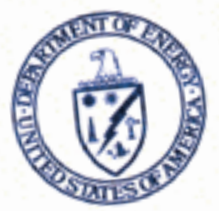

Department of Energy

Washington, DC 20585

November 1,2007

U.S. Department of Energy (DOE) in 1990 to reduce

The ARM Program was established by the U.S. Departin climate models. Since then, it has uncertainties related to cloud and radiative science and infrastructure. The science plels, while the evolved into two primary compon improve both regional and global clim)-provides state-of-the-art continues to focus on research ARM Climate Research Facility from around the world. infrastructure-through the ARM aircratt, and datastems for scientific users from This annual report describes the purpose and structure of accomplishments in 2007 . Notable achicvemito

Successful review of the ACRF as a user facility by the DOred the importance of the scientific Research Advisory Committee. The subco international research comulinity. impacts of this facility, and its varace Interaction Campaign. Thisumentation at the ACRF

Leadership of the Cloud Land involved enhanced surface Humilis Aerosol Processing interdisciplinary field campain in concert with the Cumulus site and, coordination of nine aircraft Southern Great Plains dit DOE Atmospheric Science Study sponsored ARM Aerial Vehicles Program. through the ARM Acroyment of the ARM Mobile Facility in Germany, site.

- Successful deployments and drawing almost 5000 visitos to the sileather forecast models from dozen guest instruments in representation of radiative Fransfer in.

- Key advancements in the redium-Range Weather Forecasts. the European

- Development of sefiles to Niamey, Niger, Africa. issue (February 2007) of the Bulletin of the Publication of three research papers

These are just a few examples of the progress made by the ARM. Thank you for your interest in we hope you will read on to learn more about our acfich and support of DOE's important clime tham slapats.

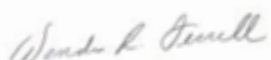

Wanda R. Ferrell, Ph.D.

Program Director ARM Climate Research Facility
Kiran Alapaty, Ph.D.

Program Director

ARM Science Program

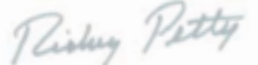

Rickey Petty

Program Director 


\section{Table of Contents}

Program Overview.

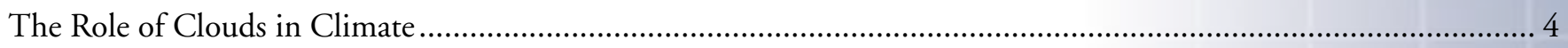

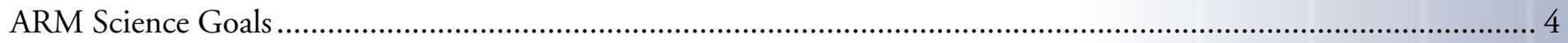

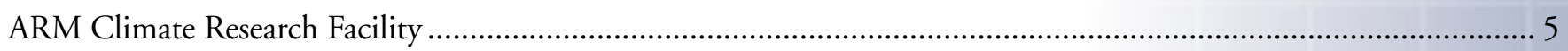

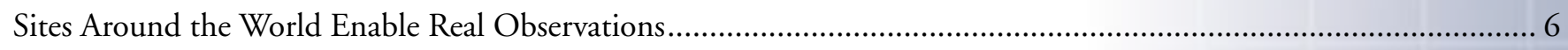

State-of-the-Art Instrumentation Yields Comprehensive Data Sets ................................................................... 8

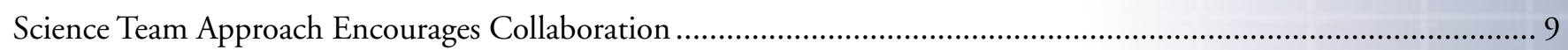

Working Groups Provide Leadership, Focus on Specific Problems .................................................................... 9

Oversight Ensures Relevant Science, Promotes Facility Use.......................................................................... 10

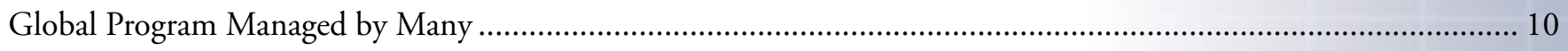

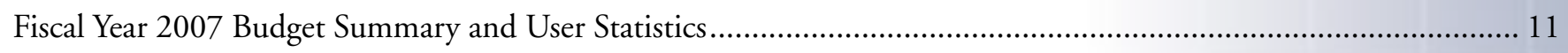

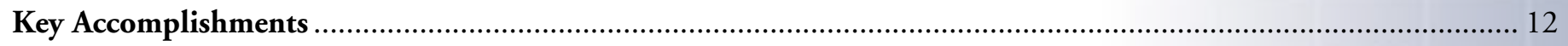

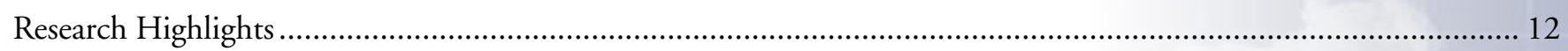

- Will a Warmer Climate Lead to Stronger Storms?

- Improving the Treatment of Clouds in Climate Models

- Long-Term Data Set Improves Understanding of Impact of Vertical Location of Clouds on Climate

- Arctic Cloud Study Confirms Question About Ice Crystal Formation

- Advances in Global Weather Forecasting

- Tropical Cloud Study Yielding Insights About Cloud Ice and Radiative Forcing

- Using Lidars to Retrieve Optical Depth of Thick Clouds

Featured Field Campaigns.

- Conditions Range from Classic to Extreme During Continental Field Campaign

- Arctic Winter Provides Window of Opportunity to Improve Climate Models

- Research in Germany's Black Forest Will Improve Precipitation Forecasts

Infrastructure Achievements

- Site Operations

- Instrument Enhancements

- Data Delivery

- Communication, Education, and Outreach

FY 2007 Field Campaigns 30

FY 2007 Publications 36

On the cover: A heavily instrumented Twin Otter joined six other aircraft during the Cloud and Land Surface Interaction Campaign in June 2007 at the ACRF Southern Great Plains site. Coordinated by the ARM Aerial Vehicles Program, the aircraft flew at various heights throughout the domain to obtain in-situ measurements of cloud and aerosol properties and carbon cycle gases - key science objectives for the campaign. See the Featured Field Campaigns section of this report for more information. 
Research has shown that cloud radiative forcing and feedbacks are one of the major sources of uncertainty in simulations of climate change over the next century. The ARM Program focuses on obtaining continuous field measurements of atmospheric properties and processes, and from these measurements, developing data products that promote the advancement of climate models.

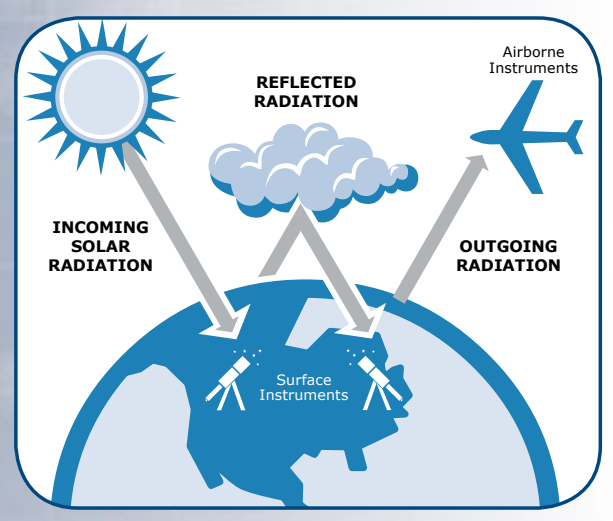

ARM researchers use data collected from ground-based and airborne instruments to study the natural phenomena that occur in clouds, and how those cloud conditions affect incoming and outgoing radiative energy.

\section{(9) Program Overview}

\section{The Role of Clouds in Climate}

Sophisticated computer models of the Earth's climate system are the principal tools used by scientists for simulating climate and predicting its change. The credibility and validity of these models are dependent upon, among other things, their ability to correctly represent physical processes, such as the exchange of energy between Earth and the atmosphere. The representation of cloud processes and their impact on this energy exchange-referred to as Earth's radiation balance-has been recognized for decades as the source of much uncertainty surrounding the prediction of climate variability and change.

The U.S. Global Change Research Act of 1990 established an interagency program within the Executive Office of the President to coordinate U.S. agency-sponsored scientific research designed to monitor, understand, and predict changes in the global environment. To address the need for new research on clouds and radiation, the U.S. Department of Energy (DOE) Office of Science established the Atmospheric Radiation Measurement (ARM) Program, managed through the Office of Biological and Environmental Research. As part of the DOE's overall Climate Change Science Program, a primary objective of the ARM Program is improved scientific understanding of the fundamental physics related to interactions between clouds and radiative feedback processes in the atmosphere.

\section{ARM Science Goals}

A major emphasis of the DOE Climate Change Research program is on understanding climate forcing, especially the radiation balance from the surface of the Earth to the top of the atmosphere, and how changes in this balance due to increases in the concentration of greenhouse gases in the atmosphere may alter climate. Much of the research is focused on improving the quantitative models necessary to predict possible climate change at global and regional scales.

Research in the ARM Program focuses on resolving the greatest scientific uncertainty in climate change prediction - the role of clouds and their interactions with solar and infrared radiation. ARM seeks to develop a better quantitative understanding of how atmospheric properties, including the extent and type of cloud cover and changes in aerosols and greenhouse gas concentrations, affect the solar and infrared radiation balance that drives the climate system. It also includes support to archive and analyze climate change data, including continuous data from fixed research sites, and data on greenhouse gas emissions and concentrations and to make such data available for use by the broader climate change research community.

ARM's goal is addressed through a combination of continuous ground-based observations, short-term field campaigns, data analysis, modeling of local and regional physics, and development of parameterizations for global models. Through these activities, the ARM Program seeks the answers to two principal questions:

- How accurate are both solar and infrared radiative transfer calculations for any given column of the atmosphere? 
- How well can cloud properties in a column of the atmosphere be predicted from knowledge of larger-scale atmospheric properties?

Because of the complexity and global scope of the research involved in answering these questions, the ARM Program collaborates extensively with other laboratories, agencies, universities, and private firms in gathering and sharing data. This collaborative approach allows ARM to leverage its investment in research sites, instruments, data, and science to gain the knowledge necessary to improve the accuracy of the computer models used to simulate global and regional climate changes.

\section{ARM Climate Research Facility}

Through the ARM Program, the DOE funded the development of several highly instrumented ground stations for studying cloud formation processes and their influence on radiative transfer, and for measuring other parameters that determine the radiative properties of the atmosphere. This scientific infrastructure, and resultant data archive, is a valuable national and international asset for advancing scientific knowledge of Earth systems. In fiscal year (FY) 2003, the DOE designated the ARM infrastructure as a national scientific user facility: the ARM Climate Research Facility (ACRF). The ACRF has enormous potential to contribute to a wide range of interdisciplinary science in areas such as meteorology, atmospheric aerosols, hydrology, biogeochemical cycling, and cloud physics, to name only a few.

Three primary locations- the Southern Great Plains (SGP), Tropical Western Pacific (TWP), and North Slope of Alaska (NSA)—plus aircraft and the ARM Mobile Facility (AMF) are heavily instrumented to collect massive amounts of atmospheric measurements. Using these data, scientists are studying the effects and interactions of sunlight, infrared radiation, and clouds to understand their impact on temperatures, precipitation, and other aspects of weather and climate. As part of this effort, ARM scientists and ACRF infrastructure staff analyze and test the data files to create enhanced data products. Software tools are provided to help open and analyze these products, which are made available for the science community via the ARM Archive (www.archive.arm.gov) to aid in further research.
Radiative Heating Profiles on the Up and Up. Chaired by ARM Chief Scientist Warren Wiscombe, a 2-day Radiative Heating Profile Workshop was held in January 2007 at the Scripps Institute of Oceanography. Radiative heating profiles describe how radiative energy is deposited in the atmosphere, where it affects cloud evolution and atmospheric circulation. The purpose of the workshop was to identify and discuss techniques for measuring radiative heating profiles, which is very difficult due to the extreme variability of clouds in both time and space. Most of the 35 participants presented their related research results.

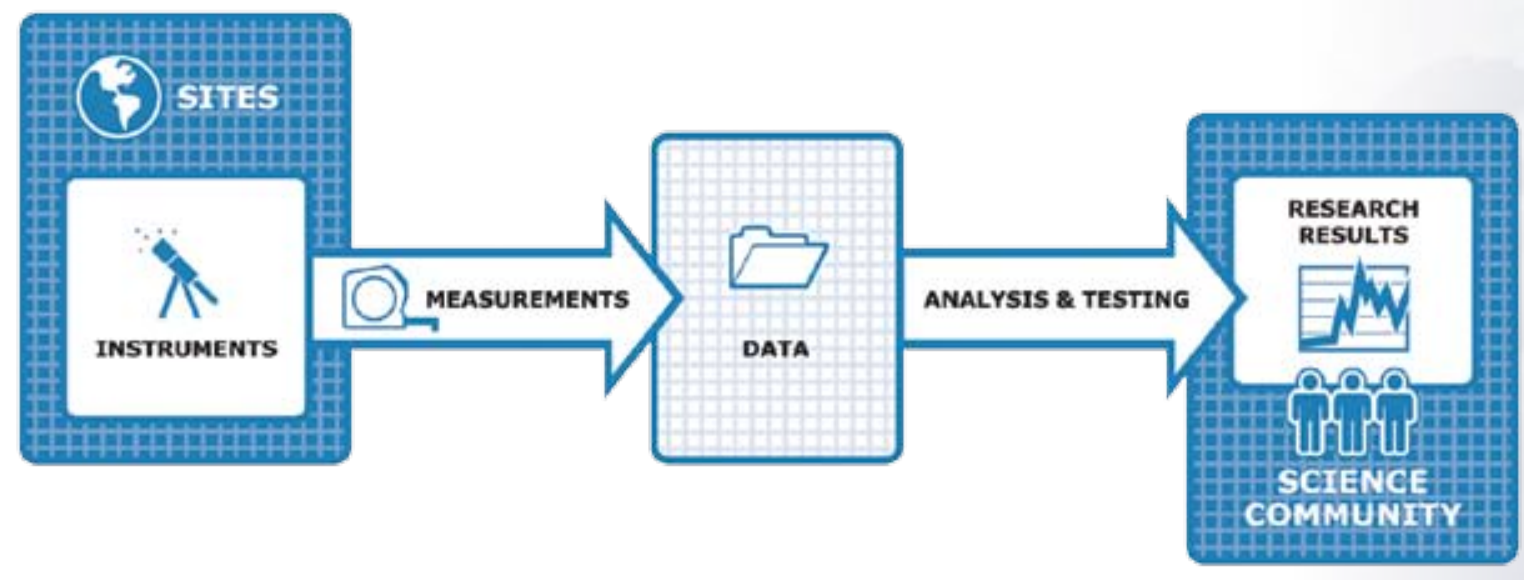


Solar Radiation Measurements Aid Renewable Energy Research. In May 2007, the DOE National Renewable Energy Laboratory released an update to the National Solar Radiation Database, which contains hourly solar radiation data for 1454 stations in the United States. This update included measurements from instruments at the ACRF SGP and NSA sites-2 of only 40 stations in the updated database that include solar radiation measured in situ.

Also in FY 2007, the ARM broadband solar irradiance data from the SGP were selected by the DOE Office of Energy Efficiency and Renewable Energy for supporting the Renewable System Integration Study. This study addresses the potential impacts on the stability and operation of the electricity grid as renewable energy technologies provide a significant share of our nation's electricity demand.

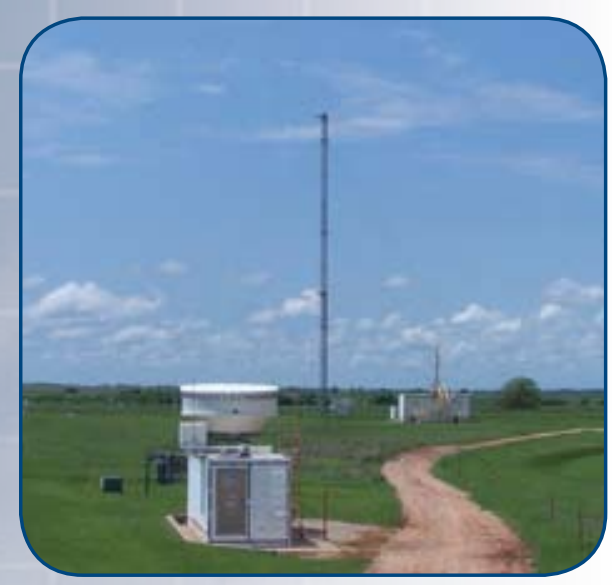

The SGP site in Oklahoma provides a wide variability of cloud types and surface flux properties, and large seasonal variation in temperature and humidity.

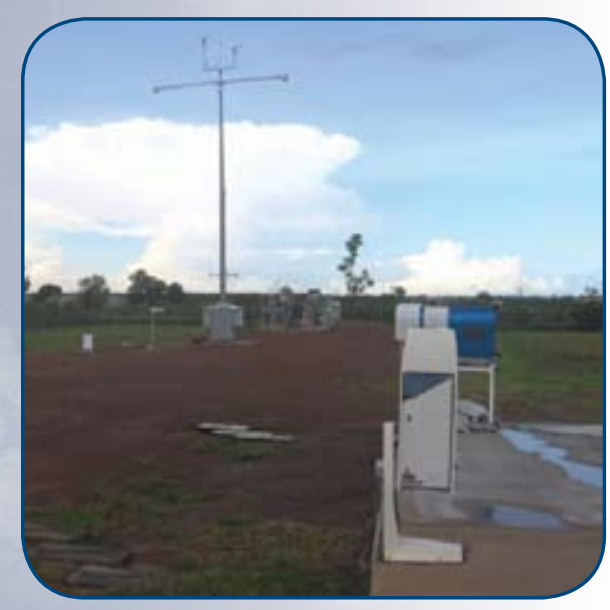

Deep atmospheric convection is one of many processes in the TWP locale that combine to drive global climate.

\section{Sites Around the World Enable Real Observations}

A central feature of the ACRF is a set of instrumented field research locales for measuring atmospheric radiation and the properties controlling this radiation, such as the distribution of clouds and water vapor. To obtain the most useful climate data, three locales were chosen that represent a broad range of weather conditions.

\section{Southern Great Plains}

The SGP site was the first field measurement site established by ARM. The SGP experiences a wide variety of cloud types and surface flux properties, as well as large seasonal variations in temperature and humidity. The site consists of a highly instrumented Central Facility near Lamont, Oklahoma, and smaller "satellite" facilities scattered throughout approximately 142,000 square kilometers in northcentral Oklahoma and south-central Kansas.

Cooperative partnerships have evolved with a variety of government laboratories, agencies, and universities, permitting collaborative use of several state-of-thescience radar and climate-observing systems and networks. Collection of continuous measurements at this location began in 1994, with a complete suite of instruments operating since 1996. This site is now the largest and most extensive climate research field site in the world.

\section{Tropical Western Pacific}

The TWP locale spans the equatorial region from Indonesia to the dateline. This area-referred to as the Pacific "warm pool"-is characterized by warm sea temperatures, deep and frequent atmospheric convection, high rain rates, strong coupling between the atmosphere and ocean, and substantial variability associated with El Niño.

Three instrumented sites operate in the TWP locale. The first of these sites was established in 1996 on Manus Island, Papua New Guinea. Site operations on Manus are conducted in collaboration with the Papua New Guinea National Weather Service. The second TWP site was established on Nauru Island in 1998. Nauru operations are performed with the cooperation of the Nauru Department of Island Development and Industry. A third TWP facility began operating in 
April 2002 in Darwin, Australia, in partnership with the Australian Bureau of Meteorology. Unlike the Manus and Nauru sites, the Darwin facility collects data typical of tropical land convection and monsoon circulations.

\section{North Slope of Alaska}

The NSA locale is situated on the edge of the Arctic Ocean. This area provides important information for ARM research because unique climate processes-such as planetary heat loss from the poles and extensive sheets of ice that affect solar absorption and sea level—occur at high latitudes. Due to generally cold temperatures, atmospheric water vapor concentrations in the Arctic are quite low, allowing infrared radiant energy from the surface to escape through the atmosphere more easily than in other regions.

The NSA's principal instrumented facility was installed near Barrow in 1997, followed by a smaller remote site in Atqasuk in 1999. Routine operations at these sites are conducted in partnership with employees of Ukpeagvik Iñupiat Corporation/ Science Division.

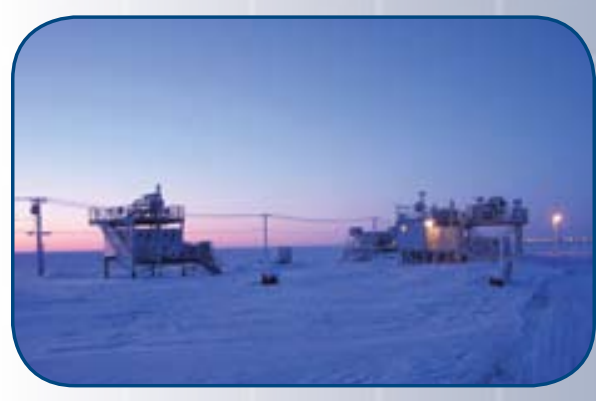

The NSA provides data about cloud and radiative processes in the Arctic, which has been identified as one of the regions most sensitive to climate change.

\section{Education and Outreach Program Garners Award from National Science Foundation.}

In collaboration with the Teachers Domain website, the ACRF Education and Outreach Program developed a winning proposal for supporting science education among native Alaskan people. Teachers' Domain is a very high-quality digital library of educational resources, including animated tutorials provided by ACRF. The timing of the project coincides with International Polar Year outreach efforts, increasing the potential for the project to reach a broader audience and educate them about climate change processes affecting the Arctic region. An excerpt from the NSF notification states: "Collaboration with the DOE ARM programs (sic) ... has the potential to lead to expansion of the project activities to include other native communities around the world."

\section{ARM Mobile Facility}

The AMF was developed to address science questions beyond those addressed by the fixed measurement sites. The AMF is similar to the fixed ACRF sites in that it contains many of the same instruments and data systems, but is designed to be deployed around the world for campaigns lasting 6-12 months.

The AMF consists of several portable shelters, a baseline suite of instruments, data communications, and data systems. Because deployments may often be associated with experiments from other agencies, it was designed to host instruments other than the baseline collection. Datastreams produced by the AMF are available to the atmospheric community for use in testing and improving parameterizations in global climate models.

Interested? All ACRF capabilities are available to scientists worldwide. Each year, a call for proposals is issued through advertisements in scientific journals and on the ARM website. Lead time for receipt of proposals depends on the complexity of the field campaign. While the ACRF does not provide direct funding for scientific research, it may provide limited funding to assist with logistics, development of datastreams and archiving, and other infrastructure activities associated with using the facility. For more information, see www. arm.gov/acrf/fc.stm.

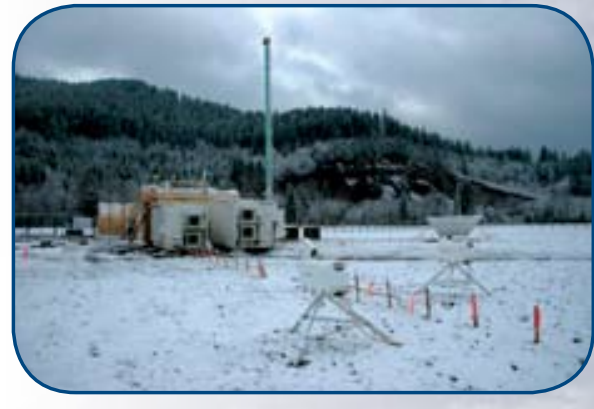

Between March and December 2007, the AMF was deployed in Heselbach, Germany, as an integral component of a long-term precipitation study. In 2008, the AMF will move to China for a study of aerosol indirect effects. 


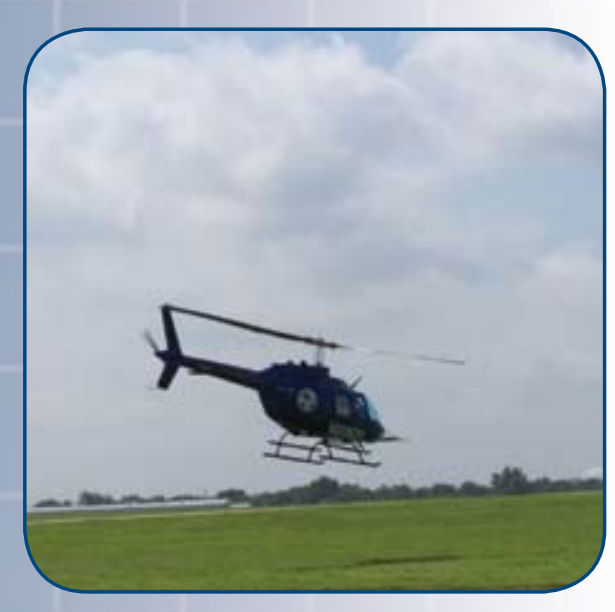

In support of field campaigns that took place at the SGP site in June 2007, the AVP coordinated nine aircraft, ranging from a low-flying helicopter to a stratosphere-cruising ER-2.
Radar Focus Group Looks to the Future. In 2007, the ACRF established a radar focus group to address strategic needs related to the use of radars as a key component of the ACRF instrument suite. With the goal of producing consistently high quality, calibrated radar data, this core group of engineers and scientists will work together to discuss ongoing and future science needs, resolve hardware and software issues, and prioritize algorithm development. Similar focus groups for other major ACRF instrument groupings are planned in the future.

\section{ARM Aerial Vehicles Program}

The ARM Aerial Vehicles Program (AVP) complements the long-term, ground-based measurements of cloud and atmospheric properties by emphasizing instrumented airborne measurement campaigns. To obtain key climate measurements that cannot be made by other means, in situ and remote sensing data acquired from instrumented aircraft at various altitudes provide critical information for studying how clouds interact with solar and infrared radiation.

The AVP has access to a variety of aircraft to address the wide range of measurement requirements associated with atmospheric science issues. Aircraft may be used for short, intensive field campaigns, or for longer-term, regularly scheduled flights. For instance, routine flights by a Cessna over the SGP site support carbon cycle and aerosol research throughout the scientific community.

\section{State-of-the-Art Instrumentation Yields Comprehensive Data Sets}

ARM's approach to instrument development and procurement began with a fundamentally new idea: carry out continuous and simultaneous ground-based observations of the atmospheric column using a suite of passive and active sensors. Previously, most sensors used to investigate atmospheric properties and compositions were strictly research instruments and, in many cases, inadequately understood and calibrated. The goal of ARM's instrument development initiative was to bring existing research instrumentation to the advanced state of development required to allow routine, highly accurate operation in remote areas of the world, and to develop new instrumentation as required.

Because side-by-side comparisons and calibration techniques are critical to instrument understanding, the ACRF routinely sponsors and hosts field campaigns focused on this subject. As a result, the new generation of ground-based, remotesensing instruments include millimeter-wave cloud radar, Raman lidar, infrared interferometers using electronic coolers (instead of cryogens), and updated sky imagers, among others. These instrument arrays represent some of the most sophisticated tools available for conducting atmospheric research.

In addition to the instruments, data on surface and atmospheric properties are also gathered through aircraft, forecast models, satellites, field campaigns, and valueadded processing. Once collected, the information is sent to site data systems and reviewed for quality. Approved data are then stored in the ARM Archive for use by the atmospheric science community.

\section{Science Team Approach Encourages Collaboration}

ARM's Science Team is a unique collaboration of laboratory, university, agency, and private partners from around the globe. From the United States and abroad, cloud and radiation scientists ranging from senior scientists to post-doctoral researchers and students make up the team. Though diverse in geographic location, these 
science representatives provide the most direct channel through which ARM research results can affect development and evaluation of global climate models. Key support is provided by software and hardware engineers who maintain the infrastructure necessary for advancing ARM Science Team research.

Fellowships Promote Use of ARM Data and Achieving Education Goals. To help close the gap between measurements and models, the ARM Program funds fellowships at two key climate modeling centers: NOAA's Geophysical Fluid Dynamics Laboratory and the European Centre for MediumRange Weather Forecasts. The purpose of these fellowships is to enhance the use of ARM data in the development, evaluation, and improvement of physical process parameterizations in climate models. The ARM Program also sponsors an annual fellowship through the American Meteorological Society to help qualified students achieve educational goals in the atmospheric sciences and climate studies.

\section{Working Groups Provide Leadership, Focus on Specific Problems}

To enable focused research on the various pieces of the cloud physics puzzle, the ARM Program divides its research into key areas, or Working Groups. These groups are the principal organizational structure within the ARM Science Team. Each Working Group concentrates on a specific set of issues related to climate modeling. The Working Groups include:

- Aerosols - relate observations of radiative fluxes and radiances to atmospheric aerosols, and use these relationships to develop and test parameterizations to accurately predict atmospheric radiative properties

- Cloud Modeling - relate observations and data analyses to climate model development and evaluation to improve cloud parameterizations in global climate models

- Cloud Properties - develop and implement algorithms that characterize the physical state of the cloudy atmosphere, including cloud occurrence, cloud condensed water amount, and cloud optical properties

- Clouds with Low Optical [Water] Depth - determine the best strategy for measuring clouds with low optical depths and low liquid water paths at ACRF locales

- Radiative Processes - test radiation parameterizations, particularly for cloudy conditions and for solar radiation, at the accuracy required for climate studies.
Enhanced Data Products Provide Added Value. Data are just data until placed into context. ARM researchers work with "science translators" to develop enhanced data (or value-added) products that can be used as important analysis tools. Available at the ARM Archive, examples of high-impact data products developed in 2007 include:

- W-band ARM Cloud Radar Evaluation Product. Using a new algorithm to combine observations from the AMF's 95-GHz W-band ARM Cloud Radar, micropulse lidar, and ceilometer, scientists have produced cloud boundaries and time-height profiles of cloud location, radar moments, and linear depolarization ratio fields for the 2006 AMF deployment in Niamey, Niger. The temporal resolution is 5 seconds, and the vertical resolution is equal to that of the WACR, 42.856 meters.

- Data Quality Assessment for ARM Radiation Data, or QCRad VAP. This product was developed to assess the data quality and enhance data continuity for radiation data collected at all ACRF sites. It uses climatological analyses of surface radiation measurements to define reasonable limits for testing the data for unusual data values. Output files from the QCRad VAP are now the recommended source for all ARM surface radiation measurement data.

- Microwave Radiometer Retrievals of Cloud Liquid Water and Precipitable Water Vapor. A new algorithm developed by ARM scientists utilizes an advanced absorption model and improved retrieval techniques to greatly improve the accuracy of the derived liquid water path retrievals from 2-channel microwave radiometers at the ACRF sites. A total of 18 years of data from six ACRF sites were processed using this new algorithm. 


\section{Oversight Ensures Relevant Science, Promotes Facility Use}

Oversight of the ACRF is provided by the ACRF Program Director. The Program Director routinely conducts programmatic reviews using subcommittees of the DOE Biological and Environmental Research Advisory Committee. In addition, all proposals for using the facility undergo a rigorous review process. The review process has two primary dimensions - a science peer review and a review of costs, logistics, and schedule, performed by the ACRF Infrastructure Management Board (IMB). Reviews are based on a graded approach; proposals of higher cost and greater complexity receive a higher level of scrutiny.

The IMB assesses the availability and resource requirements of the proposed facility usage. The objective of the IMB is to provide fair and equitable distribution of available funds between the fixed-site facility infrastructure costs, field campaigns (also known as intensive operational periods, or IOPs), and special projects. A primary objective of the ACRF is to increase external (non-ARM) use of the facility without inhibiting the achievement of ARM scientific progress. Based on input by the science community, recommendations for future development of the ACRF are developed annually. These recommendations are presented to the ACRF Program Director for consideration and potential inclusion in budget and spending plans.

\section{Global Program Managed by Many}

Eight national laboratories and numerous government agencies, universities, private companies, and foreign organizations are involved in the ARM Program and ACRF. Each entity serves a vital role in managing and conducting the research, operations, and administration of the science program and user facility.

For ARM Program science activities, direction and oversight is the responsibility of DOE Headquarters. A Science Team Executive Committee reviews scientific progress and provides recommendations for future research. Working Group representatives coordinate the ARM research agenda as appropriate. The site infrastructure that enables ARM science is managed through the ACRF.

The ACRF is also directed by DOE Headquarters. An Infrastructure Management Board coordinates the scientific, operational, data, financial, and administrative function of the ACRF. An 11-member Facility Science Board, selected by the ACRF Program Director, serves as an independent review body to ensure appropriate scientific use of the ACRF.

User Facility Fares Well in Review. In May 2007, the DOE Biological and Environmental Research Advisory Committee published findings and recommendations from its assessment of the effectiveness of ACRF as a national scientific user facility. Based on a review of total user requests, the subcommittee concluded that the ACRF was being effectively used by the broader scientific community, not just the ARM Program. They also stated that cost-cutting measures had achieved the desired efficiency goals, but further cuts could impair the facility's operations. The subcommittee reinforced the importance of the scientific impacts of this facility (including publications), and the value it has had for the international research community. The committee's full report is available on the DOE website (www.sc.doe.gov/ober/berac.html). 


\section{Fiscal Year 2007 Budget Summary and User Statistics}

\begin{tabular}{|c|c|}
\hline \multicolumn{2}{|c|}{$\begin{array}{l}\text { Atmospheric Radiation Measurement Program } \\
\qquad \text { FY } 2007 \text { Budget }(\$ K)\end{array}$} \\
\hline Total ARM Program & 49,751 \\
\hline Infrastructure & 34,893 \\
\hline Science & 14,831 \\
\hline
\end{tabular}

User Statistics for the Period of

October 1, 2006 - September 30, 2007

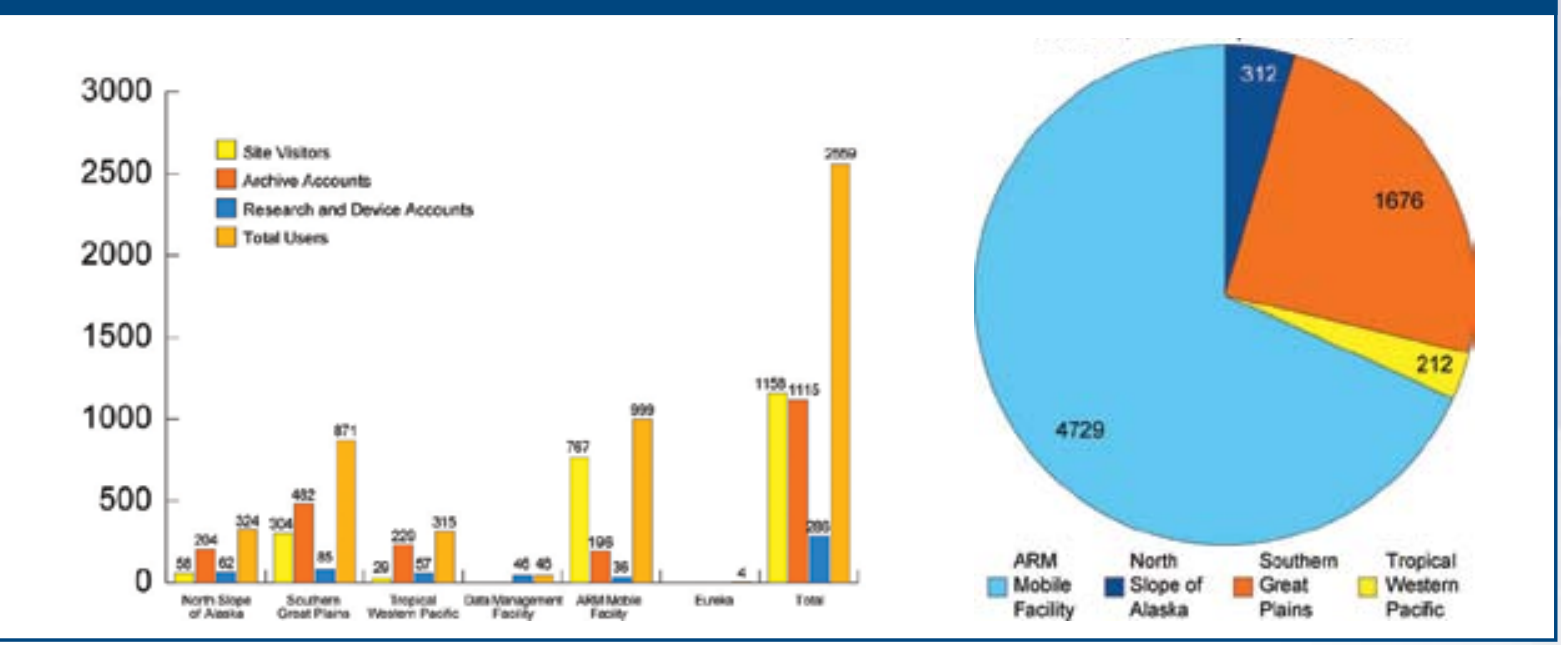

User Summary

Visitor Days by Site

\begin{tabular}{|c|c|c|}
\hline \multicolumn{3}{|c|}{$\begin{array}{c}\text { Operational Statistics for the Period } \\
\text { October 1, 2006 - September 30, 2007 }\end{array}$} \\
\hline & DOAta Availability \\
\hline SITE & 0.90 & ACTUAL \\
\hline NSA & 0.95 & 0.89 \\
\hline SGP & 0.85 & 0.91 \\
\hline TWP & $\mathbf{0 . 9 0}$ & 0.95 \\
\hline Site Average & 0.95 & $\mathbf{0 . 9 2}$ \\
\hline AMF* & & 0.95 \\
\hline
\end{tabular}

${ }^{*}$ Because the AMF is a temporary site, its data availability is based on operational days during field deployment, not 24 hours-a-day/365 days-a-year like the fixed sites. 


\section{Key Accomplishments}

The following pages highlight a selection of research results, field campaigns, and infrastructure achievements from FY 2007 (October 2006 through September 2007). A complete list of FY 2007 field campaigns and publications is provided at the end of this report. More detailed information can be found on the following web pages:

- www.arm.gov/publications/pub_database.stm for Publications

- www.arm.gov/acrflfc.stm for Field Campaigns

- www.arm.gov/acrflupdates.stm for Operations Updates.

\section{Research Highlights}

Members of ARM's Science Team publish an average of 150 refereed journal articles per year, and ARM data are used in many studies published by other scientific organizations. In addition, ARM investigators present their research at key conferences each year. These documented research efforts represent tangible evidence of ARM's contribution to advances in almost all areas of atmospheric radiation and cloud research, and their relevance to climate change modeling efforts.

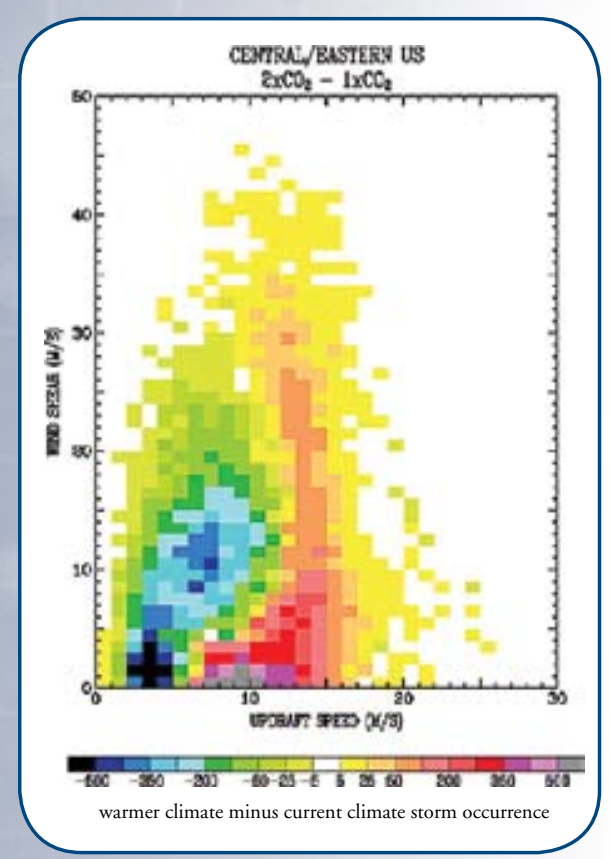

Using the new parameterization for updraft vertical velocities, this figure shows an increase in the occurrence (see color bar) of strong updrafts for given wind shears and decreased occurrence of weak updrafts in the central/eastern United States for March to August in a simulated warmer climate.

\section{Will a Warmer Climate Lead to Stronger Storms?}

While there is some evidence that the intensity of the hurricanes will increase with a warmer climate, predictions for the nature of thunderstorms not associated with hurricanes is lacking. Using a global climate model with a new parameterization for vertical velocities of convective updrafts, ARM scientists examined the intensity of thunderstorms from region to region over ocean and land, and the vertical velocity based on a warmer climate in a simulation of doubled carbon dioxide levels. Their results indicate that a simple estimate of the upward velocity of thunderstorm updrafts reproduces observed land-ocean differences in thunderstorm intensity.

In the simulated warmer climate, updrafts strengthen by about 1 meter per second in the lightning-producing regions of continental thunderstorms, primarily due to an upward shift in the freezing level. For the western United States, drying in the warmer climate reduces the frequency of thunderstorms, but the strongest storms occur 26\% more often. For the central-eastern United States, stronger updrafts combined with weaker change of horizontal winds with height (or wind shear) suggest little change in how often severe storms occur. However, the most severe storms appear to occur more often.

(Reference: Del Genio, AD, M-S Yao, and J Jonas. 2007. "Will moist convection be stronger in a warmer climate?” Geophys. Res. Lett., 34, L16703, doi:10.1029/2007GL030525.)

\section{Improving the Treatment of Clouds in Climate Models}

Clouds with the same microphysical properties (i.e., water content, particle size, thickness, etc.) can have very different impacts on the surface and topof-atmosphere energy budget, depending on their height in the atmosphere. Therefore, it is important for climate models to accurately predict the vertical 
structure of clouds. Using radar and lidar measurements from the TWP site on Manus Island, ARM scientists examined the vertical distribution of clouds and atmospheric radiative heating rates and compared them with results obtained from two climate models: the traditional Community Climate Model (CAM) from National Center for Atmospheric Research; and the relatively new Multiscale Modeling Framework (MMF) from Colorado State University. When compared to the measurements, both models showed significant differences in the vertical profiles of cloud condensate and heating rate profiles, but the MMF method of treating clouds led to improved estimates of the range of variability.

(Reference: McFarlane, SA, JH Mather, and TP Ackerman. 2007. "Analysis of tropical radiative heating profiles: A comparison of models and observations.” J. Geophys. Res., 112, D14218, doi:10.1029/ 2006JD008290.)

\section{Long-Term Data Set Improves Understanding of Impact of Vertical Location of Clouds on Climate}

Long-term measurements of cloud properties not only help scientists to understand their behavior and impacts on atmospheric radiation and climate, but also to evaluate and improve climate models. Multiyear measurements from the SGP site show that cloud occurrence at this mid-latitude site is dominated in the upper troposphere ( $9-11$ kilometers altitude) and in the lower atmosphere's boundary layer (up to 1 kilometer above the surface). Upper tropospheric cloud layers dominate the heating of the troposphere, while lower level clouds provide a largely counterbalancing cooling influence. The combination of these two cloud types results in little net atmospheric cloud radiative effect; however, the displacement of the heating center aloft and cooling center below in the troposphere tends to stabilize temperature profiles in a time-averaged sense.

The vertical distribution of heating and cooling demonstrates a strong seasonal dependence, with the heating center migrating toward higher altitudes as the summer troposphere deepens. Remarkably, however, the seasonal variation in infrared heating of the troposphere is not evident in the annual cycle of top-of-atmosphere infrared radiative effect, and is only weakly evident in the seasonal cycle of the radiative effect at the surface. The ability to document vertical profiles of clouds and associated radiative heating/cooling within the atmospheric column above the SGP site provides a unique and valuable data set that reveals behavior not evident at the top or bottom of the column. Composited information from 8 years at the SGP site gives modelers a powerful data set for evaluating climate model simulations of seasonal cloud and radiation variation under continental, mid-latitude conditions.

(Reference: Mace, GG, and S Benson. 2007. "The vertical distribution of cloud radiative forcing at the SGP ARM Climate Research Facility as revealed by 8 -years of continuous data." Journal of Climate, accepted.)

Cloud occurrence (a), coverage (b), radiative forcing (c-e), and radiation effects $(f-h)$ over a composite annual cycle are derived by averaging all observations collected during a particular month for 8 years at the SGP site. Such monthly composites allow scientists to study seasonal behavior of clouds and radiation under regional conditions.

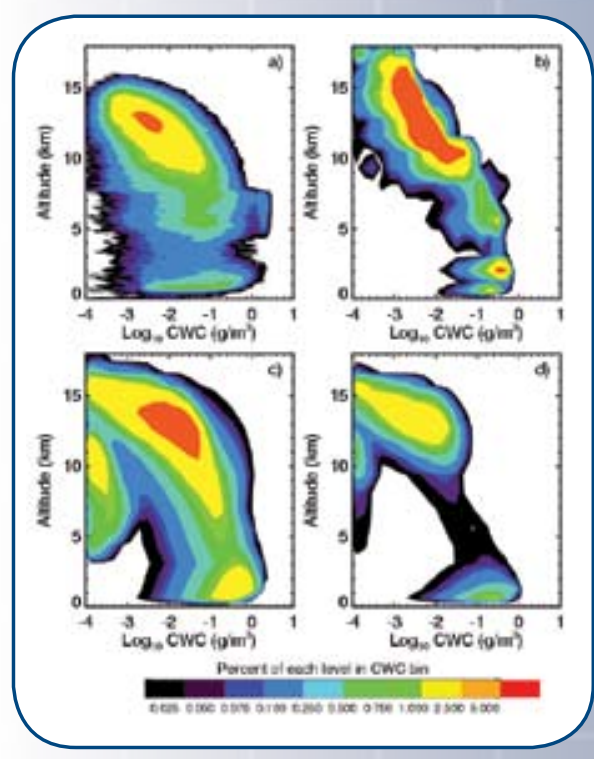

Comparison of the distributions of cloud condensate for the ACRF TWP site in Manus using (a) retrievals from the ACRF remote sensors, (b) the CAM, (c) all MMF columns, and (d) MMF columns that do not contain precipitation. Note that the ARM observations do not include precipitation. The CAM produces a very narrow range of ice water content in the upper atmosphere compared to the ARM and MMF distributions.

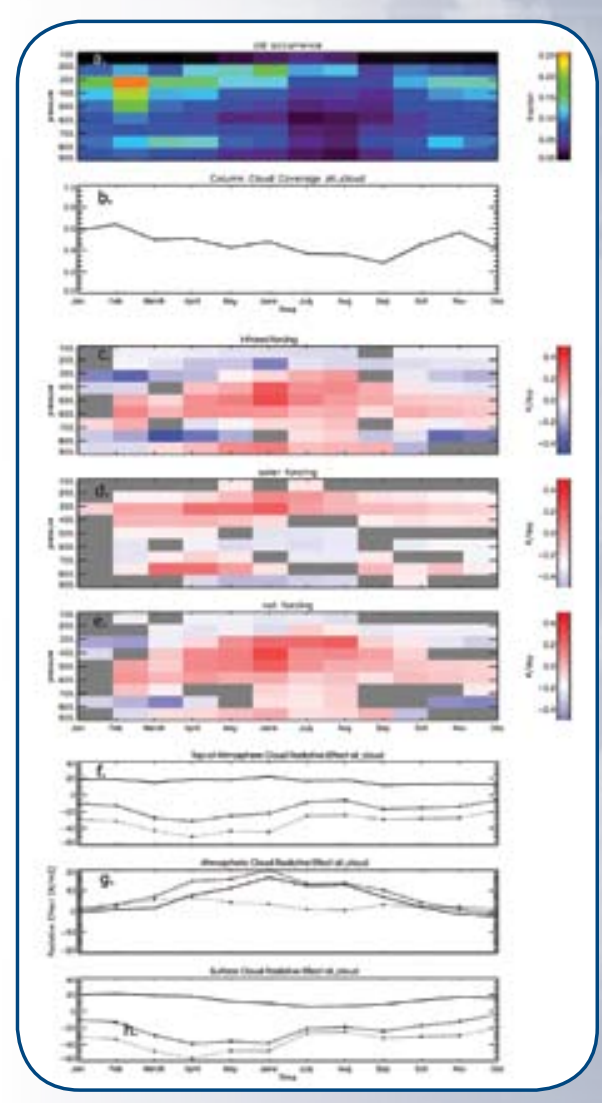




\section{Arctic Cloud Study Confirms Question About Ice Crystal Formation}

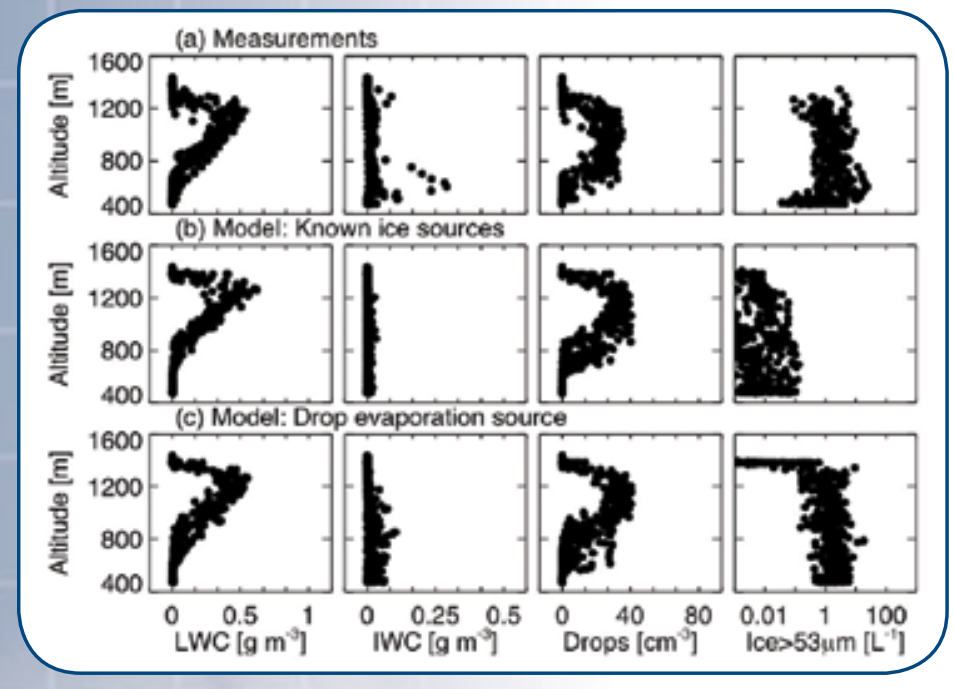

Model results with all known ice sources underestimate measured ice concentrations by two orders of magnitude (a versus b), but hypothesized ice sources related to drop evaporation could explain the measurements (c). Additional measurements are required to either confirm or rule out such sources.
Low-level mixed-phase (liquid and ice) clouds occur routinely during all seasons in the Arctic. These clouds play a crucial role in the surface energy budget of the Arctic. Arctic mixed-phase clouds have been observed to persist for days, even though these liquid-topped clouds are continually precipitating ice. Mixed-phase cloud processes are poorly understood and thus the processes that govern cloud longevity remain uncertain. Using measurements from the Mixed-Phase Arctic Cloud Experiment (M-PACE) in October 2004, ARM scientists performed computationally intensive largeeddy simulations, which incorporate virtually everything currently known about the processes controlling the evolution of liquid and ice within such clouds. Results indicate that known ice formation mechanisms (or sources of cloud ice) produce two orders of magnitude less ice than measured during M-PACE.

These results are consistent with decades of past literature, but demonstrate the governing processes with a modern data set and modern computational techniques. The research team tested several ice formation mechanisms and found that those related to drop evaporation (first hypothesized in the 1950s and only sparsely studied since) show significant promise for explaining the M-PACE measurements, although uncertainties remain. These results indicate that current representations of ice microphysics in large-scale numerical weather prediction and global climate models may not represent some of the dominant ice formation mechanisms.
ARM Researchers Achieve Tropospheric Trifecta. The February 2007 issue of the Bulletin of the American Meteorological Society, or BAMS, featured three ARM research papers. Two of the articles-Turner et. al. and Comstock et. al.-Cover studies of retrieval algorithms used to characterize the microphysical properties of thin liquid water clouds and upper tropospheric ice clouds, respectively. The third article, Verlinde et. al., discusses the scientific objectives and emerging results of the Mixed-Phase Arctic Cloud Experiment, conducted in October 2004.
(References: McFarquhar, GM, G Zhang, MR Poellot, GL Kok, R McCoy, T Tooman, A Fridlind, and AJ Heymsfield. 2007. "Ice properties of single layer stratocumulus during the Mixed-Phase Arctic Cloud Experiment (M-PACE): Part I. Observations." J. Geophys. Res., in press.

Fridlind, AM, AS Ackerman, GM McFarquhar, G Zhang, MR Poellot, PJ DeMott, AJ Prenni, and AJ Heymsfield. 2007. Ice properties of single-layer stratocumulus during the Mixed-Phase Arctic Cloud Experiment (M-PACE): Part II, Model results." J. Geophys. Res., in press.

Verlinde, J, JY Harrington, GM McFarquhar, VT Yannuzzi, A Avramov, S Greenberg, N Johnson, G Zhang, MR Poellot, JH Mather, DD Turner, EW Eloranta, BD Zak, AJ Prenni, JS Daniel, GL Kok, DC Tobin, R Holz, K Sassen, D Spangenberg, P Minnis, TP Tooman, MD Ivey, SJ Richardson, CP Bahrmann, M Shupe, PJ DeMott, AJ Heymsfield, and R Schofield. 2007. "The Mixed-Phase Arctic Cloud Experiment." Bull. Amer. Meteorol. Soc., 88, 205-221.

Prenni, AJ, JY Harrington, M Tjernström, PJ DeMott, A Avramov, CN Long, SM Kreidenweis, PQ Olsson, and J Verlinde. 2007. "Can ice-nucleating aerosols affect Arctic seasonal climate?” Bull. Amer. Meteorol. Soc, Vol. 88, Iss. 4; pg. 541-550.) 


\section{Advances in Global Weather Forecasting}

One of the world's foremost weather forecast models from the European Centre for Medium-Range Weather Forecasts (ECMWF) is showing dramatic improvements thanks to the pairing of two recent advancements in the representation of radiative transfer in global weather and climate models. Developed with funding from the ARM Program, the new components simulate the absorption and scattering of sunlight in the atmosphere and better represent small-scale cloud variability. The first component is a rapid radiative transfer model called RRTMG, which is a version of the column model RRTM. The second component, "Monte Carlo Independent Column Approximation" or McICA, is a statistical technique for representing the interaction between radiation and small-scale variations in cloud geometry and cloud properties.

When using the new components in the ECMWF model, zonally averaged temperature biases were reduced through much of the lower atmosphere. Better agreement with observations is also seen in 10-day forecasts and, remarkably, the better agreement persists for the entire 10-day cycle of forecasts. Improvements in the simulated temperature structure also affect other aspects of the simulation. For instance, the new configuration has curbed the model's previous tendency to over-predict convective thunderstorms over the ocean relative to those over nearby land areas. The new components provide the flexibility necessary to incorporate future advances in cloud physics resulting from the ARM Program and other research organizations.

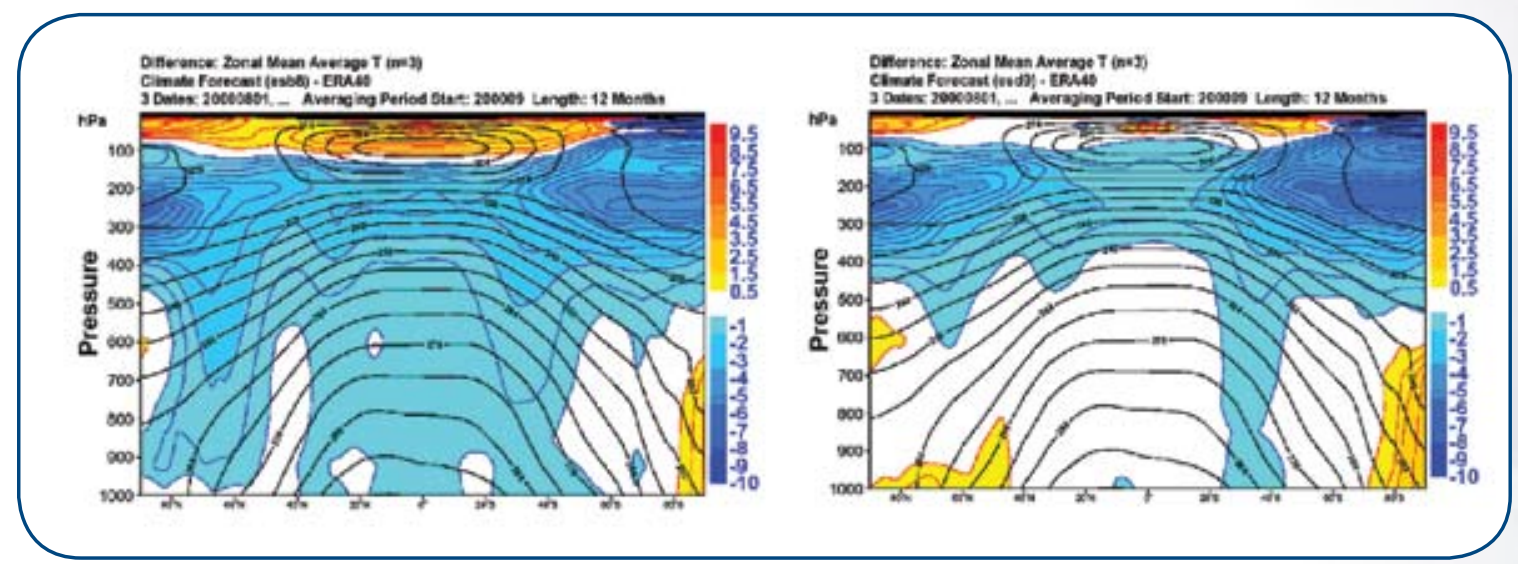

In the left panel, black contours are from the ECMWF reanalysis data set ERA-40 for mean-annual, zonallyaveraged temperatures, while colored contours correspond to differences between ERA-40 and the ECMWF model without the new radiation components. Using the same variables in the right panel, the colored contours correspond to differences between ERA-40 and the ECMWF model with the new components.

(Reference: Morcrette, J-J, HW Barker, JNS Cole, MJ Iacono, and R Pincus. 2007. "Impact of a new radiation package, McRad, in the ECMWF Integrated Forecasting System.” Mon. Wea. Rev., submitted.)

\section{Tropical Cloud Study Yielding Insights About Cloud Ice and Radiative Forcing}

Results are starting to be published from the Tropical Warm Pool-International Cloud Experiment (TWP-ICE) conducted in 2006 in the vicinity of Darwin, Australia (see acrf_campaign.arm.gov/twpice). The purpose of the experiment was to examine convective cloud systems from their initial formation through to their decaying stages, and to measure the accompanying thin high-level cirrus and their 


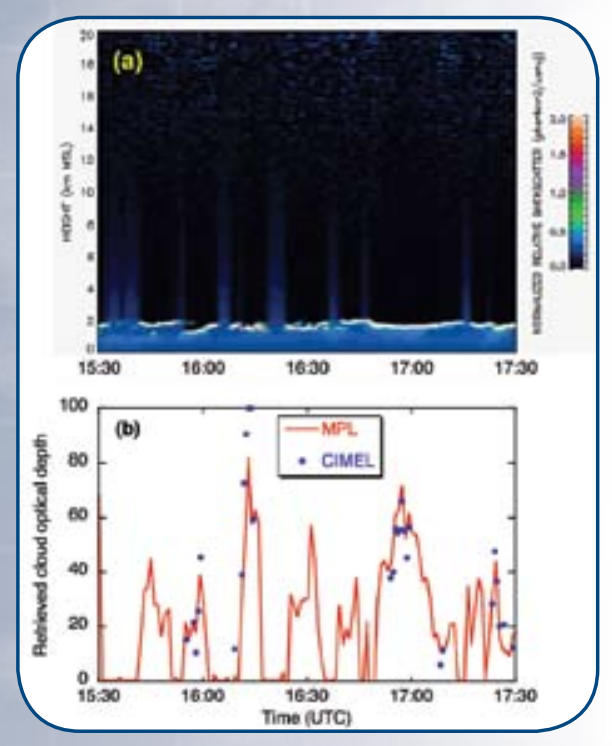

The upper figure shows a micropulse lidar (MPL) backscatter vertical profile during a period of patchy cloud cover on October 29, 2005. The lower figure shows the time series of corresponding cloud optical depth retrieved from the MPL and from a collocated AERONET Cimel sunphotometer operated in "cloud mode." Differences in retrievals between the lidar and Cimel are partly due to different fields of view in the two instruments and slightly different locations. impact on the environment. The experiment gathered an unprecedented range of in-situ and remotely sensed observations to help improve the most poorly known parts of cloud resolving models.

Early publication results examined measurements of the concentrations of small ice crystals between 3 and 50 micrometers (see article referenced below). Knowledge of small crystal properties is important in order to represent cloud-radiative feedbacks in climate models and the study provided new insights for improving measurement strategies related to these properties. Using the TWP-ICE data, ARM scientists have also compiled large-scale forcing and evaluation data that are critical to singlecolumn model and cloud-resolving model studies. The analysis products include both the large-scale forcing terms and the evaluation fields, which can be used for driving both types of models and validating their simulations.

(Reference: McFarquhar, GM, J Um, M Freer, D Baumgardner, GL Kok, and G Mace. 2007. "Importance of small crystals to cirrus properties: Observations from the Tropical Warm Pool International Cloud Experiment (TWP-ICE).” Geophys. Res. Lett., 34, L13803, doi:10.1029/ 2007GL029865.)

\section{Using Lidars to Retrieve Optical Depth of Thick Clouds}

Surface-based pulsed lidars are increasingly used to retrieve vertical distributions of cloud and aerosol layers. Because the active laser pulse becomes attenuated very quickly in thick clouds, lidar cloud retrievals (other than cloud-base altitude) are widely thought to be limited to optically thin clouds. However, recent ARM research demonstrated that lidars can retrieve optical depths of thick clouds as well. This new finding is achieved by using the lidar's solar background measurement as a signal.

Lidars receive solar background light in addition to backscattered laser light. These measured photon counts are typically converted to attenuated backscatter profiles, while the solar background light is treated as "noise" and removed. However, the solar background can be used to retrieve optical depth. This idea was tested for various cloud cases and locations.

Validations against competing instruments show that retrieved cloud optical depths agree within $10-15 \%$ for cases of overcast stratus and broken clouds. Thus, for broken clouds, using a lidar in both passive and active mode, one can retrieve the aerosol properties in clear-sky periods and also the optical depth of clouds in cloudy periods. This makes possible the study of aerosol-cloud interactions with a single instrument. This new method also provides an excellent opportunity to explore the relationship between cloud-base height and optical depth for all clouds. Such relationships are important for understanding the overall laws of cloud behavior and for parameterizing clouds in climate models.

(Reference: Chiu, JC, A Marshak, WJ Wiscombe, SC Valencia, and EJ Welton. 2007. "Cloud optical depth retrievals from solar background "signal" of micropulse lidars." IEEE Geosci. Remote Sens. Lett., 4(3), 456-460, doi:10.1109/LGRS.2007.896722.) 


\section{Featured Field Campaigns}

\section{Conditions Range from Classic to Extreme During Continental Field Campaign}

Early summer in Oklahoma normally means extended periods of hot, sunny weather mixed with brief, intense rain showers. Such were the conditions anticipated by the team of researchers involved in the Cloud and Land Surface Interaction Campaign, or CLASIC. For 3 weeks in June at the SGP site, measurements were obtained on the ground and in the air to evaluate changes in clouds and atmospheric structure-key elements of regional climate systems. Scientists involved in CLASIC were specifically interested in the influence of land surface processes on the evolution of cumulus convection, especially the stages leading from cumulus humilis (fair weather clouds) to cumulus congestus (storm clouds).

A total of 85 research flights took place in June among the seven aircraft involved in CLASIC. A helicopter flew as low as 9 meters above ground, and at the other extreme, an ER-2 flew in the stratosphere around 16,000 meters. The other five aircraft - two Twin Otters, a Jetstream-31, a P-3, and the ACRF's Cessna 206-flew between these, taking measurements of clouds and aerosol properties just below, in, and above the clouds. Two additional aircraft—a Gulfstream 1 and a Beechcraft King Air 200_-shared airspace with CLASIC for a complementary field campaign called the Cumulus Humilis Aerosol Processing Study. Sponsored by the DOE Atmospheric Science Program, this campaign occurred at the same time and in the same vicinity as CLASIC. All nine aircraft were coordinated by the ARM Aerial Vehicles Program and research flights were timed to coincide with satellite overpasses when possible.

Enhanced surface instrumentation at the SGP Central Facility and CLASIC supersites_Little Washita/Fort Cobb and Okmulgee-obtained information about surface and atmospheric energy and carbon exchange. To help characterize the large-scale environment, intensive weather balloon launches-8-per-day for 10 consecutive days at the four boundary sites - supplemented the routine, 4-per-day launches at the SGP Central Facility. Also, several carbon flux towers were added at the supersites, and two prototype scanning radar systems were deployed; one near the SGP Central Facility and another to the south. These radars include additional frequencies and advanced signal processing techniques that enable cloud microphysical processes to be observed with a new level of detail.

The campaign featured concurrent contributions from the National Aeronautics and Space Administration, National Oceanic and Atmospheric Administration, and United States Department of Agriculture. Timed to coincide with the seasonal transition into the summer growing season, these participants extended CLASIC's spatial domain to capture regional processes. They also expanded the observational framework through additional space-based observations, aircraft campaigns, surface and subsurface hydrologic components, isotopic measurements, carbon dioxide fluxes, and associated modeling. Because of this cross-disciplinary interagency involvement, the CLASIC research effort was identified as the core component of a 2007 priority for the interagency Water Cycle Working Group of the U.S. Climate Change Science Program.

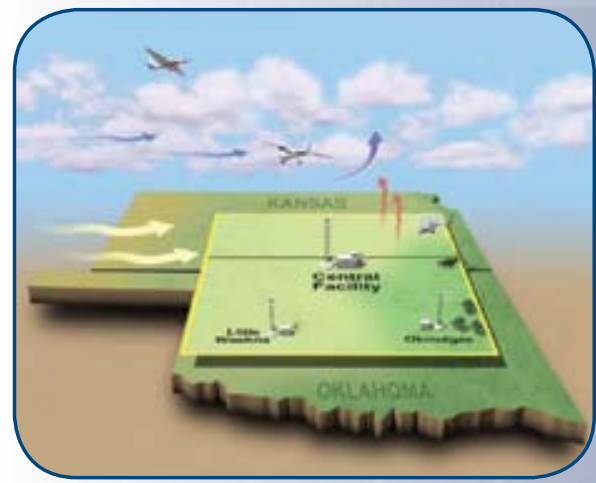

During CLASIC, researchers used seven aircraft and enhanced instrumentation at key locations throughout the SGP site to obtain data about regional land surface changes that impact surface reflectivity, temperature, evapotranspiration, energy balance, and cloud development and characteristics.

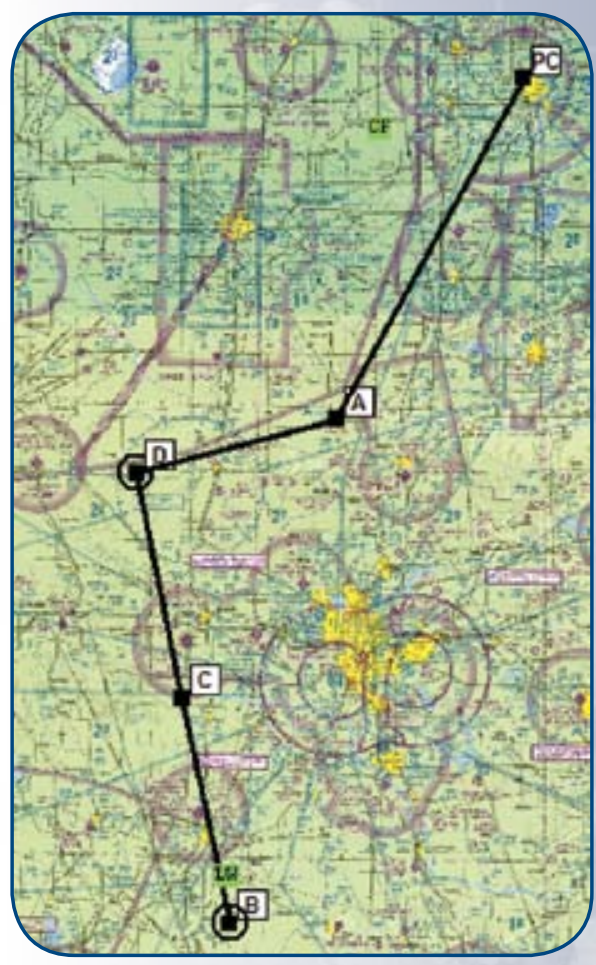

On June 19, five aircraft flew in stacked formation beneath the A-Train satellite ground track $(B, C, D)$, converging over the target $(C)$.

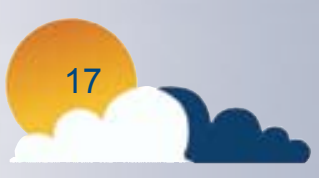




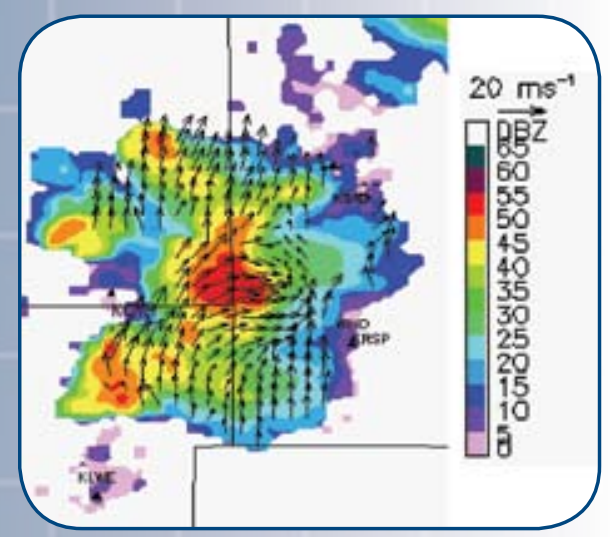

Surface enhancements at the SGP site allowed the team to capture both the normal convective systems and the unusual rainy period with an unprecedented collection of instruments. A network of four scanning radars captured a complex of thunderstorms in the southern portion of the site on June 10, 2007. The arrows show wind direction, while the colors indicate the intensity of the convective cells.

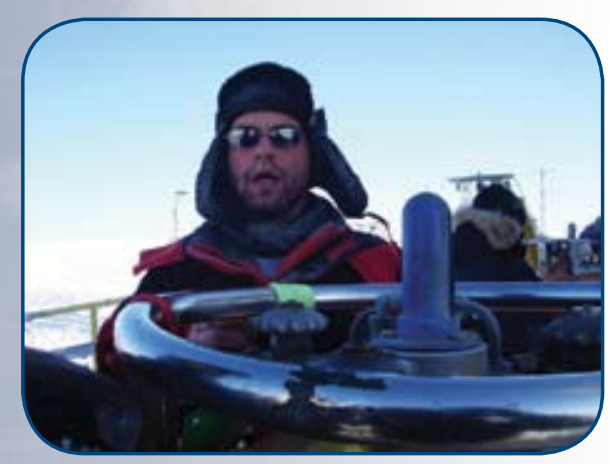

Dr. Dave Turner, co-leader of the field campaign, works on a dewar containing liquid helium, a cryogenic liquid required by the TAFTS instrument to cool its detectors. This greatly improves the signal-to-noise ratio of the observations.
Results: As luck would have it, Oklahoma endured unprecedented amounts of rainfall in June, shattering a 70-year old precipitation record. Fortunately, classic early-to-mid-June conditions prior to the onset of the heavy rains provided plenty of opportunities to obtain surface and cloud property data directly related to the campaign's scientific objectives. These included several coordinated A-Train satellite overpass validation missions involving all seven CLASIC aircraft and numerous stacked flights over the SGP site.

Two satellite overpass validation missions occurred on June 12 and 19 under the desired conditions. Broken clouds on June 12 presented an ideal fair weather cumulus case. Several aircraft flew over each of the CLASIC supersites throughout the day, in addition to the afternoon satellite validation mission and an SGP Central Facility overpass. On June 19, five aircraft flew in a stacked formation within 305 meters of the A-Train satellite ground track, converging at various altitudes above the target amid shallow broken clouds at the time of the overpass. In addition, two aircraft completed simultaneous survey patterns over the CLASIC domain and two other aircraft completed vertical profiles over the SGP Central Facility and Little Washita surface sites.

Extreme weather near the end of the campaign provided rare and valuable data sets for analysis. An unexpected data set resulting from the monsoon-like conditions was obtained on June 28, when the ER-2 aircraft flew above the Twin Otter at the edge of a "tropical" squall line, which deepened throughout the flight. Data from a corresponding satellite overpass will allow ARM scientists to evaluate the effectiveness of the various radar retrievals under these types of conditions. And on the last day of the campaign, the CIRPAS Twin Otter obtained a rare data set of a very clean atmosphere to contrast with the more normal aerosol-laden conditions in the area during this time of the year. The wide array of surface and airborne data obtained during CLASIC will be analyzed by climate scientists for years to come.

\section{Arctic Winter Provides Window of Opportunity to Improve Climate Models}

For 3 weeks spanning February and March 2007, scientists used two state-of-theart infrared Fourier transform spectrometers-highly sophisticated instruments that measure light intensity with high spectral resolution-to obtain atmospheric measurements in the far infrared portion, or band, of the electromagnetic spectrum. Information gained from the Radiative Heating in Underexplored Bands Campaign at the ACRF site in Barrow, Alaska, will provide the first simultaneous high-resolution dataset of Arctic clear-sky and cirrus cloud properties in the far infrared.

Visible light, or what we see as the color band, occurs between 0.4 and 0.7 microns; the far-infrared band occurs at wavelengths longer than 15 microns. Absorption of radiation by water vapor in the far-infrared band is responsible for the majority of the cooling that occurs in the middle and upper troposphere-between 6.4 and 14.4 kilometers above the Earth's surface. Accurate measurements in the far-infrared have been limited by the lack of accurate instrumentation to measure these radiances, plus the fact that the far-infrared "window" is "closed" at most surface observation locations. This is due to strong absorption by water vapor, which 
makes the atmosphere look opaque in the far infrared. However, this band becomes semi-transparent in very low water vapor conditions. The far-infrared band is referred to as the "Arctic window" because it "opens up" in the low water vapor conditions that are prevalent at high latitudes.

Using an Extended Range Atmospheric Emitted Radiance Interferometer (AERIER), developed through the ARM Program, and the Tropospheric Airborne Fourier Transform Spectrometer (TAFTS) from Imperial College in London, scientists collected critical data from the far infrared region of the atmosphere. In addition to the infrared interferometers, the following three state-of-the-art millimeter wavelength radiometers were used to obtain measurements of the total amount of water vapor in the atmosphere.

- The G-band Vapor Radiometer (GVR) measures sky radiances from four double sideband channels centered at $\pm 1, \pm 3, \pm 7$, and $\pm 14 \mathrm{GHz}$ around the $183.31 \mathrm{GHz}$ water vapor line.

- The Ground-based Scanning Radiometer (GSR) is a 29-channel scanning radiometer that measures radiance in the frequency band from 50 to $400 \mathrm{GHz}$, providing information about water vapor, temperature, and clouds.

- The third and newest radiometer, called a MP183A radiometer, provides radiometric observations at 15 frequencies ranging from 170 to $183.3 \mathrm{GHz}$.

The 183.3-GHz radiometers are part of a new generation of ground-based instruments designed to measure sky radiances in a frequency region of the microwave spectrum that is highly sensitive to the presence of very small amounts of water vapor. Therefore, these instruments are especially useful during the dry Arctic winter, when precipitable water vapor amounts are often less than 5 millimeters. Routine measurements from a host of other instruments at the ACRF site in Barrow will supplement the data set.

Results: While several of the data sets from the guest instruments (such as the TAFTS and GSR) are still being calibrated, several important results have already come from analysis of this data set. The main objective of the $183-\mathrm{GHz}$ microwave radiometers is to provide accurate retrievals of precipitable water vapor (or the total amount of water vapor in the column of air above the site); however, this requires that the spectroscopic information — such as strength, width, and other parameters-of the water vapor line at $183.31 \mathrm{GHz}$ are correct. Data from this experiment are being used to improve the accuracy of the width of this water vapor line, and more importantly, to quantify the uncertainty in the spectroscopic parameters.

Also, data from the AERI-ER have allowed scientists to evaluate a portion of the far-infrared spectral band, as well as the adequacy and uncertainty in the water vapor retrievals from the $183-\mathrm{GHz}$ radiometers. These results demonstrate that widths of some of the water vapor lines in the far infrared are in signficant error, and these have been improved. A paper on these results is being prepared.

"The instruments all operated well, and we have perhaps the best data set of observations of the $183 \mathrm{GHz}$ water vapor line ever made," said Dr. Dave Turner from the University of Wisconsin-Madison, and one of two lead scientists for the experiment. "This was aided by extremely cooperative weather during the campaign, with below-normal surface temperatures resulting in lower-than-normal amounts of precipitable water vapor and a nice, open Arctic window in which to obtain our observations."
Measurements from the GVR (foreground) and the MP183A (background left) allow scientists to determine the amount of water vapor in the column of air above the site during the campaign.

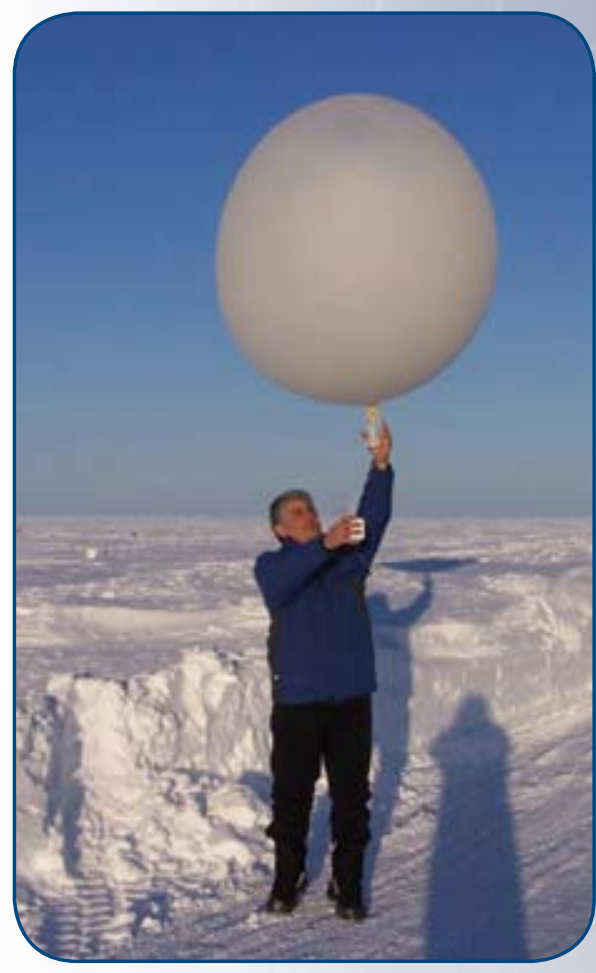

Dr. Eli Mlawer, co-leader of the field campaign, launches a radiosonde from the ACRF site in Barrow. Extra sonde launches during the 3-week experiment doubled the number of clear, dry cases in the ARM Archive, significantly increasing the statistics available for analysis. 


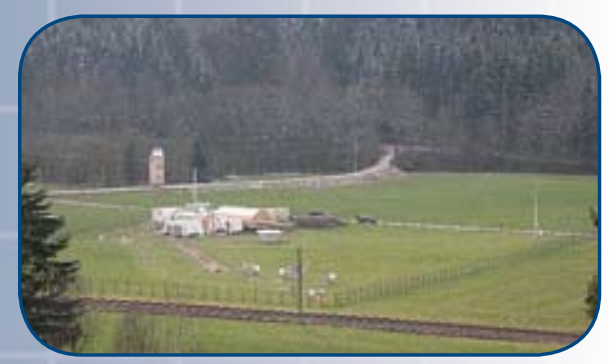

Joining the AMF instrument suite in Heselbach, Germany, scientific collaborators brought in dozens of additional guest instruments to conduct separate but related field campaigns during the deployment.

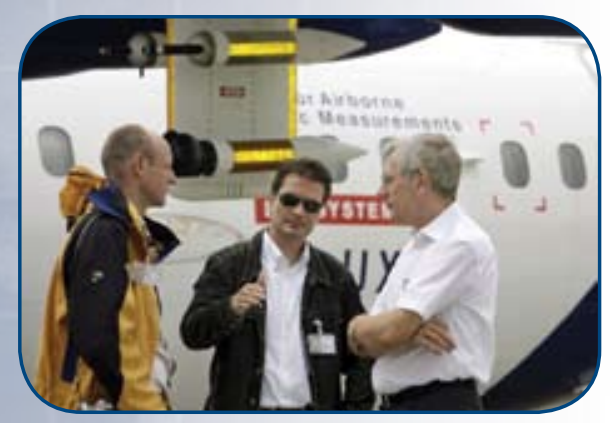

In front of the research aircraft BAE 146 from the United Kingdom, COPS science team members. Dr. Christoph Kottmeier (right) and Dr. Volker Wulfmeyer (center) discuss mission planning with COPS Coordinator Dr. Andreas Behrendt. Instrument inlets for measurements of aerosol and cloud microphysics are visible behind the group.

\section{Research in Germany's Black Forest Will Improve Precipitation Forecasts}

From March through December 2007, the AMF was an integral part of a research and development project aimed at improving precipitation forecasting in convective conditions. Located in the village of Heselbach in the Black Forest region of Germany, the AMF was one of several "supersites" obtaining atmospheric measurements for the Convective and Orographically Induced Precipitation Study, or COPS. Orographic precipitation is the result of atmospheric uplift and subsequent rainfall induced by mountainous terrain. Because orographic rain forms so differently than "regular" rain, scientists have a difficult time predicting it, which has led to unexpected and catastrophic storms and flooding in Germany.

Measurements obtained by the AMF during the COPS field campaign encompassed the entire life cycle of precipitation-from pre-convective conditions to the development of clouds, followed by the onset, development, and organization of precipitation. Installation and continuous operation of instrument networks to measure soil moisture, turbulence, and energy balance, were supplemented by more than 1300 additional soundings and global positioning system networks. Remotesensing systems along a transect of five supersites - particularly the AMF, which was combined with additional in situ as well as passive and active remote-sensing systems - observed convergence lines in relatively homogeneous areas during preconvective conditions. This phenomemon remains elusive, but its understanding is essential for correct modeling of convection initiation. The combination of scanning passive and active remote sensors deployed for COPS also provided the first $2 \mathrm{D}$ and $3 \mathrm{D}$ measurements of atmospheric variables.

Scientists at the University of Hohenheim are leading the study, which was initiated and funded by the program "Quantitative Precipitation Forecasting" of the German Research Foundation. The campaign is also being coordinated with additional programs within the World Weather Research Program established by the World Meteorological Organization. These combined efforts represent one of the largest international weather research efforts performed to date in Europe.

The unique collaboration with the international mesoscale modeling community is a particularly notable feature of the COPS campaign. These collaborators provided the new generation of mesoscale ensemble forecast systems and deterministic convection permitting models running in real time for mission planning. Rapid scanning intervals by the Meteosat satellite and real-time application of special retrievals also aided mission planning and model evaluation. During the primary period of the campaign, flights by 10 airborne platforms were coordinated in one of the most crowded air traffic areas in Europe, collecting more than 400 hours of data. During several other intensive operational periods (IOPs), the German Falcon aircraft was operated in critical upstream areas identified by targeting efforts from another European regional campaign. The IOPs covered a variety of different forcing mechanisms with respect to the initiation of convection from air mass convection to weakly and strongly forced conditions, including passages and transformation of mesoscale convective systems and fronts. 
"The AMF data set embedded in the European summer experiments is a treasure for atmospheric science," stated Dr. Volker Wulfmeyer, professor at the University of Hohenheim and chair of the COPS International Science Steering Committee. "It will be essential for improving the quality of precipitation forecasts in complex terrain. This is a prerequisite for extending the lead time of flash-flood forecasting, which is of great economic and societal relevance."

Results: The performance of the mesoscale ensemble can be studied in detail with the data sets obtained during COPS. One of the most dramatic cases for future study occurred in early August, when a Saharan dust outbreak reached southern France. Strengthening of the atmospheric circulation initiated the development of a mesoscale convective system (MCS) in the dust layer, and the MCS propagated northeastwards towards the COPS domain. Ahead of the MCS, the humid dust layer was advected into the COPS domain.

On the morning of August 2, the MCS with deep convective cells passed over the AMF site. During the afternoon and the evening, at the back side of the MCS, a colder and rather unstable air mass was advected in the COPS domain, forming another convective cell. This combination of events presents a very interesting case for studying initiation of convection and aerosol-cloud-precipitation microphysics. Key data were provided by the AMF's 95-GHz W-band ARM cloud radar, or WACR, which measured the reflectivity of the convective system with great detail. Data from the WACR will be used with measurements from other remote sensors to retrieve microphysical properties of cloud particles during this event.

Based on observations of the development of clouds and precipitation from Saharan dust outbreaks that occurred several times during the COPS period, scientists have a unique opportunity to study aerosolcloud-precipitation microphysics in great detail. They are also studying parameterizations of the atmospheric boundary layer, convection, and cloud microphysics with $4 \mathrm{D}$ synergetic observations, as well as the performance of an ensemble of convection permitting models, which can be evaluated in detail for the first time. Initial results indicated better performance with respect to the prediction of convection initiation and precipitation in complex terrain. Particularly, severe precipitation events, which led to flooding in Switzerland and southern Germany during COPS, will be the focus of ensuing research.

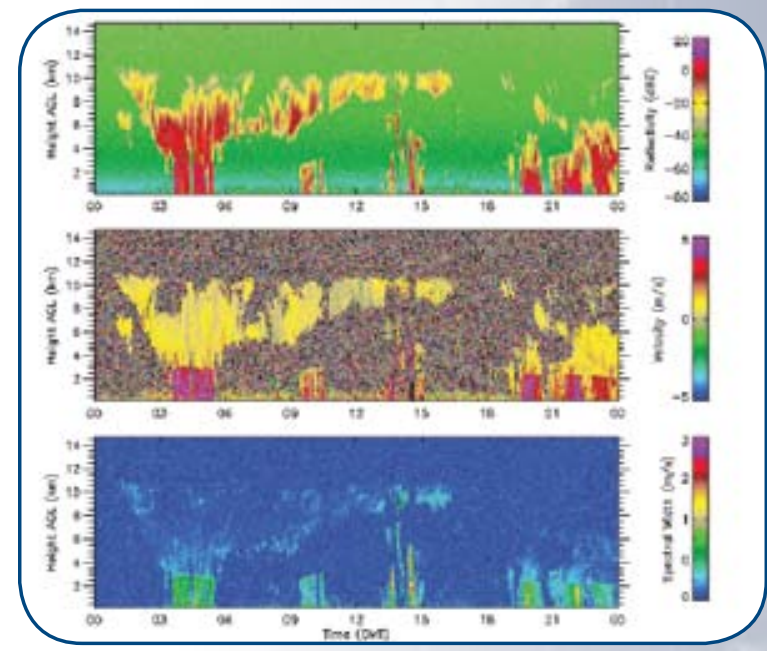

Measurements obtained by the WACR on August 2, 2007, show the radar reflectivity (upper panel); vertical velocity of cloud particles and hydrometeors, with a sharp gradient at about 2 kilometers indicating the melting layer (middle panel); and the spectral width of vertical velocity, which is a measure of turbulent activity (bottom panel). 


\section{Infrastructure Achievements}

\section{Site Operations}

\section{Records Set Again; Users Easier to Identify}

In the third quarter of FY 2007, a second straight record-high number of users (1092) and a new record for visitor days (2083) were reported by ACRF. The statistics also indicated a notable increase in non-ARM-funded users at the ARM Mobile Facility deployment site in Germany, as well as large increases in total visitor days there and at the SGP site. To aid in reporting these important user facility statistics, ACRF staff at the External Data Center and the ARM Archive worked closely together to establish a process to determine the number of users by ACRF site and by category-site visitor or data user.

The list of site visitors was determined using the ACRF Site Access Request System, which provides both advance notice of onsite visits to site managers to coordinate needed support, as well as a mechanism for requesting and managing access to site network and computer resources. The ARM Archive user statistics then required a match-up in the ARM People Database before determining whether a user was funded through the ARM Program or an external source. Membership in one of the variety of groupings maintained in the People Database indicated whether the user was funded by the ARM Program.

\section{Improved Instrument Calibration Capabilities Benefit All Sites, Users}

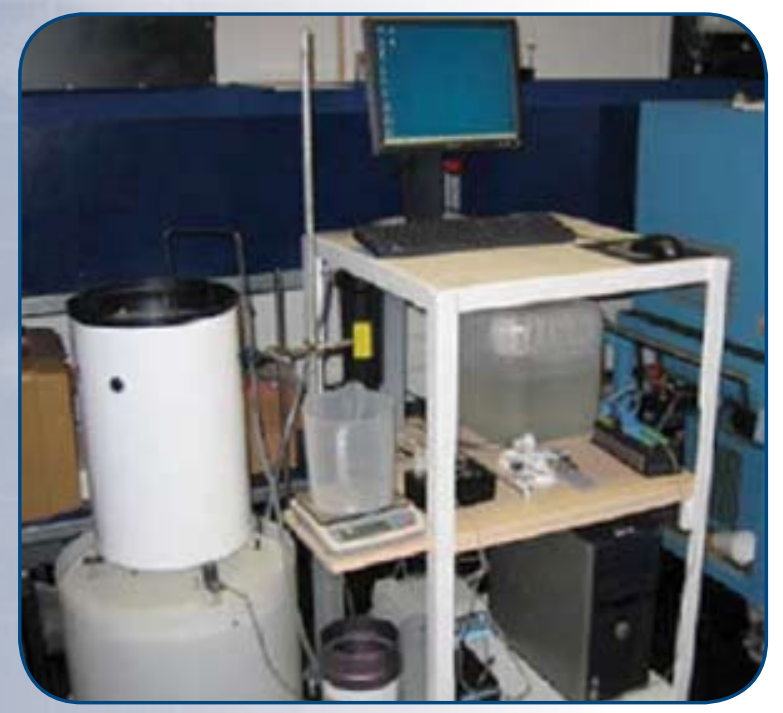

To ensure that ACRF precipitation measurements are as accurate as possible, rain gauges (white cylinder above left) at the SGP site are inspected every 2 weeks, are statically calibrated in the field every 6 months, and will now be dynamically calibrated on an annual basis using the system shown here.
The ACRF fills a unique position in the scientific community by obtaining long-term continuous measurements of cloud and radiation properties critical to climate modeling. Central to this mission is the ability to maintain and quickly repair instruments, as well as providing integrated instrument calibration processes to ensure ACRF provides high-quality data products. During its past 15 years of operations, the SGP site has developed many onsite repair and calibration capabilities. This has led to increased efficiencies and cost savings that benefit not just the SGP site and its users, but the other ACRF sites as well. In the past year, enhancements to various components of the site's Radiometer Calibration Facility further increased its ability to provide timely and accurate data to the scientific user community.

In 2007, a dynamic rain gauge calibration procedure was implemented that compares known "rainfall rates" generated by computer-controlled equipment to rates measured by the gauge being calibrated. Differences are then accounted for in the rain gauge data processing. The previous manual process of dripping a known amount of water into the gauge and reading the amount of water measured did not take into account errors that might occur during a heavy rainfall event-a common occurrence during spring and summer in Oklahoma. The SGP site also acquired the equipment necessary to calibrate multifilter rotating shadowband radiometers and other similar sensors. Because each instrument 
has seven detectors that require calibration and characterization at all solar viewing angles (sunrise to sunset), a very precise calibration setup is required, as well as a significant amount of time to complete the procedure. Calibration procedures were formalized, staff training was completed, and calibration activities are underway. This enhancement adds a significant and important capability to the ACRF.

\section{Atqasuk Joins International Network of Meterological Stations}

The NSA site in Atqasuk is proving useful to climate modelers because this inland site is more homogenous and uniform than coastal sites, such as Barrow, during summer months. Enhancements to the instrument suite in Atqasuk last year led to a recent addition that solidified Atqasuk's position on the international science map as a key site for atmospheric measurements. On July 15, 2007, Atqasuk instruments began providing meteorological data to SuomiNet, an international network of global positioning system (GPS) receivers. These receivers are configured and managed to generate near-real-time estimates of precipitable water vapor in the atmosphere, total electron content in the ionosphere, and other meteorological and geographical information.

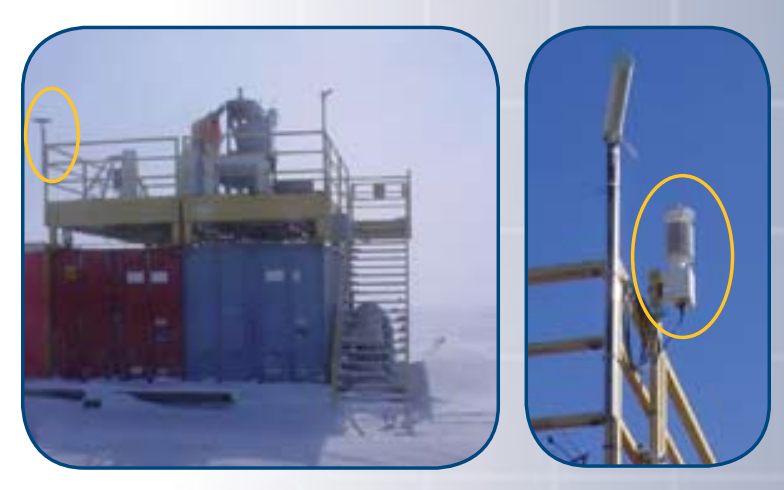

The relatively minor addition of a "met pack" - for measuring barometric pressure, temperature, and relative humidity - to the existing GPS receiver qualified the Atqasuk site for inclusion in the SuomiNet community. The same model of met pack is also deployed at 15 extended facilities at the SGP site that are part of the SuomiNet. Estimates of precipitable water vapor at 30-minute intervals are now available from the ARM Archive. The low-cost addition of the Atqasuk site to SuomiNet provides an additional meteorological datastream for use by the science community.

\section{Data on Display}

The ACRF developed and deployed a new wireless data display for the grand opening of the new Barrow Arctic Research Center in Alaska. More than 300 people gathered for the June event, which culminated years of planning and construction on the $\$ 19.9$ million, 20,000 square-foot science center, sponsored by NSF and NOAA. Senator Ted Stevens (R-Alaska) joined Max Ahgeak of the Ukpeagvik Iñupiat Corporation and many other regional dignitaries to kick off the event.

As the ribbon was cut, ACRF operations staff released a ceremonial weather balloon to transmit data to the nearby ACRF instrument shelter. ACRF also provided public information materials along with the new data display. Once communications and information-technology infrastructure are completed in the new center, a permanent ACRF data display will be located there for visitors and researchers. Plans are underway to package and deploy a similar display for each ACRF site data system.

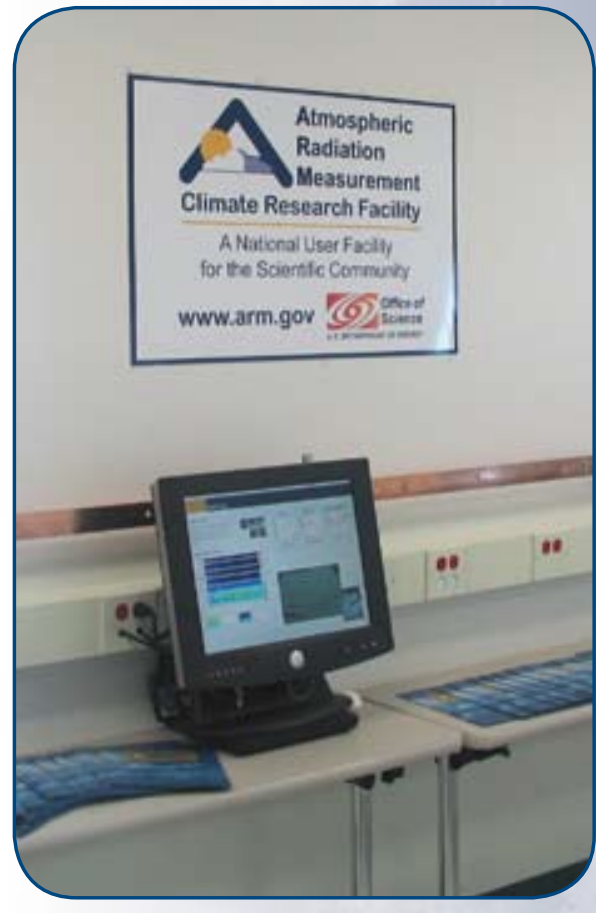

The new ACRF wireless data display is surrounded by information materials at the opening ceremony. The wireless antenna is hidden above the ceiling tiles. 


\section{Instrument Enhancements}

\section{Multifilter Radiometer Added to Cessna}

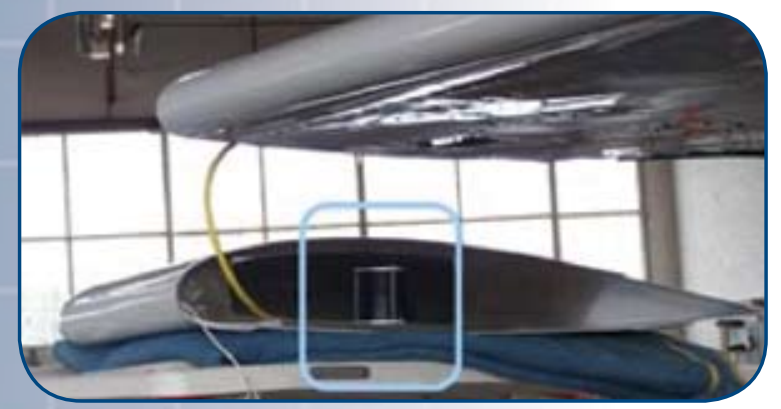

Downward-facing multifilter radiometers (MFRs) are instruments used to measure the intensity and distribution of reflected energy from different surfaces, such as grass or dirt. The relative amount of reflected energy_also called "surface spectral albedo"-is important for determining the amount of energy exchanged between the surface and atmosphere in a given location. In May, an MFR was added to the instrument payload on the Cessna 206, which acquires routine in-situ aerosol profiles and carbon measurements at the SGP site.

A multifilter radiometer is positioned inside the Cessna's new starboard wingtip extension.

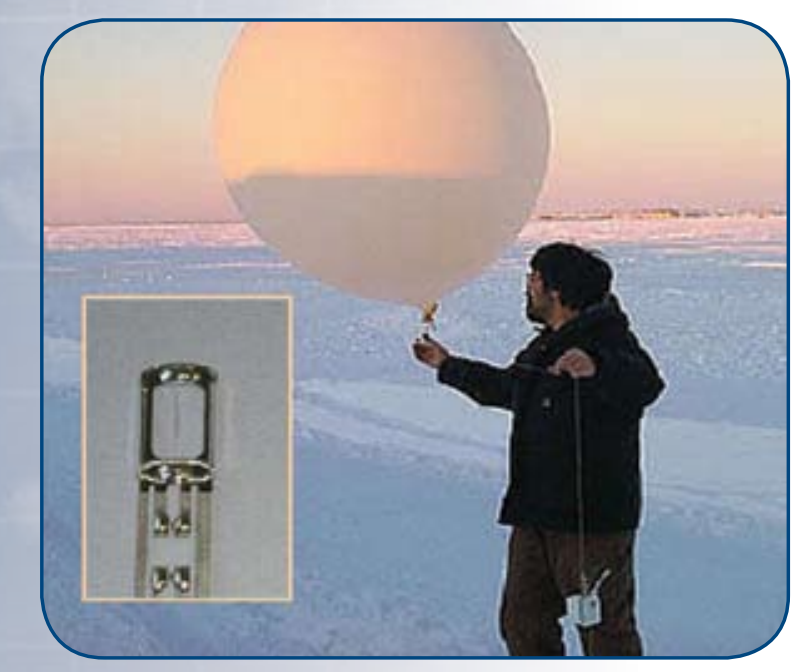

Attached to weather balloons by a string, the radiosonde package contains a variety of sensors for obtaining atmospheric data. The temperature sensor (inset) is situated at a 45-degree angle in this photo.
Historically, surface spectral albedo measurements at the SGP site were only possible using downward facing MFRs positioned at the 25-meter level of the 60-meter tower in a wheat field at the SGP Central Facility, and on a 10-meter tower in the adjoining pasture. This limited spatial coverage resulted in a very narrow data set. The addition of an MFR to the Cessna payload allows routine measurements of surface spectral albedo over a much broader area around the SGP Central Facility.

\section{Radiosonde Sensor Strengthened}

Small sensor packages called radiosondes (or "sondes") are used to transmit atmospheric information from weather balloons as they rise through the air. In 2007, the supplier of sondes used at all the ACRF sites introduced an improved temperature sensor that replaced the sensor's protective boom frame. The new reinforced framework of strong quartz fiber material is integrated into the sensor's structure, offering a number of benefits:

- five times better mechanical strength without losing responsiveness and accuracy

- very small solar radiation absorption

- less prone to damage during flight preparation and ascension

- improved air flow to the sensor due to removal of the boom frame.

Though the use of quartz fiber increases the thermal mass of the sensor, removal of the old boom structure improves heat transfer from the ambient air. This results in a net decrease of thermal mass on the sensor to maintain the needed response time. It also compensates for the slightly increased radiation absorption, so no correction technique is needed. Because of the reinforced structure, the new sensor is especially useful if sondes are tethered together and launched simultaneously.

\section{New High-Frequency Microwave Radiometer Provides Improved Sensitivity}

A microwave radiometer (MWR) is essentially a sensitive microwave receiver that is tuned to measure the microwave emissions of vapor and liquid water molecules in 
the atmosphere at specific frequencies. All of the ACRF sites include a 2-channel MWR operating at 23.8 and $31.4 \mathrm{GHz}$ as part of their measurement suite. In FY 2007, a new high-frequency MWR was deployed at the SGP Central Facility. A representative from the instrument manufacturer in Germany traveled to the SGP site to direct the installation of the new radiometer, carry out its initial calibration, and provide training on its operation and maintenance to the instrument mentor and local operations staff.

Operating at frequencies of 90 and $150 \mathrm{GHz}$, measurements from the new radiometer are more sensitive to the presence of liquid water than the currently deployed MWRs. By combining measurements from both instruments, more accurate estimates of the amount of liquid water (i.e., the liquid water path, or LWP) in thin clouds can be obtained than can be achieved using the 2-channel MWR alone. Accurate measurements of LWP are necessary to accurately model the contributions of thin clouds to radiative feedback processes. After completing acceptance testing and evaluation at the SGP site, the new radiometer will be deployed at the NSA site in Barrow, where thin clouds are prevalent. A second unit was shipped to Germany and deployed with the ARM Mobile Facility (see Featured Field Campaigns).

\section{Data Delivery}

\section{External Data Center Recognized for Contributions, Service to Science Community}

In celebration of its tenth year of operation, the ARM External Data Center, which is managed by Brookhaven National Laboratory, was recognized for its outstanding contribution to the scientific user community.

The External Data Center collects and processes a wide variety of data — including model, satellite, and surface data — from other climate monitoring and research programs to supplement the data collected at the ACRF sites. The combination of these data is more valuable than either data set alone.

The ACRF provides these data from external sources because they are usually not easily accessible from the original source. More information about the External Data Center and documentation for all the external data sets is available at www.xdc.arm.gov.

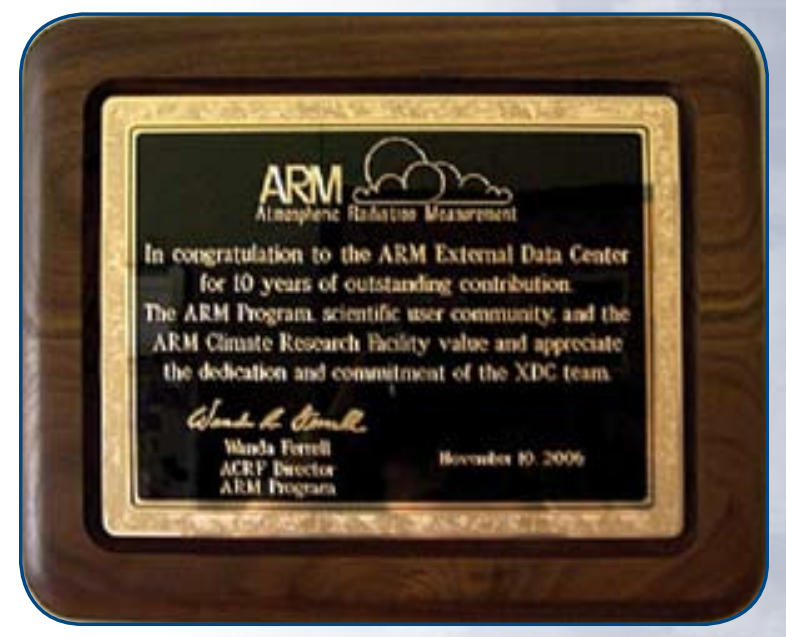

Dr. Wanda Ferrell, ACRF Program Director, presented XDC manager Richard Wagener with a plaque of recognition and thanks on November 10, 2006.

Working with partners from NOAA, the ARM External Data Center acquired long-term observations of surface air temperature and hourly total precipitation from the U.S. Climate Reference Network (USCRN), a network of climate change monitoring stations developed by NOAA. Previously inaccessible to users outside the NOAA user group, data back to 2002 from the Barrow and Stillwater stations are now available to the climate research community through the External Data 
Center. In a separate Arctic research effort, researchers analyzed more than 30 years of surface irradiance data from Barrow, Alaska, resulting in high temporal resolution data (1- to 3-minute averages) and quality-assured hourly averages that are now available at the ARM Archive.

Also at the ARM Archive, data and documentation from the first Intercomparison of Radiation Codes in Climate Models are now available. This 1980s climate modeling project eventually led to the creation of the ARM Program. Archived project information includes all available correspondence, publications, reports, workshops and meetings, model test cases, solar and infrared tabular results, a set of singlemodel results, and infrared line-by-line results.

\section{Datastream Database Speeds Flow of Information}

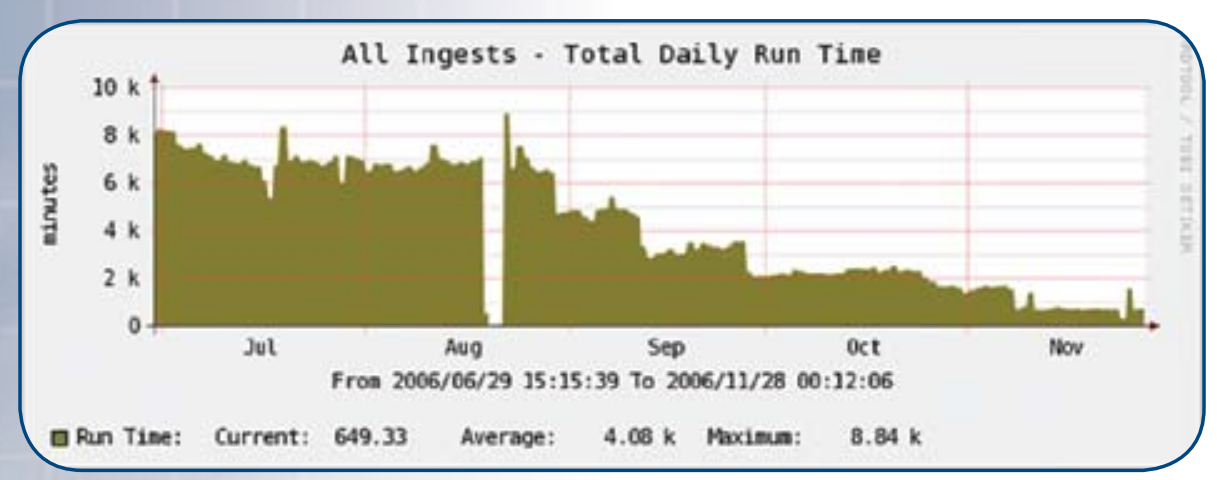

Replacement of the old technical database with the new Data System Database yielded dramatic results_-particularly in improved ingest run times-and provides maximum processing capacity for data system growth.
Scientific instrumentation at the ACRF sites generates massive amounts of raw data for atmospheric research, which are processed at the ACRF Data Management Facility housed at the Pacific Northwest National Laboratory. In late 2006, the Data Management Facility completed a 2-year process of incremental upgrades and migration of metadata to replace its old "technical" database processing capabilities with a new Data System Database. The new database engine was chosen because of its maturity and full-featured database capabilities, as well as its open-source licensing features, which simplify data distribution to the various remote ACRF sites.

Since nearly the outset of the ARM Program more than 15 years ago, the Data Management Facility relied on an internal "technical database" to store the datastream definitions (field names and attributes) and configurations used in processing ARM data. While functional, the technical database had room for improvement in performance, security, and especially in capability. To retire that database, every datastream ingest needed to be re-released and tested with the new database. After installing a copy of the new database at the data reprocessing center at Oak Ridge National Laboratory, the ARM Archive reported a 120-fold increase in performance on long-running jobs.

\section{Communication, Education and Outreach}

\section{Teachers Sponsored to Attend Education Conference Focused on Polar Climate}

One of the goals of the ACRF Education and Outreach Program is to promote awareness and understanding of climate studies in each of the ACRF host communities. This goal is especially important during the International Polar Year (IPY) from March 2007 to March 2009, when the Arctic region is a focal point for international scientific research. As part of its IPY outreach efforts, the ACRF 
Education and Outreach Program sponsored two teachers from Barrow, Alaska-one of the ACRF's host communities - to attend the annual conference of the National Science Teacher's Association (NSTA) in St. Louis, Missouri. The teachers were selected by the North Slope Borough School District to attend the conference, which took place in March. This year's conference featured several symposia and workshops on climate studies at the poles. After attending the conference, the teachers said they plan to teach about IPY during the next school year.

The ACRF Education and Outreach also contributed footage from the educational kiosk developed for Barrow to help build the traditional knowledge perspectives in the various multimedia resources associated with POLAR-PALOOZA. This IPY collaboration, sponsored by NASA and NOAA, features a national tour and video broadcasts. Lesson plans and classroom activities developed by the Education and Outreach Program will also be adapted for use during POLAR-PALOOZA K-12 workshops. Footage from the Barrow kiosk was also provided to WGBH Boston, public television's preeminent production house, for its Learning from the People series. This special collection is available on the Teachers' Domain Digital Library for access by educators around the world.

\section{Climate Education Kiosks Unveiled on Nauru and Manus Islands}

Surrounded by the Pacific Ocean, inhabitants of Nauru and Manus islands have a keen understanding of the importance of weather and climate. Pacific Islanders face coastal erosion, drought, and rising sea level as possible impacts of climate change. Such concerns related to climate change have cultivated a growing need for science education and public awareness of climate research. In November 2006 and June 2007, ACRF Education and Outreach installed interactive kiosks on Nauru and Manus Island, respectively. The kiosks enable users to select and listen to interviews about climate change and climate research taking place in their communities. The Nauru kiosk is located in the departure lounge of the local airport, while the Manus kiosk is located at a local supermarket in the village of Lorengau.

The TWP kiosks are part of a series called Climate Change: Science and Traditional Knowledge. Featured interviews with scientists from the ARM Program and Australian Bureau of Meteorology give users an introduction to atmospheric science and the basic concepts essential to understanding climate change. Several animations of the greenhouse effect and enhanced greenhouse effect complement the interviews. The kiosks also feature interviews with community elders discussing their observations of climate change. Designed to be played on classroom or personal computers, the kiosk program is distributed on disc to teachers and students from ACRF host communities.

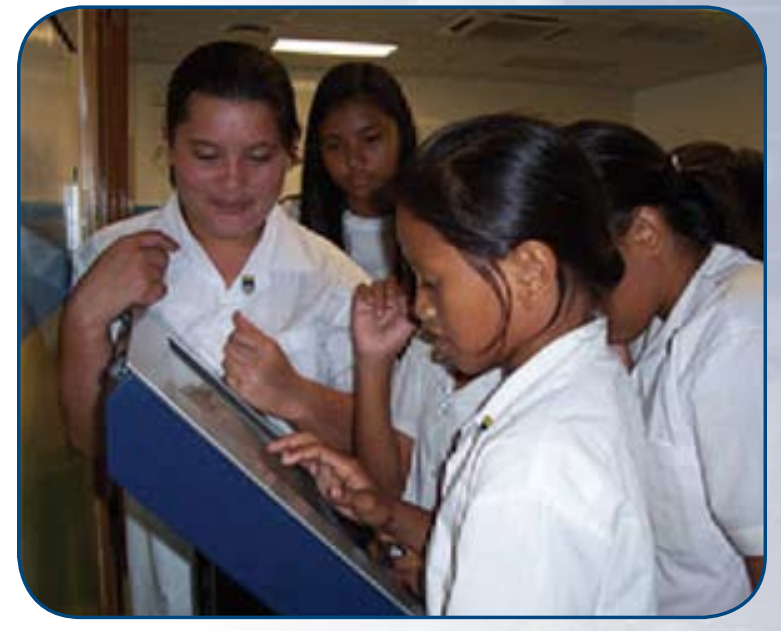

Nauruan students crowd around the new touch-screen kiosk to learn more about climate change. 


\section{Media Event Spurs Local, Regional Interest}

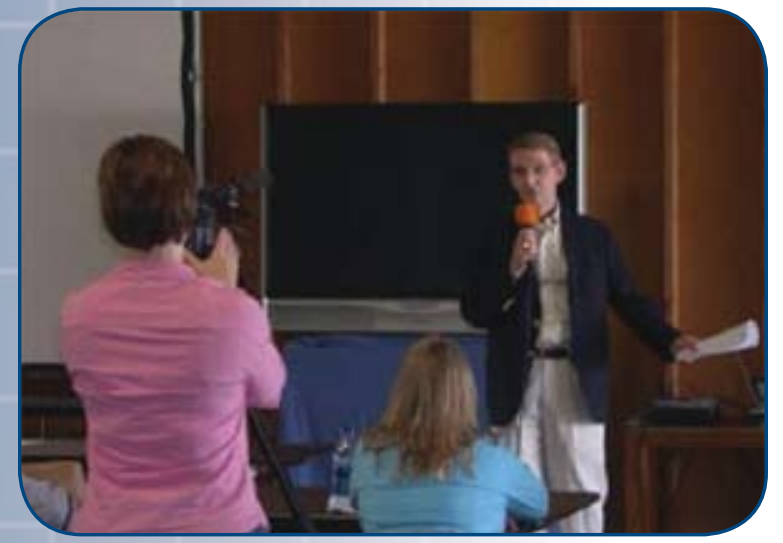

Dr. Jerry Elwood, Director of DOE's Climate Change Research Division, describes how the field campaigns in Oklahoma are contributing to the DOE's climate research efforts.

Media and distinguished guests were invited to a media day in Ponca City, Oklahoma, to learn about the CLASIC and CHAPS field campaigns taking place in the region. In addition to the media, former Oklahoma State Senator Paul Muegge and current State Senator David Myers attended, as did Dr. Ken Crawford, the state climatologist for Oklahoma and "father of the Oklahoma Mesonet." The event began with an introduction from special guest Dr. Jerry Elwood, Director of DOE's Climate Change Research Division. His opening discussion was followed by science overviews from the principal investigators for both field campaigns.

The event's morning activities were held at the Ponca City Airport, headquarters for mission planning and the primary field base for six of the nine participating aircraft during the campaigns. In the afternoon, attendees were invited to visit the SGP Central Facility, about 45 minutes from Ponca City. They were treated to a guided tour of the various instruments and operations activities around the SGP Central Facility, one of the primary surface sites for the "land" portion of CLASIC. Several local and regional news stories resulted from the event, including a television program produced for the Oklahoma Educational Television Authority, Oklahoma’s public education news channel.

\section{Modernized ACRF Exhibit Draws Conference Attendees}

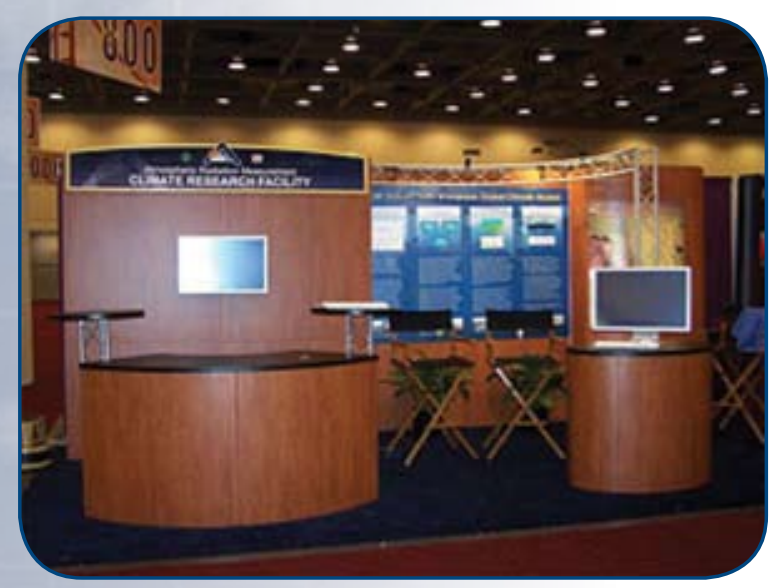

At the 2006 American Geophysical Union Fall Meeting in December, ACRF staff noticed an increase in traffic to its new exhibit. With over 1120 sessions and 13,023 abstracts to choose from (an increase of more than 15 percent over the 2005 Fall Meeting), nearly 14,000 scientists from around the world crowded the halls of the Moscone Center in San Francisco to share their research on Earth and space sciences. Former Vice President Al Gore also made an appearance on December 14, holding a Town Hall Meeting on "Climate Change: The Role of Science and the Media in Policymaking."

Meeting attendees were drawn to the new, modern exhibit, where ACRF staff fielded questions regarding ARM data availability and accessibility. ACRF staff also shared the ACRF mission and goals with

Debuting at the 2006 Fall Meeting of the American Geophysical Union, the new ACRF display includes a more modern structure and enhanced visual aids. interested participants and provided information regarding the ARM science program and the newly formed ARM Aerial Vehicles Program. And once again, the ACRF Education and Outreach climate change coloring and activity book was a popular item for visiting teachers and students. 



\section{风 2007 Field Campaigns}

\begin{tabular}{|c|c|c|c|}
\hline Dates & Name & Status & Description \\
\hline \multicolumn{4}{|r|}{ North Slope of Alaska } \\
\hline $\begin{array}{l}\text { August } 2006- \\
\text { July } 2007\end{array}$ & $\begin{array}{l}\text { Pyranometer Infrared (IR) } \\
\text { Loss Study }\end{array}$ & Completed & $\begin{array}{l}\text { This field campaign will provide a long-term (1-year) set of measurements needed to investigate } \\
\text { and refine the IR loss correction methodology for data obtained at the NSA sites. An extensive } \\
\text { effort will be directed toward gaining an understanding of what effects the current ventilator } \\
\text { heaters might be having on the basic measurements. The campaign will also investigate the } \\
\text { various permutations of the amount of ventilation and heating in an effort to optimize the } \\
\text { broadband measurement strategy for the NSA sites. Overall, the campaign is targeted at improv- } \\
\text { ing the understanding, quality, and accuracy of radiometer measurements at the NSA. }\end{array}$ \\
\hline $\begin{array}{l}\text { February } 2007- \\
\text { March } 2007\end{array}$ & $\begin{array}{l}\text { Radiative Heating in } \\
\text { Underexplored Bands } \\
\text { Campaign (RHUBC) }\end{array}$ & Completed & $\begin{array}{l}\text { The RHUBC campaign was conducted at the NSA site in Barrow, Alaska, to obtain detailed } \\
\text { observation of the downwelling IR radiation in the rotational and } \mu 2 \text { water vapor bands. } \\
\text { High-spectral-resolution observations were collected by Fourier Transform Spectrometers (FTS), } \\
\text { including the ARM AERI-ER and TAFTS. The primary goals of the campaign included clear- } \\
\text { sky radiative closure studies, instrument cross-calibration and validation, and the investigation } \\
\text { of the radiative properties of the sub-Arctic cirrus. For more information, see the Featured Field } \\
\text { Campaigns section of this report. }\end{array}$ \\
\hline $\begin{array}{l}\text { February } 2007- \\
\text { July } 2007\end{array}$ & $\begin{array}{l}\text { RHUBC Extended } \\
\text { Operations }\end{array}$ & Completed & $\begin{array}{l}\text { This field campaign provided cross-calibration and validation of the TAFTS and AERI-ER } \\
\text { instruments used during RHUBC. A primary objective was to conduct clear-sky water vapor } \\
\text { spectroscopy studies that reduced the uncertainties regarding foreign-broadened water vapor } \\
\text { continuum and unpredictability in the water vapor absorption line parameters. To address these } \\
\text { concerns, ground-based scanning radiometers (GSR) that began operating during RHUBC } \\
\text { continued through July } 2007 \text {. The GSR allowed for the collection of radiometric observations at } \\
\text { frequencies ranging from } 50 \text { to } 400 \mathrm{GHz} \text {. The data set will prove valuable in further investiga- } \\
\text { tions regarding model studies, calibration issues, and the observance of stratospheric water vapor } \\
\text { from a ground-based platform. }\end{array}$ \\
\hline $\begin{array}{l}\text { June } 2006- \\
\text { Ongoing }\end{array}$ & $\begin{array}{l}\text { National Science Founda- } \\
\text { tion (NSF) Ultraviolet (UV) } \\
\text { Monitoring Support }\end{array}$ & In Progress & $\begin{array}{l}\text { In this ongoing field campaign, ACRF is providing onsite support to the NSF UV monitor- } \\
\text { ing network, which measures solar UV radiation at six high-latitude sites and at San Diego, } \\
\text { California. This network was founded in } 1987 \text { in response to severe ozone depletion reported } \\
\text { in Antarctica and is operated by Biospherical Instruments, Inc. Instrumentation installed at } \\
\text { network sites includes high-resolution, UV-visible spectroradiometers (measuring spectral irradi- } \\
\text { ance between } 280 \text { and } 600 \text { nanometer) as well as multi-channel filter radiometers. The network } \\
\text { site at Barrow, Alaska, was established in 1991, with instrumentation located in the Ukpeagvik } \\
\text { Inupiat Corporation building. In } 2005 \text {, ACRF took over site operations support previously pro- } \\
\text { vided by NOAA's Climate Monitoring and Diagnostics Laboratory. Preliminary data from the } \\
\text { network are available within } 1 \text { week after collection and can be accessed via the project's website } \\
\text { at www.biospherical.com/NSF. The project's website also provides additional information on } \\
\text { the network, its data, and applications. }\end{array}$ \\
\hline $\begin{array}{l}\text { June } 2006- \\
\text { Ongoing }\end{array}$ & $\begin{array}{l}\text { Global Positioning System } \\
\text { (GPS) Base Station - Atqasuk }\end{array}$ & In Progress & $\begin{array}{l}\text { A GPS base station in Atqasuk provides a local source of geodetic quality differential correc- } \\
\text { tions for GPS data post-processing by scientists and others operating in the Atqasuk area of } \\
\text { the North Slope. With security, power, and ethernet communications provided at the Atqasuk } \\
\text { site, the station runs continuously, and } 15 \text {-second sample rate data are archived at UNAVCO } \\
\text { (facility.unavco.org) and available to the public. Higher sample rate data are also recorded on } \\
\text { the receiver in hourly files and will be made available to users as needed. Because all data are } \\
\text { available via the Internet, users do not need to have physical access to the receiver. }\end{array}$ \\
\hline $\begin{array}{l}\text { July } 2007- \\
\text { October } 2007\end{array}$ & $\begin{array}{l}\text { Atmospheric Infrared } \\
\text { Sounder (AIRS) Validation } \\
\text { Soundings - Phases IV and } \\
\text { VII (Also at SGP and TWP) }\end{array}$ & Completed & $\begin{array}{l}\text { The ACRF conducted a special series of radiosonde launches in support of validation studies for } \\
\text { the AIRS instrument aboard NASA's Aqua satellite. The instrument is intended to make highly } \\
\text { accurate measurements of air temperature, humidity, clouds, and surface temperature. The data } \\
\text { collected will be used by scientists worldwide to better understand the weather and climate. }\end{array}$ \\
\hline $\begin{array}{l}\text { August } 2007- \\
\text { June } 2008\end{array}$ & $\begin{array}{l}\text { Evaluation of Heated Ventila- } \\
\text { tors in the Arctic }\end{array}$ & In Progress & $\begin{array}{l}\text { The harsh conditions at the NSA required that electric heaters be installed inside the ventilators } \\
\text { of the broadband radiometers to prevent hoarfrost and snow from affecting the measurements } \\
\text { being obtained. This campaign will evaluate potential effects the ventilator heaters may be hav- } \\
\text { ing on the basic measurements to improve the understanding, the quality, and the accuracy of } \\
\text { the radiometer measurements at the NSA. This campaign builds on the results of the "Pyrano- } \\
\text { meter IR Loss Study" (see above). }\end{array}$ \\
\hline
\end{tabular}




\begin{tabular}{|c|c|c|c|}
\hline \multicolumn{4}{|r|}{ Southern Great Plains } \\
\hline $\begin{array}{l}\text { March } 2000- \\
\text { October } 2007\end{array}$ & In Situ Aerosol Profiles (IAP) & In Progress & $\begin{array}{l}\text { In March 2000, a Cessna } 172 \text { was outfitted with a subset of the instrument package at the SGP } \\
\text { surface site to obtain vertical profiles of aerosol optical properties over the surface site 2-3 times } \\
\text { per week. The success of the program in its first few years resulted in an upgrade to a slightly } \\
\text { larger Cessna in } 2006 \text {. As of April } 2006 \text {, the IAP aerosol package measures light scattering, back } \\
\text { scattering and absorption at } 3 \text { wavelengths for particles with diameters less than approximately } \\
5 \text { microns. It also measures submicron light scattering at } 1 \text { wavelength for } 3 \text { humidities to pro- } \\
\text { vide an indication of the hygroscopic nature of the aerosol. Non-aerosol instruments which have } \\
\text { been incorporated into the aerosol package include a programmable flask package for obtaining } \\
\text { samples of carbon dioxide and other trace gases at each flight level and continuous gas analyzers } \\
\text { for carbon dioxide and ozone. }\end{array}$ \\
\hline $\begin{array}{l}\text { March } 2006 \text { - } \\
\text { June } 2011\end{array}$ & Magnetic Field Observations & In Progress & $\begin{array}{l}\text { Collaborators from the University of California installed a magnetometer at the SGP boundary } \\
\text { facility at Purcell, Oklahoma, and for the next } 5 \text { years will collect continuous measurements of } \\
\text { the magnetic field. These data can be used to study a wide range of physical processes of the sun- } \\
\text { Earth system, including magnetic storms, ionospheric currents, and other phenomena whose } \\
\text { source energy originates from enhanced solar activity. }\end{array}$ \\
\hline $\begin{array}{l}\text { May } 2006 \text { - } \\
\text { July } 2007\end{array}$ & $\begin{array}{l}\text { Combined Wind Profiler and } \\
\text { Polarimetric Radar Study of } \\
\text { Precipitation }\end{array}$ & Completed & $\begin{array}{l}\text { In this campaign, a 915-MHz boundary-layer radar (BLR) at the SGP boundary facility at } \\
\text { Purcell, Oklahoma, is being used to study the vertical structure of rain under various meteo- } \\
\text { rological conditions. Unlike many remote sensing instruments, a vertically pointing BLR can } \\
\text { directly measure the size distribution of rainfall particles. Precipitation data obtained using the } \\
915-\mathrm{MHz} \text { BLR will be compared against measurements made using a ground-based disdrometer } \\
\text { and from the National Severe Storms Laboratory polarimetric WSR-88D radar. In addition, } \\
\text { data from the NOAA Profiler Network 404-MHz radar will be used in the study. }\end{array}$ \\
\hline $\begin{array}{l}\text { May } 2006- \\
\text { October } 2009\end{array}$ & HydroKansas & In Progress & $\begin{array}{l}\text { For } 3.5 \text { years, the Whitewater River (Kansas) watershed will serve as the focus of a NSF long- } \\
\text { term study intended to develop and field-test new innovative theoretical approaches for better } \\
\text { understanding the non-linear coupling among atmospheric processes, the landscape, vegetation } \\
\text { and important elements of the hydrological cycle, especially as they relate to changes in climate } \\
\text { and in the occurrence of extreme events such as floods. }\end{array}$ \\
\hline $\begin{array}{l}\text { June } 2006- \\
\text { August } 2009\end{array}$ & $\begin{array}{l}\text { Observation-Based Precipita- } \\
\text { tion Microphysics Study }\end{array}$ & In Progress & $\begin{array}{l}\text { Understanding precipitation microphysics is important in accurate quantitative precipitation } \\
\text { estimation and forecast. A } 2 \mathrm{D} \text { video disdrometer (2DVD) measures size, shape, orientation and } \\
\text { falling speed of each precipitating particle. A polarimetric radar provides information about } \\
\text { cloud/precipitation physics with a large spatial coverage. The University of Oklahoma purchased } \\
\text { and deployed a 2DVD at the SGP Purcell boundary facility to measure hydrometeor DSD. A } \\
\text { 2DVD from the National Center for Atmospheric Research was placed side-by-side with the } \\
\text { university's 2DVD, providing data to improve the understanding of precipitation microphysics } \\
\text { for the Great Plains region of the United States, to develop radar-retrieval algorithms/forward } \\
\text { operators, and to verify polarimetric radar measurements. }\end{array}$ \\
\hline $\begin{array}{l}\text { July } 2006 \text { - } \\
\text { December } 2008\end{array}$ & Aircraft Carbon & In Progress & $\begin{array}{l}\text { Priorities for this campaign are to acquire the ability to measure carbon dioxide concentrations } \\
\text { and sample for a suite of trace gases from the surface to mid-troposphere. Airborne measure- } \\
\text { ments of trace gases will (a) provide valuable data for addressing carbon-cycle questions that } \\
\text { have been identified by the U.S. Climate Change Research Program and the North American } \\
\text { Carbon Program, (b) facilitate the calibration of the NASA Orbiting Carbon Observatory, and } \\
\text { (c) provide a basis from which to develop inverse methods to infer ecosystem carbon exchange } \\
\text { and quantify anthropogenic combustion emissions. }\end{array}$ \\
\hline $\begin{array}{l}\text { October } 2006- \\
\text { November } 2006\end{array}$ & $\begin{array}{l}\text { Microwave Radiometer } \\
\text { (MWR) Intercomparison } \\
\text { Study }\end{array}$ & Completed & $\begin{array}{l}\text { The principal objective of this field campaign was to address the repeatability of ACRF MWR } \\
\text { brightness temperature measurements. Also important to the study were comparisons of precipi- } \\
\text { table water vapor derived from MWR brightness temperature measurements with precipitable } \\
\text { water vapor derived from radiosondes and SuomiNet global positioning systems. This will allow } \\
\text { scientists to indirectly assess the current accuracy of the MWR brightness temperature and } \\
\text { retrievals. Six MWRs located at the SGP Central Facility collected concurrent data that will be } \\
\text { used to determine hardware and software issues that may affect the retrieved values for precipi- } \\
\text { table water vapor and liquid water path. }\end{array}$ \\
\hline October 2006 & $\begin{array}{l}\text { Evaluation of Unattended } \\
\text { EZ_Lidar Performances }\end{array}$ & Completed & $\begin{array}{l}\text { Scientists routinely use light detection and ranging (lidar) systems to obtain data about cloud } \\
\text { and aerosol layering and optical properties. In October 2006, the SGP site's Micropulse Lidar } \\
\text { (MPL) and a new EZ Lidar (from LEOSPHERE) were used to obtain measurements of aerosols } \\
\text { and cloud structure at the SGP Central Facility. Evaluation of the EZ Lidar performance by } \\
\text { direct comparison with coincident MPL data will allow scientists to validate the EZ Lidar as a } \\
\text { new tool for automated retrievals of aerosol and cloud measurements. }\end{array}$ \\
\hline
\end{tabular}




\begin{tabular}{|c|c|c|c|}
\hline $\begin{array}{l}\text { October } 2006- \\
\text { April } 2008\end{array}$ & Aura Satellite Validation & In Progress & $\begin{array}{l}\text { Solar Radiance Transmission Interferometer is an FTS system, including an automatic solar } \\
\text { tracker and a computer for control, data processing, and storage. This system generates very } \\
\text { high-spectral-resolution IR spectra of the Earth's atmosphere using the sun as the external } \\
\text { source. Spectral data will be collected during routine overpasses of the SGP site by NASA's Aura } \\
\text { satellite, and weather permitting, other times of the day. The spectra will be analyzed for column } \\
\text { amounts and vertical distributions of gases measured by the satellite. }\end{array}$ \\
\hline $\begin{array}{l}\text { November } 2006 \text { - } \\
\text { March } 2008\end{array}$ & $\begin{array}{l}\text { Radon Measurements } \\
\text { of Atmospheric Mixing } \\
\text { (RAMIX) }\end{array}$ & In Progress & $\begin{array}{l}\text { Radon is an effective tracer of atmospheric mixing because it is emitted relatively universally } \\
\text { from the land surface with a short half-life, allowing for characterization of the mixing processes } \\
\text { based on vertical profile measurements. In collaboration with NOAA's Climate Monitoring and } \\
\text { Diagnostics Laboratory, this field campaign will use atmospheric } 222 \mathrm{Rn} \text { (Radon) concentra- } \\
\text { tions obtained from measurements at the SGP } 60 \text {-meter tower to estimate the time-averaged } \\
\text { atmospheric mixing between various atmospheric layers and during selected convective events. } \\
\text { Mixing rates will also be measured rates to estimate regional carbon dioxide exchange. }\end{array}$ \\
\hline $\begin{array}{l}\text { November } 2006 \text { - } \\
\text { December } 2006\end{array}$ & $\begin{array}{l}\text { RS92 Radiosonde Relative } \\
\text { Humidity (RH) Sensor } \\
\text { Contamination Evaluation } \\
\text { Study }\end{array}$ & Completed & $\begin{array}{l}\text { To investigate potential biases in the humidity measurements obtained from radiosondes } \\
\text { launched from the SGP Central Facility, site operators conducted two ground checks on every } \\
\text { radiosonde launched for } 1 \text { month. The first check was done before the radiosonde was recon- } \\
\text { ditioned in the ground check set. Upon completion of the first ground check, the stabilized } \\
\text { values of the radiosonde in the ground check set were logged, and the procedure restarted. The } \\
\text { difference in the readings before and after reconditioning indicated the amount of contamina- } \\
\text { tion removed during the reconditioning step. }\end{array}$ \\
\hline $\begin{array}{l}\text { March } 2006- \\
\text { March 2007; } \\
\text { April } 2007- \\
\text { December } 2007\end{array}$ & $\begin{array}{l}\text { Precision Gas Sampling } \\
\text { (PGS) Validation }\end{array}$ & $\begin{array}{l}\text { Completed; In } \\
\text { progress }\end{array}$ & $\begin{array}{l}\text { The purpose of this field campaign is to measure the surface fluxes and vegetation characteristics } \\
\text { in three fields near the SGP Central Facility. With field locations forming a roughly 10-kilo- } \\
\text { meter equilateral triangle, the flux measurements will be compared to Duke University Flux } \\
\text { Helicopter over-flights during the CLASIC field campaign. These and other carbon-cycle studies } \\
\text { will be valuable to the North American Carbon Program's Mid-Continent Intensive. }\end{array}$ \\
\hline $\begin{array}{l}\text { April } 2007- \\
\text { May } 2007\end{array}$ & $\begin{array}{l}\text { Infrared Atmospheric Sound- } \\
\text { ing Interferometer (IASI) } \\
\text { (MetOp-A)/ Atmospheric IR } \\
\text { Sounder (AQUA) Validation } \\
\text { Radiosonde Launch Support }\end{array}$ & Completed & $\begin{array}{l}\text { The IASI is the first of the advanced ultra-spectral resolution temperature, humidity, and } \\
\text { trace-gas-sounding instruments to be flown on the U.S. Joint Polar System of the National } \\
\text { Polar-Orbiting Operational Environmental Satellite System and the European MetOp opera- } \\
\text { tional satellites for improved weather, climate, and air-quality observation and forecasting. } \\
\text { Sponsored by NASA, radiosondes launched from all the ACRF sites support this international } \\
\text { airborne calibration/validation campaign focused on validating radiance observations and } \\
\text { meteorological products from the IASI. }\end{array}$ \\
\hline $\begin{array}{l}\text { April } 2007- \\
\text { May } 2007\end{array}$ & Howard Beltsville MWR & Completed & $\begin{array}{l}\text { The } 2006 \text { Water Vapor Validation Experiments at the Howard University Beltsville Research site } \\
\text { revealed unacceptable biases during intercomparisons of precipitable water vapor obtained from } \\
\text { a Radiometrics 2-channel MWR and SoumiNet GPS, which exceeded comparisons between } \\
\text { measurements from similar sensors at the SGP site during the AIRS Water Vapor Experiment } \\
\text { in 2003. Because these data are used for satellite validation, instrument intercomparisons, and } \\
\text { process studies, the highest-quality data must be obtained. The intercomparison of MWRs } \\
\text { operated at the SGP site was proposed to evaluate the reasons for the discrepancy. Results will } \\
\text { be incorporated into an ARM-developed operational and data-processing standards program at } \\
\text { Howard Beltsville. }\end{array}$ \\
\hline June 2007 & $\begin{array}{l}\text { Cloud LAnd Surface Interac- } \\
\text { tion Campaign (CLASIC) }\end{array}$ & Completed & $\begin{array}{l}\text { The CLASIC field campaign at the SGP site was conducted to advance the understanding of } \\
\text { cumulus convection and its controls. The science objectives specifically addressed the relation- } \\
\text { ship between land-surface processes and the observed cloud cover as well as the known model } \\
\text { deficiencies and gaps in the physical understanding of cloud and land-surface feedbacks. The } \\
\text { results of the campaign were intended to assist in the realization of the potential of ARM's new } \\
\text { instrument capabilities, to provide significant validation data for NASA's new active satellite } \\
\text { remote sensors, and to enhance ACRF capabilities by expanding into cross-discipline research. } \\
\text { For more information, see the Featured Field Campaigns section of this report. }\end{array}$ \\
\hline June 2007 & CLASIC Land Surface & Completed & $\begin{array}{l}\text { The CLASIC Land Surface campaign allowed for the determination of the level of up-scaling/ } \\
\text { aggregation required to understand the impact of landscape changes that affect energy balance/ } \\
\text { flux partitioning and impact on cloud and atmospheric dynamics. Critical factors for predicting } \\
\text { the sensible and latent heat fluxes at an acceptable accuracy for subsequent predictions of the } \\
\text { onset of cloud formation were defined. Measured hyper-spectral and broadband spectral indices } \\
\text { were used to establish the necessary parameters for accurate modeling of both energy and carbon } \\
\text { dioxide fluxes. }\end{array}$ \\
\hline June 2007 & CLASIC Radiosonde Support & Completed & $\begin{array}{l}\text { Supplemental radiosonde launches were provided during two 5-day campaigns in support of } \\
\text { CLASIC. This consisted of eight radiosonde launches per day at each of the SGP boundary } \\
\text { facilities, plus the routine 4-per-day launches at the Central Facility. }\end{array}$ \\
\hline June 2007 & Particle Phase Experiment & Completed & $\begin{array}{l}\text { Through the process of hypothesis, measurement and analysis, the objective of this field campaign } \\
\text { was to provide the cause-and-effect relationship between RH history and particle composition, } \\
\text { in addition to particle phase. An aerosol mass spectrometer was used to measure the chemical } \\
\text { composition and phase-change properties of particles ranging from } 40 \text { to } 400 \text { nanometers. }\end{array}$ \\
\hline
\end{tabular}




\begin{tabular}{|c|c|c|c|}
\hline June 2007 & $\begin{array}{l}\text { Land-Cloud Coupled Data } \\
\text { Assimilation System and } \\
\text { CLASIC }\end{array}$ & Completed & $\begin{array}{l}\text { In collaboration with the USDA Agricultural Research Service's Hydrology and Remote Sensing } \\
\text { Lab, this campaign focused on the validation and improvement of a land-cloud microphysics } \\
\text { coupled-data system designed by scientists from the University of Tokyo. The radiometer data } \\
\text { collected by the team, in combination with the extensive data obtained by CLASIC, were used } \\
\text { to provide improved methods for monitoring and assessment of land and atmospheric variables } \\
\text { that can alter climate, water resources, and agriculture. In turn, this would contribute to the } \\
\text { understanding of the interactive physical, chemical, and biological processes that regulate the } \\
\text { total Earth system. }\end{array}$ \\
\hline June 2007 & Prede Cimel Comparison & Completed & $\begin{array}{l}\text { The SGP site was the location for a direct comparison between the ACRF Cimel sunphotometer } \\
\text { and a commercial Prede tracking sun photometer. The Cimel sunphotometer forms the basis } \\
\text { of the NASA Aeronet network of sun photometers, while the Prede is widely used in Asia. The } \\
\text { Aeronet and Asian aerosol networks are playing increasingly important roles in characterizing } \\
\text { global aerosol distributions. This side-by-side comparison of these two instruments was the first } \\
\text { ever conducted. }\end{array}$ \\
\hline June 2007 & $\begin{array}{l}\text { 9.4-GHz Phase Array Radar } \\
\text { with CLASIC }\end{array}$ & Completed & $\begin{array}{l}\text { The phased-array radar used during the CLASIC field campaign reduced the cloud volume scan } \\
\text { time from minutes to seconds, thereby providing a unique mapping of precipitation. Compre- } \\
\text { hensive mapping of the 3D structure of shallow and deep precipitation was collected on a 50- } \\
\text { by } 50 \text {-kilometer domain around SGP site. This mapping can be used to evaluate the mesoscale } \\
\text { structure of cumulus convection, its organization, diurnal cycle and variability and is relevant } \\
\text { to land-surface processes and properties. Comparisons with the ACRF millimeter-wavelength } \\
\text { vertically pointing cloud radars and disdrometer will be used to calibrate the radar and develop a } \\
\text { relationship between reflectivity and rain rate. }\end{array}$ \\
\hline $\begin{array}{l}\text { June } 2007- \\
\text { July } 2007\end{array}$ & $\begin{array}{l}\text { Southern Great Plains Aerosol } \\
\text { Evolution Study (SGPAES) }\end{array}$ & Completed & $\begin{array}{l}\text { In collaboration with Texas A\&M University, the focus of SGPAES was to evaluate the trans- } \\
\text { formation of an aerosol species over time by condensation/sorption reactions given ambient } \\
\text { conditions in a rural location. The hypothesis was that the field campaign would assist in gain- } \\
\text { ing understanding of the effects of aerosol growth processes on size distribution, hygroscopic } \\
\text { growth, and aerosol extinction. The data collected were used to recover data characteristics and } \\
\text { were then parameterized using lognormal fits to retrieve the data statistics. }\end{array}$ \\
\hline June 2007 & $\begin{array}{l}\text { Sun and Aureole Measure- } \\
\text { ment (SAM) Support for } \\
\text { CLASIC }\end{array}$ & Completed & $\begin{array}{l}\text { The SAM ground instruments were deployed to support the CLASIC and CHAPS field } \\
\text { campaigns, specifically to overlap the aerosol optical depth measurements of the Cimel sun } \\
\text { photometers. These measurements extended the outside diameter range and provided precise } \\
\text { measurements of thin to moderately thick clouds. Measurements garnered from SAM provided } \\
\text { column-integrated values, complementing in situ point measurements of aircraft probes and } \\
\text { retrievals using lidars and radars. }\end{array}$ \\
\hline $\begin{array}{l}\text { July } 2007- \\
\text { June } 2008\end{array}$ & $\begin{array}{l}\text { Single-Frequency GPS Water } \\
\text { Vapor Network }\end{array}$ & In Progress & $\begin{array}{l}\text { In this ongoing field campaign, a network of GPS stations will provide observations collected to } \\
\text { detect changes in moisture associated with multiple atmospheric processes. The collected data } \\
\text { will be useful for studying water vapor structure, variability, temporal cycles, and evolution } \\
\text { during cloud formation and convective events. Because of the unique density of the GPS } \\
\text { stations, observations of atmospheric water vapor can be measured on horizontal scales as } \\
\text { small as } 1 \text { kilometer. }\end{array}$ \\
\hline $\begin{array}{l}\text { July } 2007- \\
\text { August } 2007\end{array}$ & $\begin{array}{l}\text { Prede Cimel Comparison } \\
\text { - Extended Observations }\end{array}$ & Completed & $\begin{array}{l}\text { In June 2007, the SGP site was the host location for a direct comparison between the ACRF } \\
\text { Cimel sunphotometer and a commercial Prede tracking sunphotometer. These instruments are } \\
\text { used in aerosol networks in the United States and Asia, respectively. Aerosols play a complex } \\
\text { role in climate on local and extended scales, impacting air quality and affecting the degree and } \\
\text { nature of cloud cover, as well as the quantity and frequency of precipitation and water resources. }\end{array}$ \\
\hline $\begin{array}{l}\text { August } 2007- \\
\text { September } 2007\end{array}$ & $\begin{array}{l}\text { IR Sky Imager (IRSI) Inter- } \\
\text { Comparison Study }\end{array}$ & Completed & $\begin{array}{l}\text { At the request of the ARM Radiative Processes Working Group, a Blue Sky Imaging Ltd. (BSI) } \\
\text { All-Sky Thermal IR Camera was purchased and deployed at the SGP Guest Instrument Facility } \\
\text { in October 2005. Based on analysis of the data collected, three additional IRSIs were proposed } \\
\text { for an intercomparison to evaluate measurements of cloud fraction and to compare the daytime } \\
\text { values with the SGP sites Total Sky Imager (TSI). }\end{array}$ \\
\hline September 2007 & Nocturnal Surface Flux IOP & Completed & $\begin{array}{l}\text { This campaign at the SGP Central Facility was focused on clarifying the characteristics of } \\
\text { nocturnal transport in very stable boundary layers. The lessons learned from this research will } \\
\text { characterize scalar and turbulent transport near the surface and its respective links to carbon } \\
\text { dioxide and other scalar fluxes near the surface. }\end{array}$ \\
\hline $\begin{array}{l}\text { September } 2007- \\
\text { September } 2007\end{array}$ & $\begin{array}{l}\text { Nocturnal Surface Flux - } \\
\text { Perfluorocarbon Tracer Study }\end{array}$ & Completed & $\begin{array}{l}\text { In collaboration with the Brookhaven National Laboratory, this field campaign at the SGP site } \\
\text { combined flux measurements from the } 10 \text {-meter tower with atmospheric boundary-layer instru- } \\
\text { ments to improve understanding of the processes affecting atmospheric carbon dioxide changes. } \\
\text { A total of } 38 \text { hours of tracer concentration data were collected at three levels on the tower. }\end{array}$ \\
\hline
\end{tabular}




\begin{tabular}{|c|c|c|c|}
\hline \multicolumn{4}{|r|}{ Tropical Western Pacific } \\
\hline $\begin{array}{l}\text { September } 2005- \\
\text { November } 2010\end{array}$ & $\begin{array}{l}\text { Orbiting Carbon Observatory } \\
\text { (OCO) - FTS Validation }\end{array}$ & Ongoing & $\begin{array}{l}\text { The NASA OCO Science Team will deploy, operate, and maintain ground-based solar-viewing } \\
\text { FTS mobile laboratories at the TWP site in Darwin, Australia, to validate space-based carbon } \\
\text { dioxide retrievals. Long-term operation of both FTSs will continue through the end of the } \\
\text { OCO mission (2010). }\end{array}$ \\
\hline $\begin{array}{l}\text { June } 2006 \text { - } \\
\text { June } 2011\end{array}$ & $\begin{array}{l}\text { Geoscience Australia Con- } \\
\text { tinuous GPS Station }\end{array}$ & Ongoing & $\begin{array}{l}\text { The TWP site in Darwin is hosting a new GPS station that will form part of the Australian } \\
\text { Regional GPS Network and South Pacific GPS Network. These networks consist of more than } \\
30 \text { continuous GPS stations operating within Australia and its territories (including Antarctica) } \\
\text { and the Southwest Pacific. They support a number of different science applications, including } \\
\text { but not limited to, the maintenance of the Geospatial Reference Frame (both national and inter- } \\
\text { national), continental and tectonic plate motions, sea-level rise, and global warming. }\end{array}$ \\
\hline \multicolumn{4}{|r|}{ ARM Mobile Facility } \\
\hline $\begin{array}{l}\text { January } 2006- \\
\text { January } 2007\end{array}$ & $\begin{array}{l}\text { RAdiative Divergence using } \\
\text { AMF, GERB and AMMA } \\
\text { Stations (RADAGAST) }\end{array}$ & Completed & $\begin{array}{l}\text { The primary purpose of this 1-year deployment in Niamey, Niger, Africa, was to combine an } \\
\text { extended series of measurements from the AMF with those from satellite instrumentation to } \\
\text { provide the first well-sampled, direct estimates of the divergence of solar and infrared radiation } \\
\text { across the atmosphere. The deployment was timed to coincide with the field phases and special } \\
\text { observing periods of the African Monsoon Multidisciplinary Analyses and related experiments } \\
\text { in } 2006 \text {. }\end{array}$ \\
\hline $\begin{array}{l}\text { March } 2007- \\
\text { December } 2007\end{array}$ & $\begin{array}{l}\text { Simplified Soil Moisture } \\
\text { Probes at Black Forest During } \\
\text { COPS }\end{array}$ & In Progress & $\begin{array}{l}\text { This field campaign will attempt to close the gaps in process understanding related to Quantita- } \\
\text { tive Precipitation Forecasting by contributing comprehensive, high-quality data sets usable for } \\
\text { model validation and data assimilation. Theoretical analyses have identified the requirements } \\
\text { that measured data must meet. One of the scientific goals of COPS is to better understand } \\
\text { extreme events. Soil moisture probes used during COPS will obtain data for scientists to study } \\
\text { how saturated soil conditions can influence heavy rains by (1) providing source of water vapor } \\
\text { for precipitation, and (2) preventing precipitation from entering the ground. }\end{array}$ \\
\hline $\begin{array}{l}\text { April } 2007- \\
\text { December } 2007\end{array}$ & $\begin{array}{l}\text { Initiation of Convection and } \\
\text { the Microphysical Properties } \\
\text { of Clouds in Orographic } \\
\text { Terrain: AMF and COPS }\end{array}$ & In Progress & $\begin{array}{l}\text { This field campaign covers the deployment and operation of the AMF during the Convective } \\
\text { and Orographically Induced Precipitation Study (COPS) in the Black Forest area of Germany. } \\
\text { The campaign will examine the processes responsible for the formation and evolution of convec- } \\
\text { tive clouds in orographic terrain, the microphysical properties of orographically induced clouds } \\
\text { and how those depend on dynamics, thermodynamics, and aerosol microphysics, and how } \\
\text { convective clouds in orographic terrain can be represented in atmospheric models based on the } \\
\text { data obtained during COPS. For more information, see the Featured Field Campaigns section } \\
\text { of this report. }\end{array}$ \\
\hline $\begin{array}{l}\text { April } 2007- \\
\text { December } 2007\end{array}$ & $\begin{array}{l}\text { 90/150 MWR Profiler Radi- } \\
\text { ometer at AMF Black Forest } \\
\text { During COPS }\end{array}$ & In Progress & $\begin{array}{l}\text { This field campaign will attempt to close the gaps in the process understanding related to Quan- } \\
\text { titative Precipitation Forecasting by contributing comprehensive, high-quality data sets usable } \\
\text { for model validation and data assimilation. Theoretical analyses have identified the requirements } \\
\text { that measured data must meet. The } 90 / 150 \text { MWR data are of interest because they supplement } \\
\text { other MWR measurements in the study of total column water vapor and liquid water content. }\end{array}$ \\
\hline $\begin{array}{l}\text { April } 2007- \\
\text { December } 2007\end{array}$ & $\begin{array}{l}\text { Humidity and Temperature } \\
\text { Profiling Radiometer (HAT- } \\
\text { PRO) at Black Forest During } \\
\text { COPS }\end{array}$ & In Progress & $\begin{array}{l}\text { This field campaign will attempt to close the gaps in the process understanding related to Quan- } \\
\text { titative Precipitation Forecasting by contributing comprehensive, high-quality data sets usable } \\
\text { for model validation and data assimilation. Theoretical analyses have identified the requirements } \\
\text { that measured data must meet. The HATPRO is a type of MWR whose data can also be used to } \\
\text { determine atmospheric temperature profiles. }\end{array}$ \\
\hline $\begin{array}{l}\text { April } 2007- \\
\text { December } 2007\end{array}$ & $\begin{array}{l}\text { Micro-Rain Radar at Black } \\
\text { Forest During COPS }\end{array}$ & In Progress & $\begin{array}{l}\text { This field campaign will attempt to close the gaps in the process understanding related to Quan- } \\
\text { titative Precipitation Forecasting by contributing comprehensive, high-quality data sets usable } \\
\text { for model validation and data assimilation. Theoretical analyses have identified the requirements } \\
\text { that measured data must meet. The Micro-Rain Radar is a sophisticated rain gauge for providing } \\
\text { essential measurements of rain rate. }\end{array}$ \\
\hline
\end{tabular}




\begin{tabular}{|c|c|c|c|}
\hline May 2007 & $\begin{array}{l}35.5 \mathrm{GHz} \text { Cloud Radar } \\
\text { Comparison at Black Forest } \\
\text { During COPS }\end{array}$ & Completed & $\begin{array}{l}\text { This field campaign will attempt to close the gaps in the process understanding related to Quan- } \\
\text { titative Precipitation Forecasting by contributing comprehensive, high-quality data sets usable } \\
\text { for model validation and data assimilation. Theoretical analyses have identified the requirements } \\
\text { that measured data must meet. The } 35.5 \mathrm{GHz} \text { Radar supplements the AMF to the suite of } \\
\text { measurements with scanning capability to allow full 3D analysis of rain events. }\end{array}$ \\
\hline $\begin{array}{l}\text { May } 2007 \text { - } \\
\text { September } 2007\end{array}$ & $\begin{array}{l}\text { Coherent Doppler Wind } \\
\text { Lidar (WILI) at Black Forest } \\
\text { During COPS }\end{array}$ & Completed & $\begin{array}{l}\text { This field campaign will attempt to close the gaps in the process understanding related to Quan- } \\
\text { titative Precipitation Forecasting by contributing comprehensive, high-quality data sets usable } \\
\text { for model validation and data assimilation. Theoretical analyses have identified the requirements } \\
\text { that measured data must meet. The WILI provides the 3D character and profile of winds during } \\
\text { convective-type events. }\end{array}$ \\
\hline $\begin{array}{l}\text { May } 2007- \\
\text { September } 2007\end{array}$ & $\begin{array}{l}\text { Multi-Wavelength Raman } \\
\text { Lidar at Black Forest During } \\
\text { COPS }\end{array}$ & Completed & $\begin{array}{l}\text { This field campaign will attempt to close the gaps in the process understanding related to Quan- } \\
\text { titative Precipitation Forecasting by contributing comprehensive, high-quality data sets usable } \\
\text { for model validation and data assimilation. Theoretical analyses have identified the requirements } \\
\text { that measured data must meet. The Multi-Wavelength Raman Lidar was deployed as a means to } \\
\text { double check the MWR water vapor results. }\end{array}$ \\
\hline $\begin{array}{l}\text { June } 2007 \text { - } \\
\text { December } 2007\end{array}$ & $\begin{array}{l}\text { Cloud Microwave Validation } \\
\text { Experiment in Support of } \\
\text { CLOWD }\end{array}$ & In Progress & $\begin{array}{l}\text { Cloud property retrievals using MWRs offer a promising method for obtaining needed } \\
\text { observations of cloud liquid-water path; however, unresolved issues remain. To improve the } \\
\text { understanding of existing uncertainties in the observations and spectroscopy in the microwave } \\
\text { region, the ACRF is deploying a new } 90 / 150 \mathrm{GHz} \text { MWR with the AMF during the 9-month } \\
\text { COPS observation period. }\end{array}$ \\
\hline $\begin{array}{l}\text { March } 2007- \\
\text { December } 2007\end{array}$ & $\begin{array}{l}\text { GPS Water Vapor at Black } \\
\text { Forest During COPS }\end{array}$ & In Progress & $\begin{array}{l}\text { This field campaign will attempt to close the gaps in the process understanding related to Quan- } \\
\text { titative Precipitation Forecasting by contributing comprehensive, high-quality data sets usable } \\
\text { for model validation and data assimilation. Theoretical analyses have identified the requirements } \\
\text { that measured data must meet. The GPS Water Vapor System supplements the water vapor } \\
\text { measurements made by the MWRs and the Multi-Wavelength Raman Lidar. These additional } \\
\text { observations determine the 3D distribution of water vapor. }\end{array}$ \\
\hline $\begin{array}{l}\text { July } 2007- \\
\text { August } 2007\end{array}$ & $\begin{array}{l}\text { COPS: University of } \\
\text { Cologne Micromet Station }\end{array}$ & Completed & $\begin{array}{l}\text { This collaborative effort with the Institute of Geophysics and Meteorology of Koeln, Germany, } \\
\text { focused on the measurement of meteorological surface parameters for the determination of } \\
\text { surface fluxes with a student practicum. Using a Micromet station installed at the AMF site, the } \\
\text { goals of this campaign were for the students to learn techniques for determining surface fluxes } \\
\text { and how those fluxes relate to mechanisms regulating the total Earth system. }\end{array}$ \\
\hline $\begin{array}{l}\text { July } 2007 \text { - } \\
\text { December } 2007\end{array}$ & $\begin{array}{l}\text { ADvanced MIcrowave RAdi- } \\
\text { ometer for Rain Identification } \\
\text { (ADMIRARI) at Black Forest } \\
\text { During COPS }\end{array}$ & In Progress & $\begin{array}{l}\text { The scientific focus of this collaborative effort with the University of Bonn (Germany) was } \\
\text { on the measurements of integrated water vapor and integrated liquid water. Five months of } \\
\text { continuous measurements from the ADMIRARI will be analyzed using an optimal estimation } \\
\text { retrieval technique. The mission will provide additional insight for the understanding of the } \\
\text { onset of precipitation. }\end{array}$ \\
\hline August 2007 & $\begin{array}{l}\text { ARM Aerosol Observing sys- } \\
\text { tem (AOS) Intercomparison }\end{array}$ & Completed & $\begin{array}{l}\text { In an intercomparison effort with the AOS, scientists from Paul Scherrer Institute (PSI) of } \\
\text { Switzerland co-located a humidified nephelometer at the AMF site in Heselbach, Germany. The } \\
\text { purpose of this campaign was to assist the AOS and PSI scientists in finding uncertainties and } \\
\text { differences between the measurements and provide refinement measures for the instrumenta- } \\
\text { tion. }\end{array}$ \\
\hline \multicolumn{4}{|r|}{ Offsite Campaigns } \\
\hline Fall 2005 & $\begin{array}{l}\text { Study of Environmental } \\
\text { Arctic Change (SEARCH) } \\
\text { Data Archival }\end{array}$ & Ongoing & $\begin{array}{l}\text { NOAA is deploying a climate-monitoring site in Eureka, Canada, as part of the SEARCH } \\
\text { Program in an effort to duplicate the ACRF site in Barrow, Alaska, in terms of instrument, } \\
\text { datastreams, and data formats. Because data sets would be similar to those in the ARM and } \\
\text { SEARCH data sets, a combined archive will be used to create a comparison to facilitate Arctic } \\
\text { research. }\end{array}$ \\
\hline
\end{tabular}




\section{FY 2007 Publications}

\section{Journal Articles}

Agudelo, PA, JA Curry, CD Hoyos, and PJ Webster. 2006. “Transition between suppressed and active phases of intraseasonal oscillations in the Indo-Pacific warm pool.” Journal of Climate 19:5519-5530.

Benedict, JJ, and DA Randall. 2007. “Observed characteristics of the MJO relative to maximum rainfall.” Journal of Atmospheric Sciences 64:2332-2354.

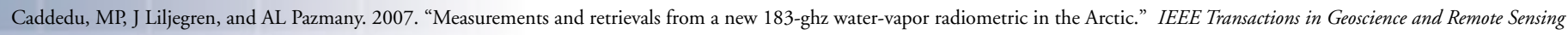
45:2207-2215.

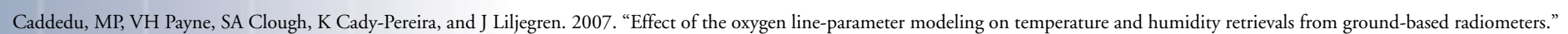
IEEE Transactions in Geoscience and Remote Sensing 45:2216-2223.

Chiriaco, M, H Chepfer, P Minnis, M Haeffelin, S Platnick, D Baumgardner, P Dubuisson, M McGill, V Noël, J Pelon, D Spangenberg, S Sun-Mack, and G Wind. 2007. “Comparison of

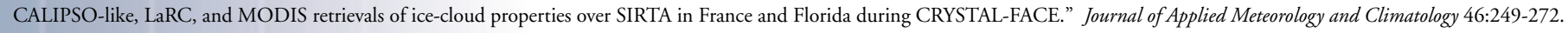

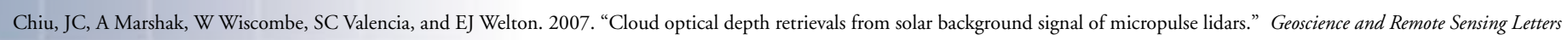
4: $456-460$.

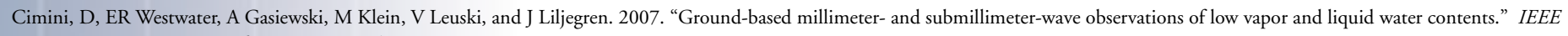
Transactions on Geoscience and Remote Sensing 45:2169-2180.

Comstock, JM, R d'Entremont, D DeSlover, GG Mace, SY Matrosov, SA McFarlane, P Minnis, D Mitchell, K Sassen, MD Shupe, DD Turner, and Z Wang. 2007. "An intercomparison of microphysical retrieval algorithms for upper-tropospheric ice clouds." Bulletin of the American Meteorological Society 88: 191-204.

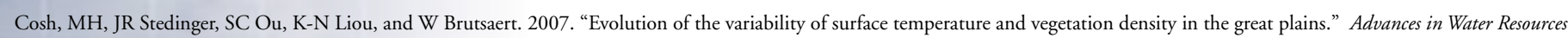
30:1094-1104.

Del Genio, AD, M-S Yao, and J Jonas. 2007. “Will moist convection be stronger in a warmer climate?” Geophysical Research Letters L16703, doi:10.1029/2007GL030525.

DeMott, CA, DA Randall, and M Khairoutdinov. 2007. “Convective precipitation variability as a tool for general circulation model analysis.” Journal of Climate 20:91-112.

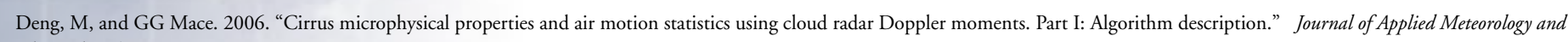
Climatology 45:1690-1709.

Dong, X, B Xi, and P Minnis. 2006. “Observational evidence of changes in water vapor, clouds, and radiation at the ARM SGP site.” Geophysical Research Letters 33, L19818, doi:10.1029/ 2006 GL027132.

Flynn, CJ, A Mendoza, Y Zheng, and S Mathur. 2007. “Novel polarization-sensitive micropulse lidar measurement technique.” Optics Express 15: 2785-2790.

Ghan, S, and SE Schwartz. 2007. "Aerosol properties and processes: A path from field and laboratory measurements to global climate models." Bulletin of the American Meteorological Society 88: $1059-1083$.

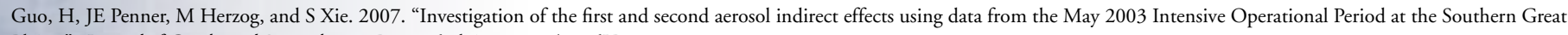
Plains." Journal of Geophysical Research 112, D15206, doi:10.1029/2006JD007173.

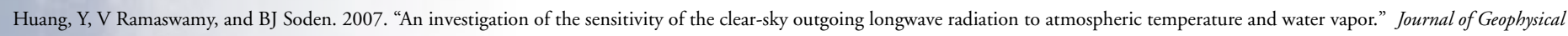
Research 112, D05104, doi:10.1029/2005JD006906.

Hume, T, and C Jakob. 2007. “Ensemble single column model validation in the tropical western Pacific.” Journal of Geophysical Research 112, D10206, doi:10.1029/2006JD008018.

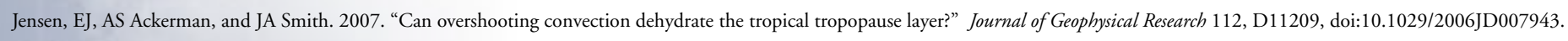

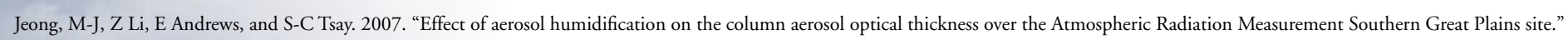
Journal of Geophysical Research 112, D10202, doi:10.1029/2006JD007176.

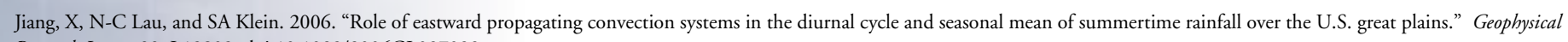
Research Letters 33, L19809, doi:10.1029/2006GL027022.

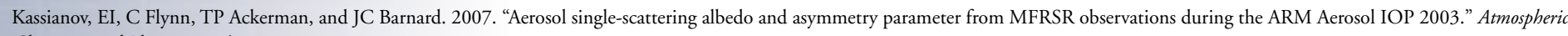
Chemistry and Physics 7: 3341-3351.

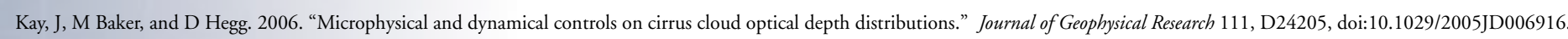

Kay, J, M Baker, and D Hegg. 2007. "Physical controls on orographic cirrus inhomogeneity." Atmospheric Chemistry and Physics 7: $3771-3781$.

Kelly, JT, CC Chuang, and AS Wexler. 2007. “Influence of dust composition on cloud droplet formation.” Atmospheric Environment 41: $2904-2916$.

Khairoutdinov, M, and D Randall. 2006. "High-resolution simulation of shallow-to-deep convection transition over land.” Journal of Atmospheric Sciences 63:3421-3436.

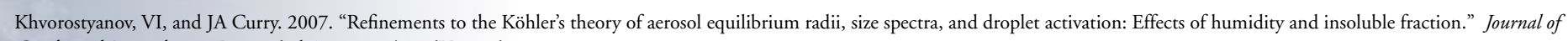
Geophysical Research 112, D05206, doi:10.1029/2006JD007672.

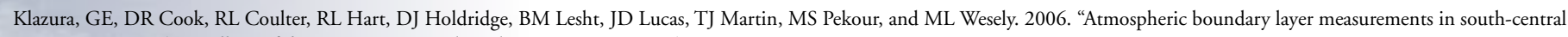
Kansas, 1997-2004." Bulletin of the American Meteorological Society 87:1319-1324.

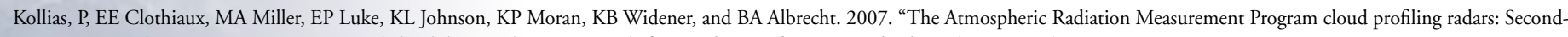
generation sampling strategies, processing, and cloud data products.” Journal of Atmospheric and Oceanic Technology 24:1199-1214.

Liu, X, JE Penner, SJ Ghan, and M Wang. 2007. “Inclusion of ice microphysics in the NCAR Community Atmospheric Model Version 3 (CAM3).” Journal of Climate 20:4526-4547.

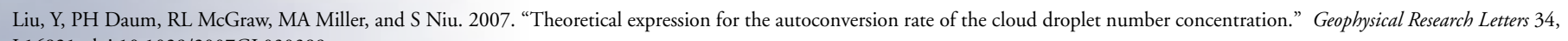
L16821, doi:10.1029/2007GL030389. 


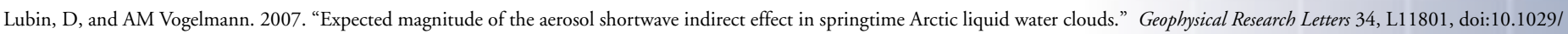
2006GL028750.

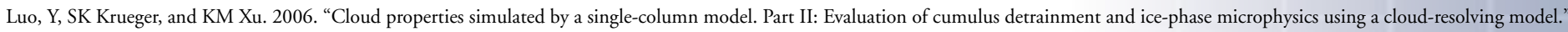
Journal of Atmospheric Sciences 63:2831-2847.

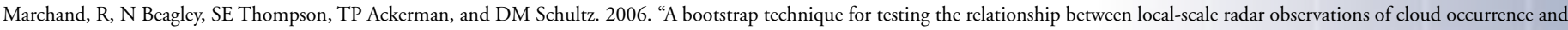
large-scale atmospheric fields." Journal of Atmospheric Sciences 63:2813-2830.

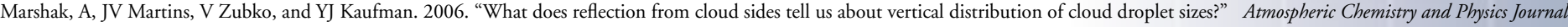
6: $5295-5305$.

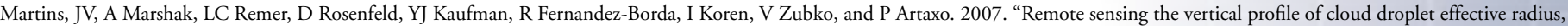
thermodynamic phase, and temperature." Atmospheric Chemistry and Physics Discussions 7: 4481-4591.

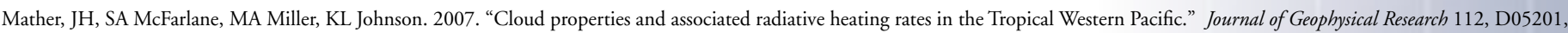
doi:10.1029/2006JD007555.

Matrosov, SY. 2007. "Modeling backscatter properties of snowfall at millimeter wavelengths.” Journal of Atmospheric Sciences 64:1727-1736.

Matrosov, SY, PT May, and MD Shupe. 2006. "Rainfall profiling using Atmospheric Radiation Measurement Program vertically pointing 8-mm wavelength radars." Journal of Atmospheric and Oceanic Technology 23:1478-1491.

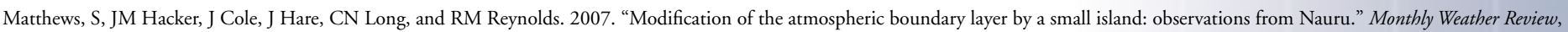
Vol. 135, No. 3, pages 891-905.

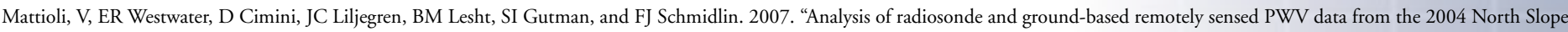
of Alaska Arctic Winter Radiometric Experiment.” Journal of Atmospheric and Oceanic Technology 24:415-431.

May, PT, and A Ballinger. 2007. "The statistical characteristics of convective cells in a monsoon regime (Darwin, Northern Australia)." Monthly Weather Review 135:82-92.

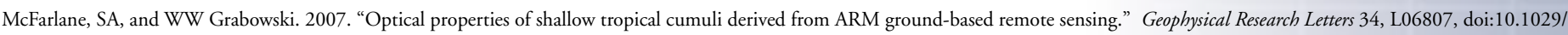
2006 GL029207.

McFarlane, SA, JH Mather, and TP Ackerman. 2007. "Analysis of tropical radiative heating profiles: A comparison of models and observations." Journal of Geophysical Research 112, D14218, doi:10.1029/2006JD008290.

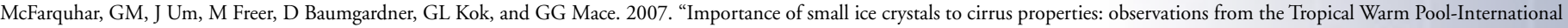
Cloud Experiment (TWP-ICE).” Geophysical Research Letters 34, L13803, doi:10.1029/2007GL029865.

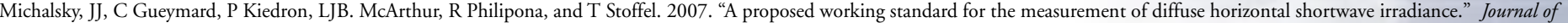
Geophysical Research 112, D16112, doi:10.1029/2007JD008651.

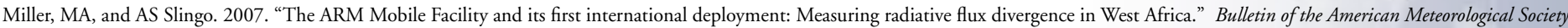
88: $1229-1244$.

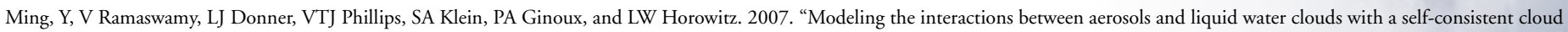
scheme in a general circulation model.” Journal of Atmospheric Sciences 64:1189-1209.

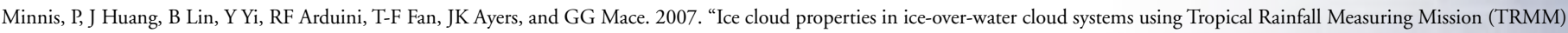
visible and infrared scanner and TRMM microwave imager data." Journal of Geophysical Research 112, D06206, doi:10.1029/2006JD007626.

Mitchell, DL, AJ Baran, WP Arnott, and C Schmitt. 2006. “Testing and comparing the modified anomalous diffraction approximation.” Journal of Atmospheric Sciences 63:2948-2962.

Morcette, JJ, HW Barker, MJ Iacono, G Mozdynski, R Pincus, D Salmond, and S Serrar. 2007. “A new radiation package: McRad.” ECMWF Newsletter 112:22-32.

Naud, CM, AD Del Genio, and M Bauer. 2006. "Observational constraints on the cloud thermodynamic phase in midlatitude storms." Journal of Climate 19:5273-5288.

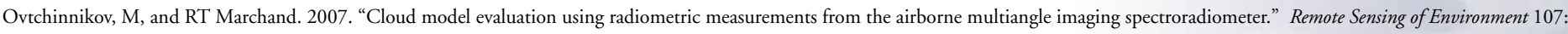
$185-193$.

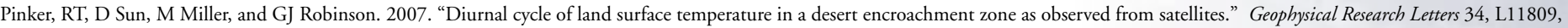
doi:10.1029/2007GL030186.

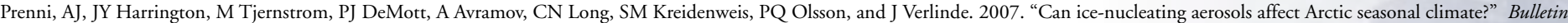
of the American Meteorological Society 88: 541-550.

Sassen, K, and VI Khorostyanov. 2007. "Microphysical and radiative properties of mixed-phase altocumulus: A model evaluation of glaciation effects." Atmospheric Research 84: 390 -398.

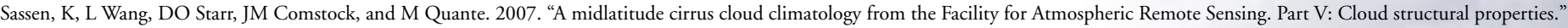
Journal of Atmospheric Sciences 64:2483-2501.

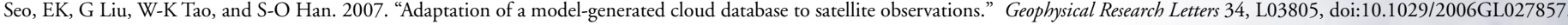

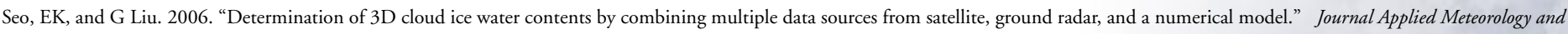
Climatology 45:1494-1504.

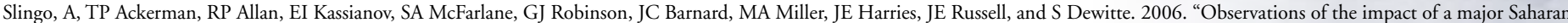
dust storm on the atmospheric radiation balance." Geophysical Research Letters 33, L24817, doi:10.1029/2006GL027869.

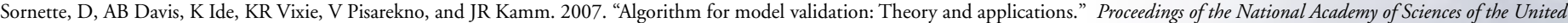
States of America 104:6562-6567.

Stephens, GL, and NB Wood. 2007. "Properties of tropical convection observed by millimeter-wave radar systems.” Monthly Weather Review 135:821-842.

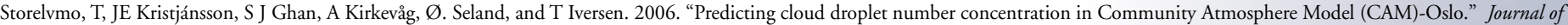
Geophysical Research 111, D24208, doi:10.1029/2005JD006300. 
Tselioudis, G, and P Kollias. 2007. "Evaluation of ECMWF cloud type simulations at the ARM Southern Great Plains site using a new cloud type climatology." Geophysical Research Letters 34, L03803, doi:10.1029/2006GL027314.

Turner, DD. 2007. “Improved ground-based liquid water path retrievals using a combined infrared and microwave approach." Journal of Geophysical Research 112, D15204, doi:10.1029/ 2007JD008530.

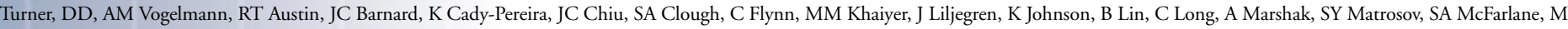

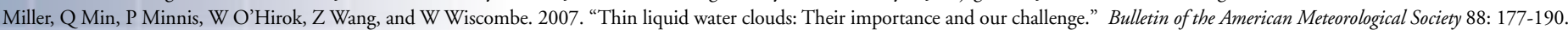

Um, J, and GM McFarquhar. 2007. "Single-scattering properties of aggregates of bullet rosettes in cirrus." Journal of Applied Meteorology and Climatology 46:757-775.

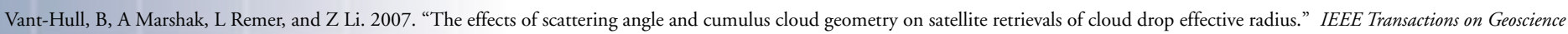
and Remote Sensing 45:1039-1045.

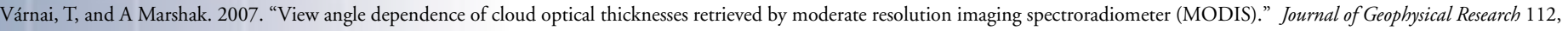
D06203, doi:10.1029/2005JD006912.

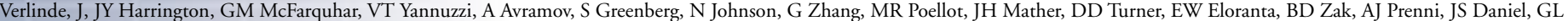

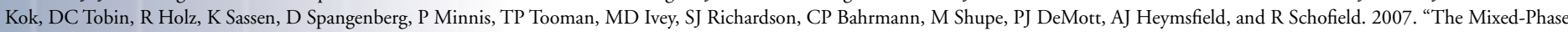
Arctic Cloud Experiment." Bulletin of the American Meteorological Society 88: 205-221.

Wang, J. 2007. "Effects of spatial and temporal variations in aerosol properties on mean cloud albedo." Journal of Geophysical Research 112, D16201, doi:10.1029/2007JD008565.

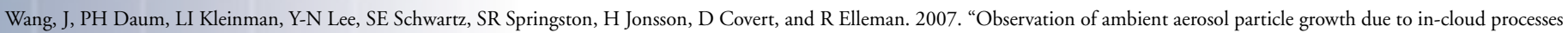
within boundary layers." Journal of Geophysical Research 112, D14207, doi:10.1029/2006JD007989.

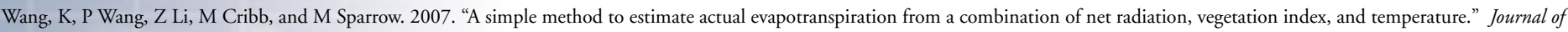
Geophysical Research 112, D15107, doi:10.1029/2006JD008351.

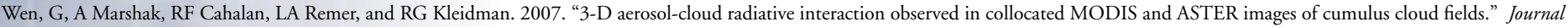
of Geophysical Research 112, D13204, doi:10.1029/2006JD008267.

Williamson, DL, and JG Olson. 2007. "A comparison of forecast errors in CAM2 and CAM3 at the ARM Southern Great Plains site." Journal of Climate 20:4572-4585.

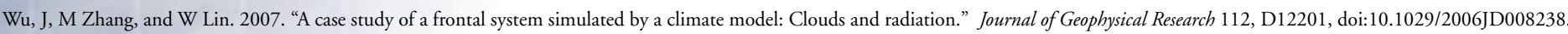
Wu, X, XZ Liang, and S Park. 2007. “Cloud-resolving model simulations over the ARM SGP.” Monthly Weather Review 135:2841-2853

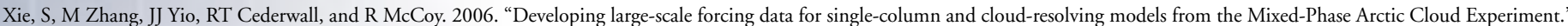
Journal of Geophysical Research 111, D19104, doi:10.1029/2005JD006950.

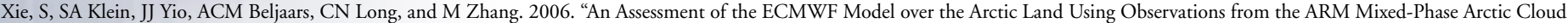
Experiment.” Journal of Geophysical Research 111, D05107, doi:10.1029/2005JD006509.

\section{Conference Proceedings}

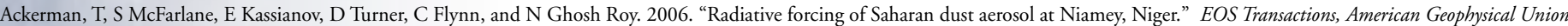
$(A G U)$ 87(52) Fall Meeting Supplement, Abstract A24C-08, American Geophysical Union (AGU), San Francisco, California.

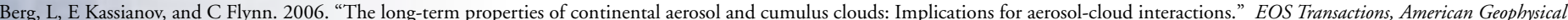
Union (AGU) 87(52) Fall Meeting Supplement, Abstract A33B-1008, American Geophysical Union (AGU), San Francisco, California.

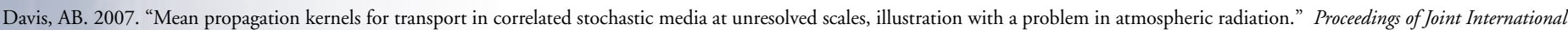
Topical Meeting on Mathematics Computation and Supercomputing in Nuclear Applications MC SNA 2007, Monterey, California.

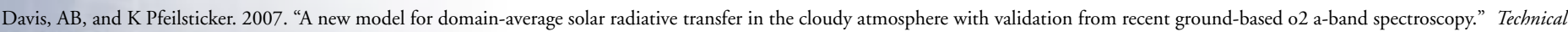
Digest of the OSA Hyperspectral Imaging and Sounding of the Environment (HISE) Topical Meeting, Santa Fe, New Mexico.

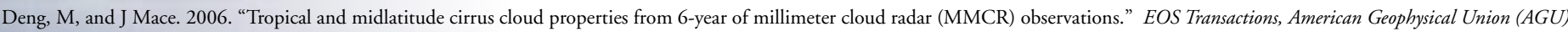
87(52), Fall Meeting Supplement, Abstract A52C-07, American Geophysical Union (AGU), San Francisco, California.

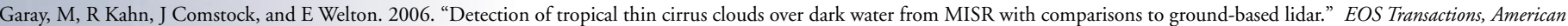
Geophysical Union (AGU) 87(52), Fall Meeting Supplement, Abstract A41A-0013, American Geophysical Union (AGU), San Francisco, California.

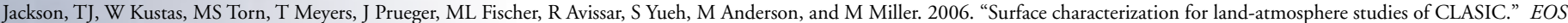
Transactions, American Geophysical Union (AGU) 87(52), Fall Meeting Supplement, Abstract H13H-04, American Geophysical Union (AGU), San Francisco, California.

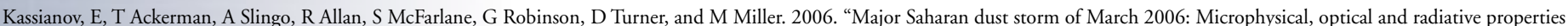

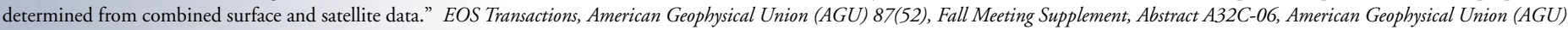
San Francisco, California.

Long, CN, JC Barnard, KL Gaustad, DD Turner, and TP Ackerman. 2007. "Determination of cloud properties and the complete net surface radiative cloud forcing from surface radiation measurements.” Proceedings of European Geosciences Union (EGU) General Assembly, European Geosciences Union (EGU), Vienna, Austria.

Lubin, D, and A Vogelmann. 2006. "A climatologically significant aerosol longwave indirect effect in the Arctic." EOS Transactions, American Geophysical Union (AGU) 87(52), Fall Meeting Supplement, Abstract A32A-08, American Geophysical Union (AGU), San Francisco, California.

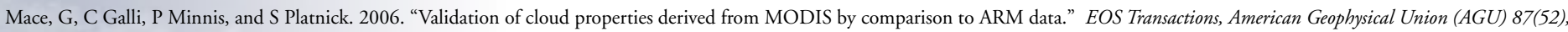
Fall Meeting Supplement, Abstract A51H-06 INVITED, American Geophysical Union (AGU), San Francisco, California.

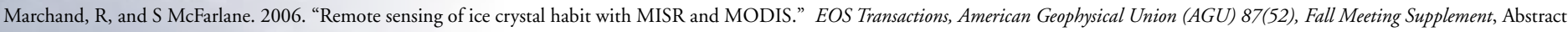
A33C-1020, American Geophysical Union (AGU), San Francisco, California.

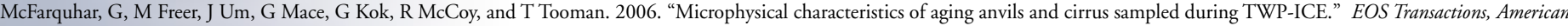
Geophysical Union (AGU) 87(52), Fall Meeting Supplement, Abstract A43E-05 INVITED, American Geophysical Union (AGU), San Francisco, California. 
Minnett, P, J Hanafin, M Szczodrak, E Key, M Izaguirre, and O Brown. 2006. “Scientific applications of the marine-atmospheric emitted radiance interferometer." EOS Transactions, American Geophysical Union (AGU) 87(52), Fall Meeting Supplement, Abstract A21D-0847, American Geophysical Union (AGU), San Francisco, California.

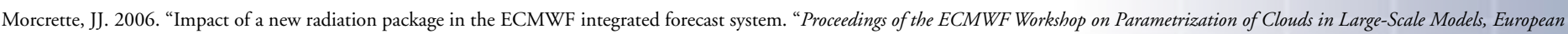
Centre for Medium-Range Weather Forecasts (ECMWF), Shinfield Park, Reading.

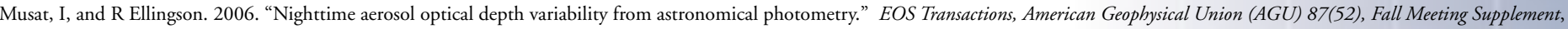
Abstract A13B-0901, American Geophysical Union (AGU), San Francisco, California

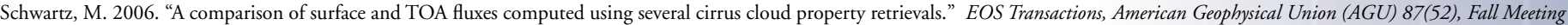
Supplement, Abstract A33C-1029, American Geophysical Union (AGU), San Francisco, California.

Somerville, R, and S Iacobellis. 2006. "Impacts of improved cloud microphysics in GCM simulations.” EOS Transactions, American Geophysical Union (AGU) 87(52), Fall Meeting Supplement, Abstract A31E-02, American Geophysical Union (AGU), San Francisco, California.

Su, W, E Dutton, CN Long, and W Wiscombe. 2007. "A plan to improve the broadband radiative measurement accuracy at AmeriFlux sites." AmeriFlux Science Team Meeting, AmeriFlux, Boulder, Colorado.

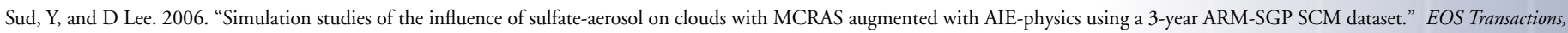
American Geophysical Union (AGU) 87(52), Fall Meeting Supplement, Abstract A13C-0940, American Geophysical Union (AGU), San Francisco, California.

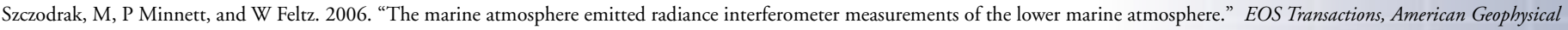
Union (AGU) 87(52), Fall Meeting Supplement, Abstract A21D-0848, American Geophysical Union (AGU), San Francisco, California

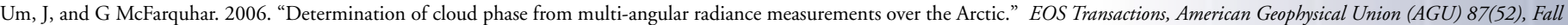
Meeting Supplement, Abstract A13B-0912, American Geophysical Union (AGU), San Francisco, California.

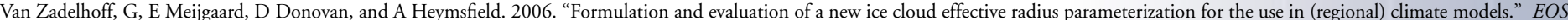
Transactions, American Geophysical Union (AGU) 87(52), Fall Meeting Supplement, Abstract A51H-02, American Geophysical Union (AGU), San Francisco, California.

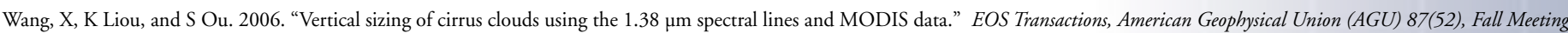
Supplement, Abstract A13B-0911, American Geophysical Union (AGU), San Francisco, California.

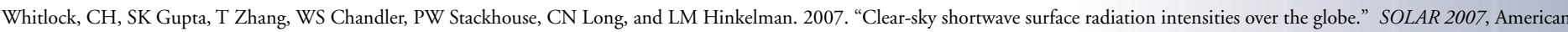
Solar Energy Society (ASES), Cleveland, Ohio.

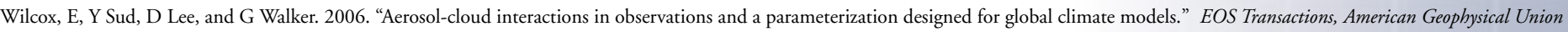
(AGU) 87(52), Fall Meeting Supplement, Abstract A33B-0977, American Geophysical Union (AGU), San Francisco, California.

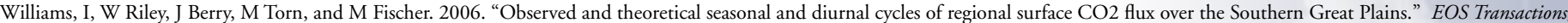
American Geophysical Union (AGU) 87(52), Fall Meeting Supplement, Abstract B51C-0334, American Geophysical Union (AGU), San Francisco, California.

Yue, Q, K Liou, and Y Gu. 2006. "Investigation of the radiative forcings of thin cirrus in the tropical atmosphere using AIRS/ARM data." EOS Transactions, American Geophysical Union (AGU) 87(52), Fall Meeting Supplement, Abstract A13B-0900, American Geophysical Union (AGU), San Francisco, California.

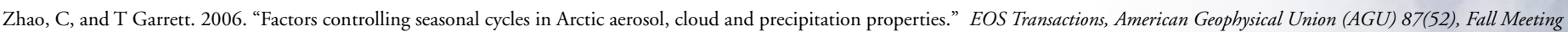
Supplement, Abstract A32A-07, American Geophysical Union (AGU), San Francisco, California.

\section{Conference Presentation Abstracts}

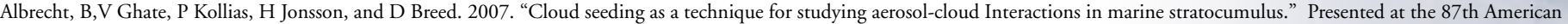
Meteorological Society (AMS) Meeting, San Antonio, Texas.

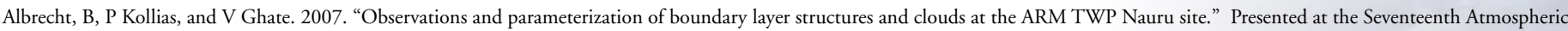
Radiation Measurement (ARM) Science Team Meeting, Monterey, California.

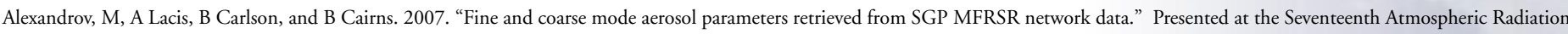
Measurement (ARM) Science Team Meeting, Monterey, California

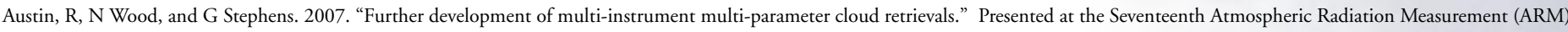
Science Team Meeting, Monterey, California.

Ayers, J, P Minnis, M Khaiyer, D Spangenberg, R Palikonda, L Nguyen, M Nordeen, S Sun-Mack, Q Trepte, and M Streibel. 2007. "Comparison of TWP-ICE and SCOUT-03 field campaign aircraft and satellite derived cloud properties.” Presented at the Seventeenth Atmospheric Radiation Measurement (ARM) Science Team Meeting, Monterey, California.

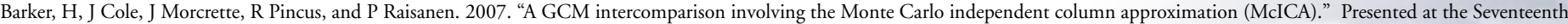
Atmospheric Radiation Measurement (ARM) Science Team Meeting, Monterey, California.

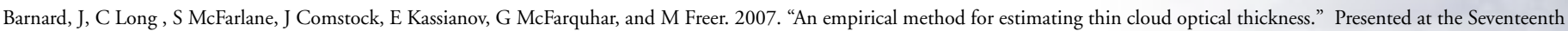
Atmospheric Radiation Measurement (ARM) Science Team Meeting, Monterey, California.

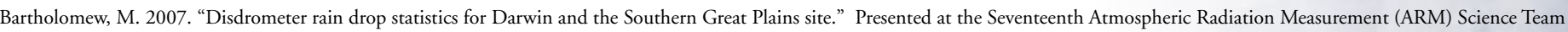
Meeting, Monterey, California.

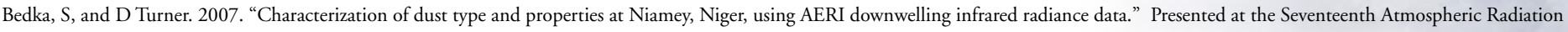
Measurement (ARM) Science Team Meeting, Monterey, California.

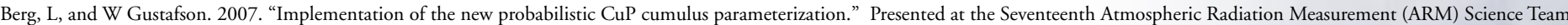
Meeting, Monterey, California.

Beus, S, N Keck, and M Macduff. 2007. "Data system metrics and reporting.” Presented at the Seventeenth Atmospheric Radiation Measurement (ARM) Science Team Meeting, Monterey, California.

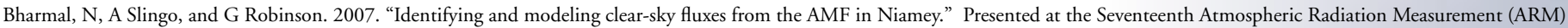
Science Team Meeting, Monterey, California. 


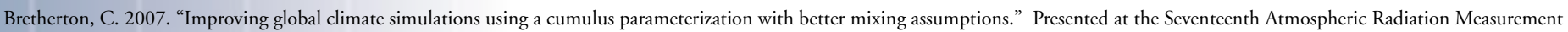
(ARM) Science Team Meeting, Monterey, California.

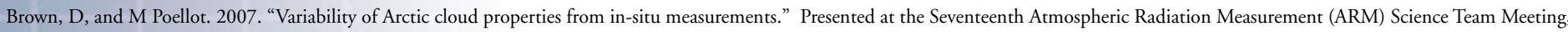
Monterey, California.

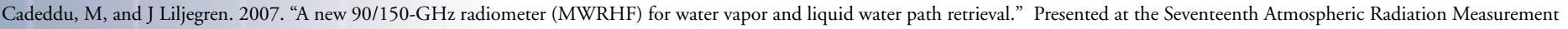
(ARM) Science Team Meeting, Monterey, California.

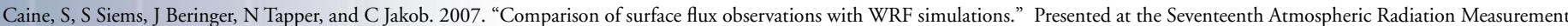
(ARM) Science Team Meeting, Monterey, California.

Cairns, B, A Lacis, M Alexandrov, B Carlson, and B Schmid. 2007. "Observed surface reflectance distributions in the Southern Great Plains during ALIVE.” Presented at the Seventeenth Atmospheric Radiation Measurement (ARM) Science Team Meeting, Monterey, California.

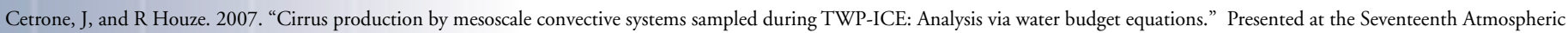
Radiation Measurement (ARM) Science Team Meeting, Monterey, California.

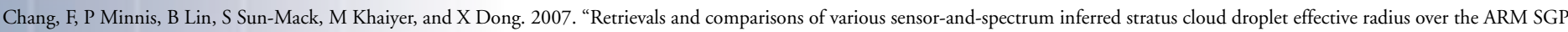
CART site.” Presented at the Seventeenth Atmospheric Radiation Measurement (ARM) Science Team Meeting, Monterey, California.

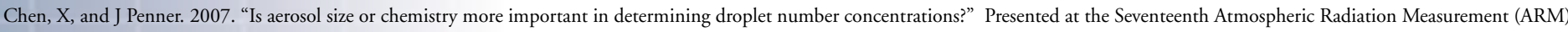
Science Team Meeting, Monterey, California.

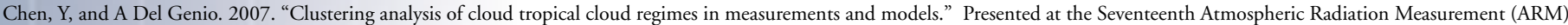
Science Team Meeting, Monterey, California.

Cheng, A, and K Xu. 2007. "Comparison of low-order and third-order turbulence closures in the simulation of shallow cumulus clouds." Presented at the Seventeenth Atmospheric Radiation Measurement (ARM) Science Team Meeting, Monterey, California.

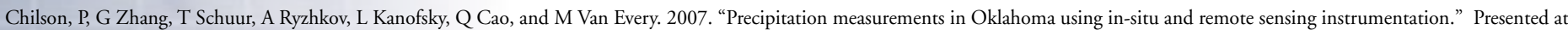
the Seventeenth Atmospheric Radiation Measurement (ARM) Science Team Meeting, Monterey, California.

Choudhury, S. 2007. "Linux software to collect from new Campbell data logger.” Presented at the Seventeenth Atmospheric Radiation Measurement (ARM) Science Team Meeting, Monterey, California.

Chuang, C, S Chin, S Xie, and J Kelly. 2007. "Exploring the multi-scale aerosol/cloud interactions from ARM measurements to global modeling." Presented at the Seventeenth Atmospheric Radiation Measurement (ARM) Science Team Meeting, Monterey, California.

Cialella, A, C Bates, R Wagener, and R Jundt. 2007. "Google and GIS integrated on the ARM website: A work in progress." Presented at the Seventeenth Atmospheric Radiation Measurement (ARM) Science Team Meeting, Monterey, California.

Coddington, O, K Schmidt, and P Pilewskie. 2007. “Spatial variability and error analysis of spectral surface albedo measured during MILAGRO.” Presented at the Seventeenth Atmospheric Radiation Measurement (ARM) Science Team Meeting, Monterey, California.

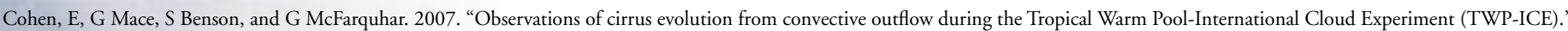
Presented at the Seventeenth Atmospheric Radiation Measurement (ARM) Science Team Meeting, Monterey, California.

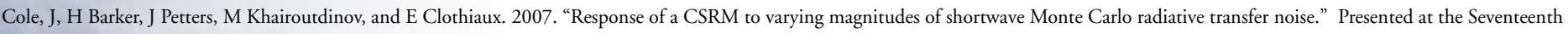
Atmospheric Radiation Measurement (ARM) Science Team Meeting, Monterey, California.

Collins, DR. 2007. “The Atmospheric Radiation Measurement Program tandem differential mobility analyzer: Instrument description and summary of 1 st year of data." Presented at the 87th American Meteorological Society (AMS) Meeting, San Antonio, Texas.

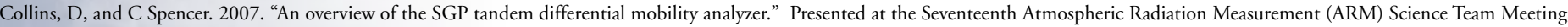
Monterey, California.

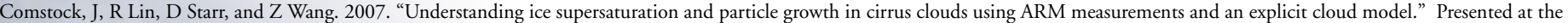
Seventeenth Atmospheric Radiation Measurement (ARM) Science Team Meeting, Monterey, California.

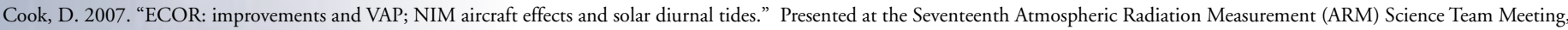
Monterey, California.

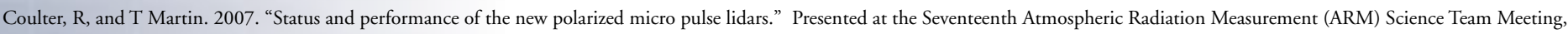
Monterey, California.

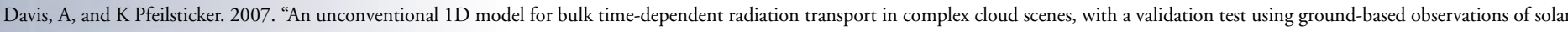
photon path length statistics." Presented at the Seventeenth Atmospheric Radiation Measurement (ARM) Science Team Meeting, Monterey, California.

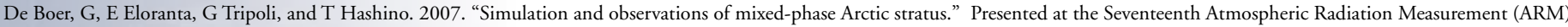
Science Team Meeting, Monterey, California.

Delamere, J, S Clough, E Mlawer, J Moncet, V Payne, and D Turner. 2007. "Improved understanding of far-infrared radiative processes using NSA ACRF measurements." Presented at the Seventeenth Atmospheric Radiation Measurement (ARM) Science Team Meeting, Monterey, California.

Demott, C. 2007. “Stratocumulus clouds in a multiscale modeling framework.” Presented at the Seventeenth Atmospheric Radiation Measurement (ARM) Science Team Meeting, Monterey, California.

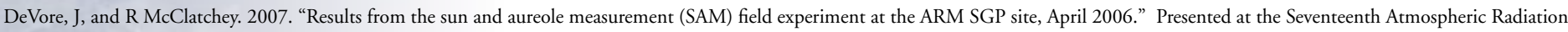
Measurement (ARM) Science Team Meeting, Monterey, California.

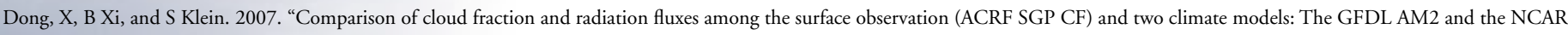
CAM3 forecast data.” Presented at the Seventeenth Atmospheric Radiation Measurement (ARM) Science Team Meeting, Monterey, California.

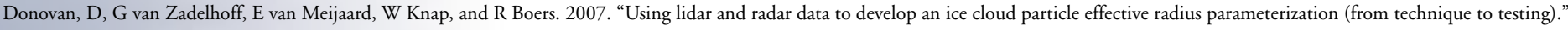
Presented at the 87 th American Meteorological Society (AMS) Meeting, San Antonio, Texas. 


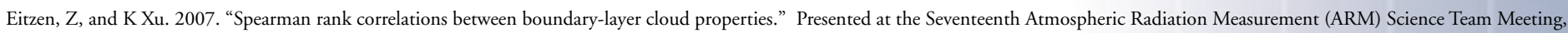
Monterey, California.

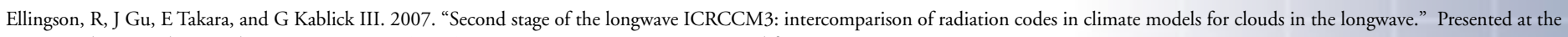
Seventeenth Atmospheric Radiation Measurement (ARM) Science Team Meeting, Monterey, California.

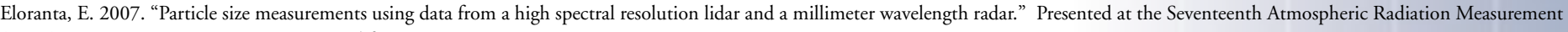
(ARM) Science Team Meeting, Monterey, California.

Evans, W, and T Dunkerton. 2007. "Investigation of hurricane precipitation coverage with CloudSat and its impact on the absorption of solar NIR radiation." Presented at the Seventeenth Atmospheric Radiation Measurement (ARM) Science Team Meeting, Monterey, California.

Ferrare, R, D Turner, M Clayton, D Petty, C Flynn, and B Schmid. 2007. "Aerosol and water vapor measurements acquired by the upgraded SGP Raman lidar during ALIVE.” Presented at the Seventeenth Atmospheric Radiation Measurement (ARM) Science Team Meeting, Monterey, California.

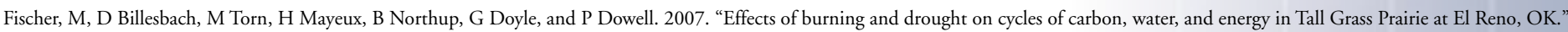
Presented at the Seventeenth Atmospheric Radiation Measurement (ARM) Science Team Meeting, Monterey, California.

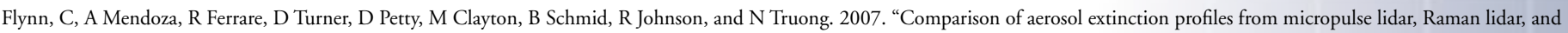

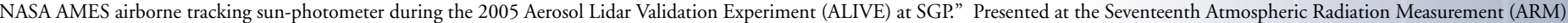
Science Team Meeting, Monterey, California.

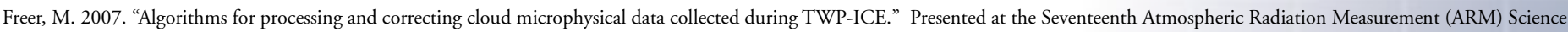
Team Meeting, Monterey, California.

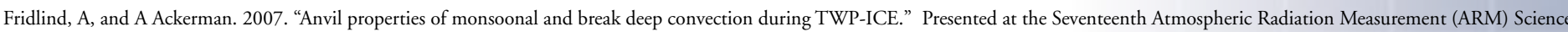
Team Meeting, Monterey, California.

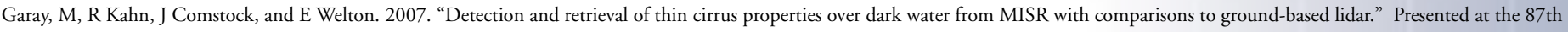
American Meteorological Society (AMS) Meeting, San Antonio, Texas.

Gaustad, K, and C Long. 2007. "Estimating broadband and spectral surface albedo using ARM data." Presented at the Seventeenth Atmospheric Radiation Measurement (ARM) Science Team Meeting, Monterey, California.

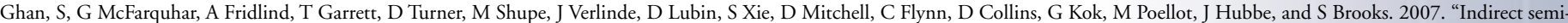
direct aerosol campaign.” Presented at the Seventeenth Atmospheric Radiation Measurement (ARM) Science Team Meeting, Monterey, California.

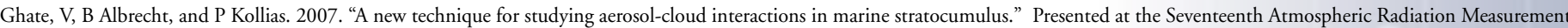
(ARM) Science Team Meeting, Monterey, California.

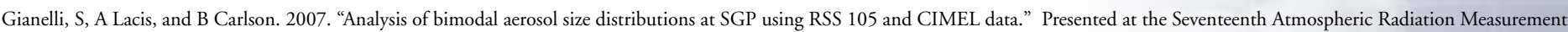
(ARM) Science Team Meeting, Monterey, California.

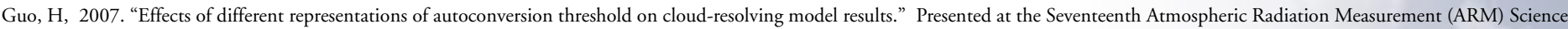
Team Meeting, Monterey, California.

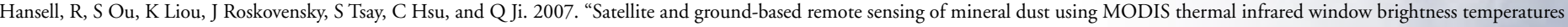
and AERI spectra." Presented at the Seventeenth Atmospheric Radiation Measurement (ARM) Science Team Meeting, Monterey, California.

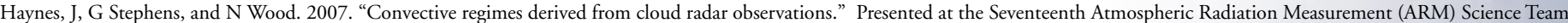
Meeting, Monterey, California.

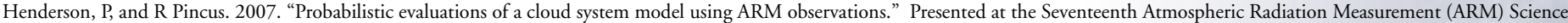
Team Meeting, Monterey, California.

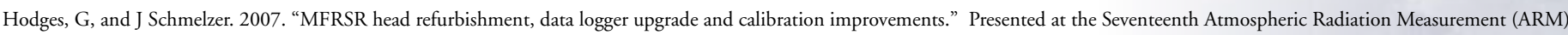
Science Team Meeting, Monterey, California.

Horvath, A, and B Soden. 2007. "Lagrangian diagnostics of tropical deep convection and its effect upon upper tropospheric humidity." Presented at the Seventeenth Atmospheric Radiation Measurement (ARM) Science Team Meeting, Monterey, California.

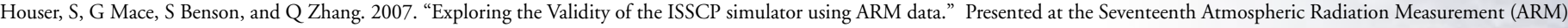
Science Team Meeting, Monterey, California.

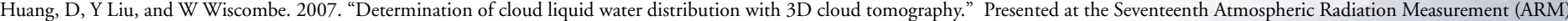
Science Team Meeting, Monterey, California.

Hudson, J. 2007. “CCN spectral measurements during MASE.” Presented at the Seventeenth Atmospheric Radiation Measurement (ARM) Science Team Meeting, Monterey, California.

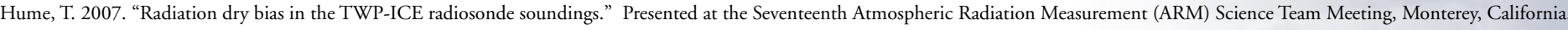

Iacono, M. 2007. "Evaluating water vapor in the NCAR CAM3 climate model with RRTMG/McICA using modeled and observed AIRS spectral radiances." Presented at the Seventeenth Atmospheric Radiation Measurement (ARM) Science Team Meeting, Monterey, California.

Ivanova, K, and T Ackerman. 2007. "An attempt to distinguish dynamical and microphysical contributions to the radiative properties of cirrus clouds at the ACRF SGP site." Presented at the Seventeenth Atmospheric Radiation Measurement (ARM) Science Team Meeting, Monterey, California.

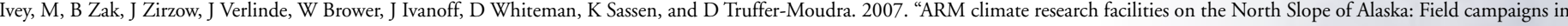
2007, new facilities, and the International Polar Year." Presented at the Seventeenth Atmospheric Radiation Measurement (ARM) Science Team Meeting, Monterey, California.

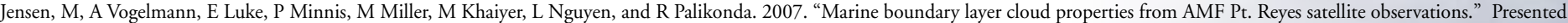
at the Seventeenth Atmospheric Radiation Measurement (ARM) Science Team Meeting, Monterey, California.

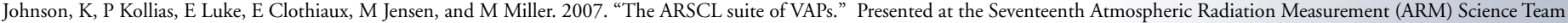
Meeting, Monterey, California. 


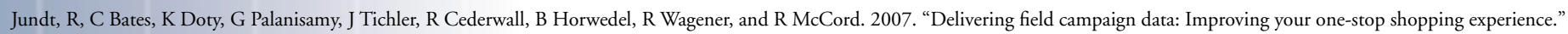
Presented at the Seventeenth Atmospheric Radiation Measurement (ARM) Science Team Meeting, Monterey, California.

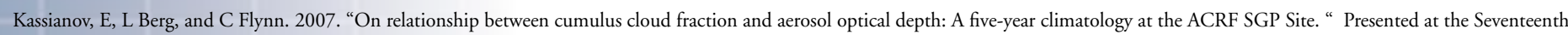
Atmospheric Radiation Measurement (ARM) Science Team Meeting, Monterey, California.

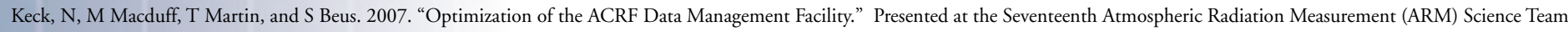
Meeting, Monterey, California.

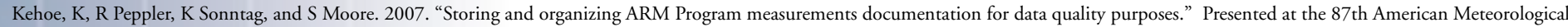
Society (AMS) Meeting, San Antonio, Texas.

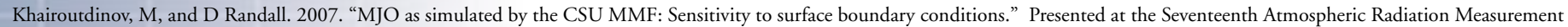
(ARM) Science Team Meeting, Monterey, California.

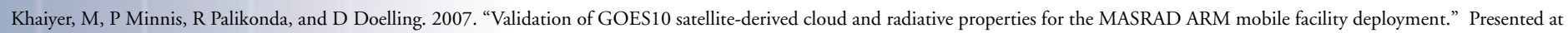
the Seventeenth Atmospheric Radiation Measurement (ARM) Science Team Meeting, Monterey, California.

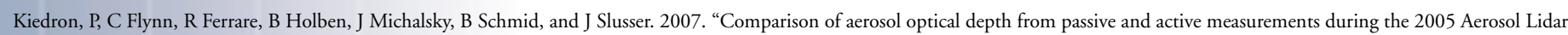
Validation Experiment (ALIVE) at SGP.” Presented at the Seventeenth Atmospheric Radiation Measurement (ARM) Science Team Meeting, Monterey, California.

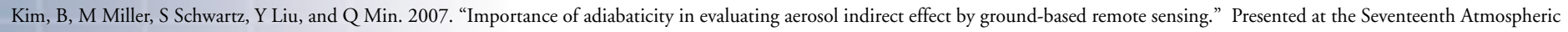
Radiation Measurement (ARM) Science Team Meeting, Monterey, California.

Knyazikhin, Y, A Marshak, J Chiu, D Huang, W Wiscombe, and P Pilewskie. 2007. "A new approach to interpret measurements of spectral surface reflectance around ACRF Central Facility." Presented at the Seventeenth Atmospheric Radiation Measurement (ARM) Science Team Meeting, Monterey, California.

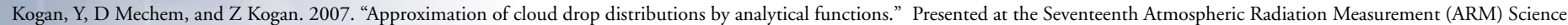
Team Meeting, Monterey, California.

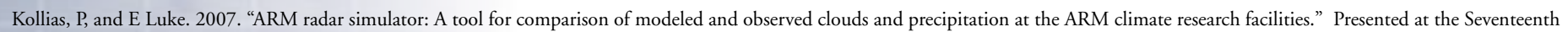
Atmospheric Radiation Measurement (ARM) Science Team Meeting, Monterey, California.

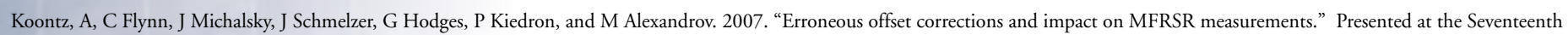
Atmospheric Radiation Measurement (ARM) Science Team Meeting, Monterey, California.

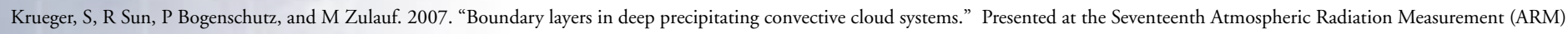
Science Team Meeting, Monterey, California.

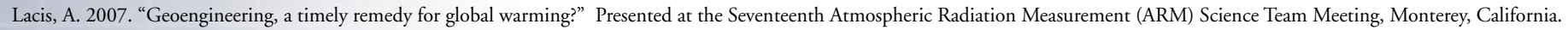

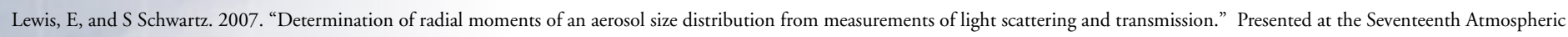
Radiation Measurement (ARM) Science Team Meeting, Monterey, California.

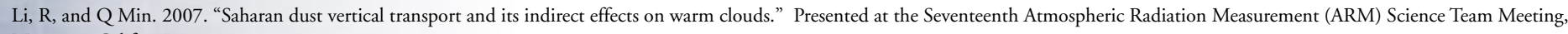
Monterey, California.

Li, Z, and G Stephens. 2007. “ARM Mobile Facility deployment in China 2008: Aerosol indirect effects under a hazy environment." Presented at the Seventeenth Atmospheric Radiation Measurement (ARM) Science Team Meeting, Monterey, California.

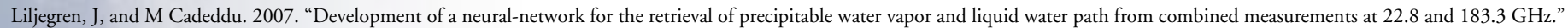
Presented at the Seventeenth Atmospheric Radiation Measurement (ARM) Science Team Meeting, Monterey, California.

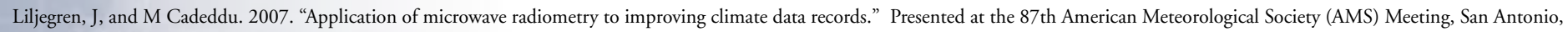
Texas.

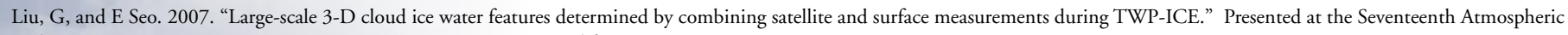
Radiation Measurement (ARM) Science Team Meeting, Monterey, California.

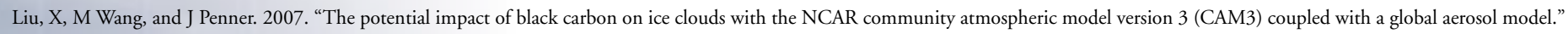
Presented at the Seventeenth Atmospheric Radiation Measurement (ARM) Science Team Meeting, Monterey, California.

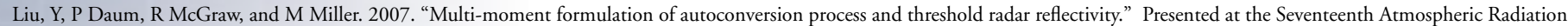
Measurement (ARM) Science Team Meeting, Monterey, California.

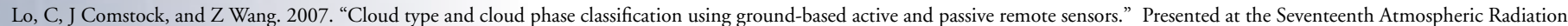
Measurement (ARM) Science Team Meeting, Monterey, California.

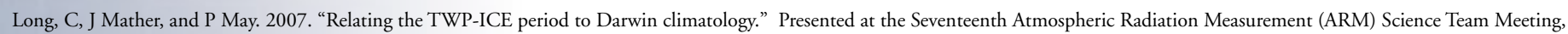
Monterey, California.

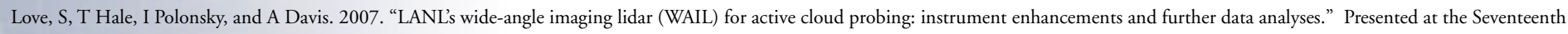
Atmospheric Radiation Measurement (ARM) Science Team Meeting, Monterey, California.

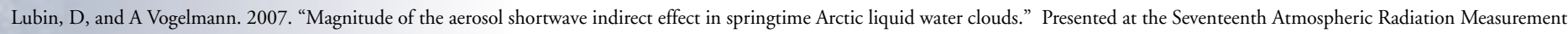
(ARM) Science Team Meeting, Monterey, California.

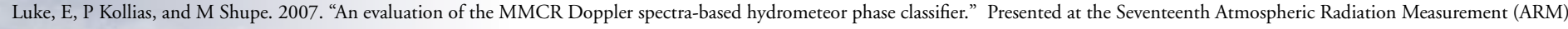
Science Team Meeting, Monterey, California.

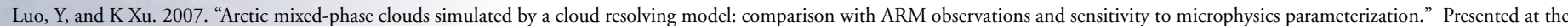
Seventeenth Atmospheric Radiation Measurement (ARM) Science Team Meeting, Monterey, California.

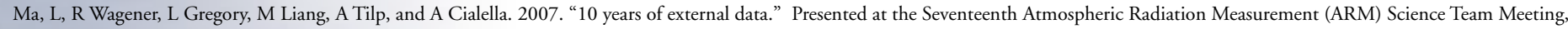
Monterey, California. 


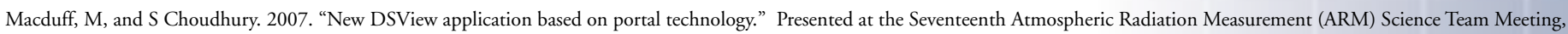
Monterey, California.

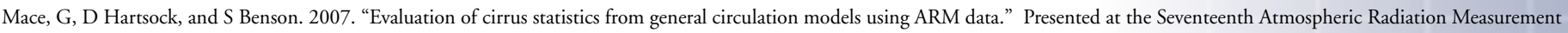
(ARM) Science Team Meeting, Monterey, California.

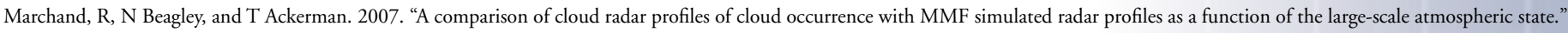
Presented at the Seventeenth Atmospheric Radiation Measurement (ARM) Science Team Meeting, Monterey, California.

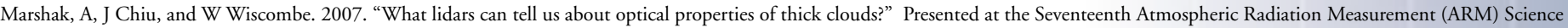
Team Meeting, Monterey, California.

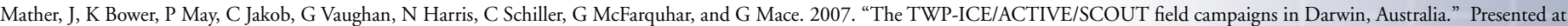
the Seventeenth Atmospheric Radiation Measurement (ARM) Science Team Meeting, Monterey, California.

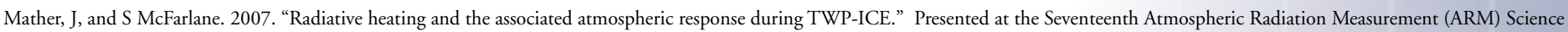
Team Meeting, Monterey, California.

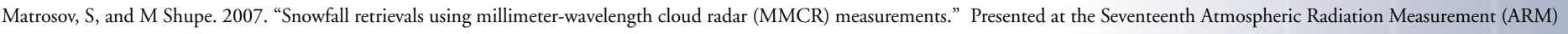
Science Team Meeting, Monterey, California.

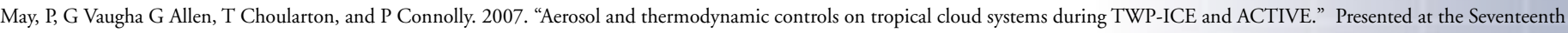
Atmospheric Radiation Measurement (ARM) Science Team Meeting, Monterey, California.

Mayor, S. 2007. “Raman-shifted eye-safe aerosol lidar (REAL).” Presented at the Seventeenth Atmospheric Radiation Measurement (ARM) Science Team Meeting, Monterey, California.

McComiskey, A, G Feingold, S Frisch, Q Min, D Turner, and M Miller. 2007. “Aerosol-cloud interactions at Point Reyes, California.” Presented at the Seventeenth Atmospheric Radiation Measurement (ARM) Science Team Meeting, Monterey, California.

McCoy, R, S Klein, R Cederwall, S Xie, R McCord, G Palanisamy, and B Horwedel. 2007. "Statistical summaries of ARM data for climate modelers - A new ARM product." Presented at the Seventeenth Atmospheric Radiation Measurement (ARM) Science Team Meeting, Monterey, California.

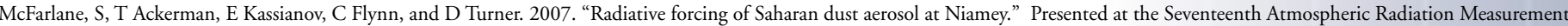
(ARM) Science Team Meeting, Monterey, California.

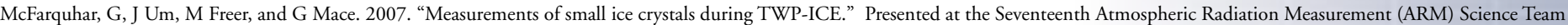
Meeting, Monterey, California.

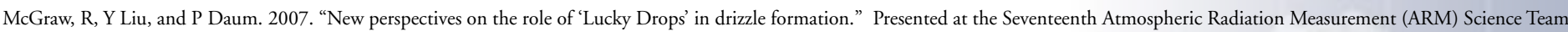
Meeting, Monterey, California.

Mechem, D, and Y Kogan. 2007. "Large eddy observations and LES of liquid stratus over the ACRF." Presented at the Seventeenth Atmospheric Radiation Measurement (ARM) Science Team Meeting, Monterey, California.

Miller, M, M Dunn, M Bartholomew, P Kollias, J Ogren, C Chu, D Turner, and P Daum. 2007. "Cloud droplet nucleation and the aerosol first indirect effect." Presented at the Seventeenth Atmospheric Radiation Measurement (ARM) Science Team Meeting, Monterey, California.

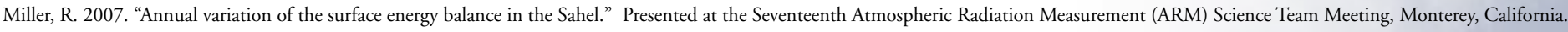

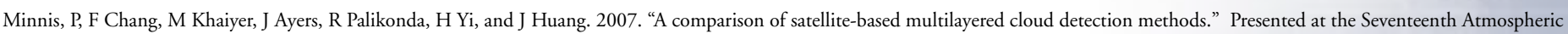
Radiation Measurement (ARM) Science Team Meeting, Monterey, California.

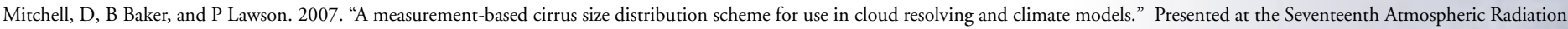
Measurement (ARM) Science Team Meeting, Monterey, California.

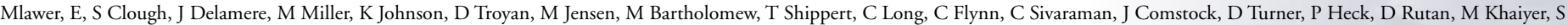

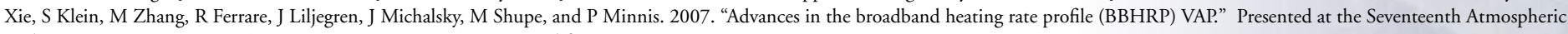
Radiation Measurement (ARM) Science Team Meeting, Monterey, California.

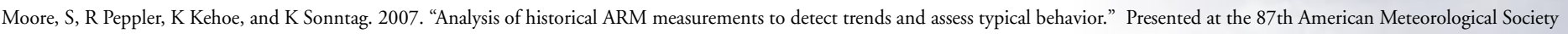
(AMS) Meeting, San Antonio, Texas.

Morcrette, J. 2007. “Impact of a new McICA radiation package in the ECMWF forecasting system.” Presented at the Seventeenth Atmospheric Radiation Measurement (ARM) Science Team Meeting, Monterey, California.

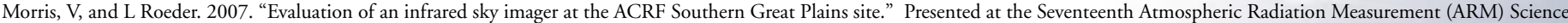
Team Meeting, Monterey, California.

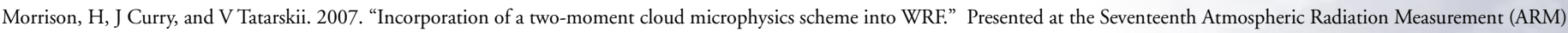
Science Team Meeting, Monterey, California.

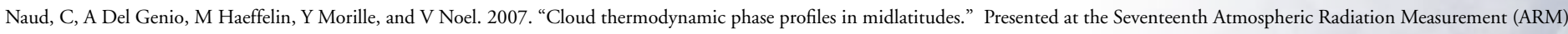
Science Team Meeting, Monterey, California.

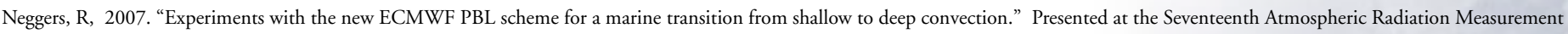
(ARM) Science Team Meeting, Monterey, California.

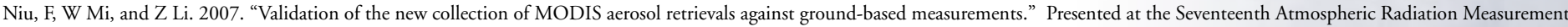
(ARM) Science Team Meeting, Monterey, California.

Oreopoulos, L, E Mlawer, J Delamere, T Shippert, D Turner, M Miller, M Khaiyer, P Minnis, S Clough, H Barker, and R Ellingson. 2007. “The continuous intercomparison of radiation codes (CIRC): Phase I cases.” Presented at the Seventeenth Atmospheric Radiation Measurement (ARM) Science Team Meeting, Monterey, California.

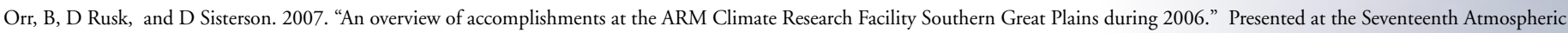
Radiation Measurement (ARM) Science Team Meeting, Monterey, California. 
Pazmany, A, and M Wolde. 2007. “Airborne G-Band (183 GHz) water vapor radiometer.” Presented at the Seventeenth Atmospheric Radiation Measurement (ARM) Science Team Meeting, Monterey, California.

Penner, J, and H Guo. 2007. "Examination of aerosol indirect effects under contrasting environments during the ACE-2 Experiment.” Presented at the Seventeenth Atmospheric Radiation Measurement (ARM) Science Team Meeting, Monterey, California.

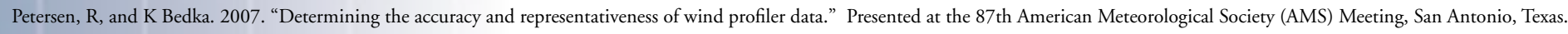

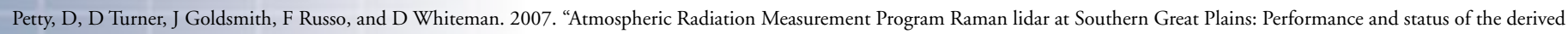
products.” Presented at the Seventeenth Atmospheric Radiation Measurement (ARM) Science Team Meeting, Monterey, California.

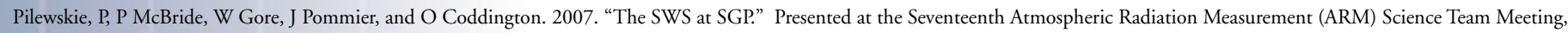
Monterey, California.

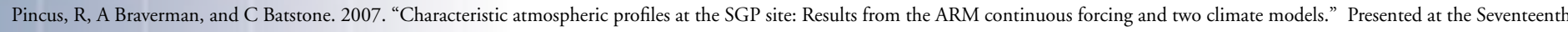
Atmospheric Radiation Measurement (ARM) Science Team Meeting, Monterey, California.

Polonsky, I, A Davis, and S Love. 2007. "Wide angle imaging lidar: Validation for clouds at night and progress toward aerosol and daytime capabilities.” Presented at the 87th American Meteorological Society (AMS) Meeting, San Antonio, Texas.

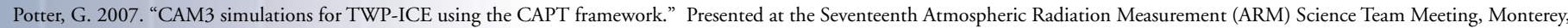
California.

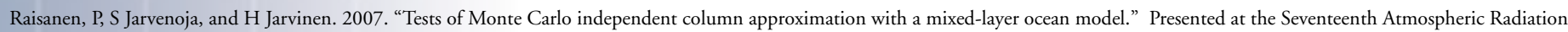
Measurement (ARM) Science Team Meeting, Monterey, California.

Reda, I, and C Webb. 2007. "ARM/NREL pyrgeometer calibrations with traceability to the world infrared standard group (WISG)”. Presented at the Seventeenth Atmospheric Radiation Measurement (ARM) Science Team Meeting, Monterey, California.

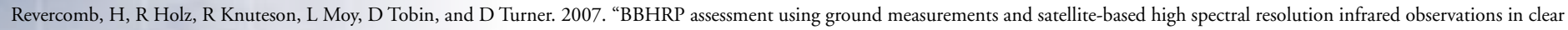
sky conditions.” Presented at the Seventeenth Atmospheric Radiation Measurement (ARM) Science Team Meeting, Monterey, California.

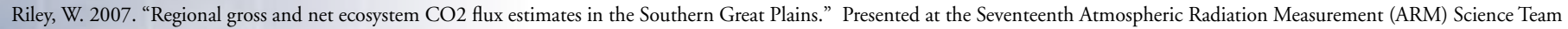
Meeting, Monterey, California.

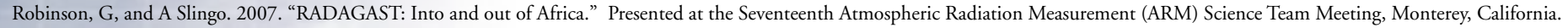

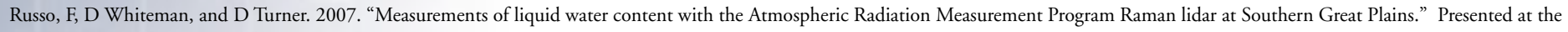
Seventeenth Atmospheric Radiation Measurement (ARM) Science Team Meeting, Monterey, California.

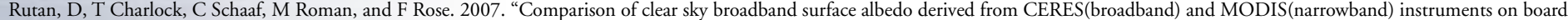
terra satellite.” Presented at the Seventeenth Atmospheric Radiation Measurement (ARM) Science Team Meeting, Monterey, California.

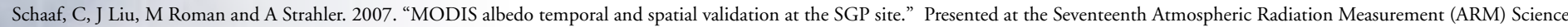
Team Meeting, Monterey, California.

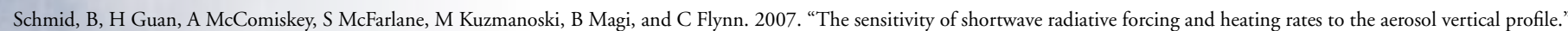
Presented at the Seventeenth Atmospheric Radiation Measurement (ARM) Science Team Meeting, Monterey, California.

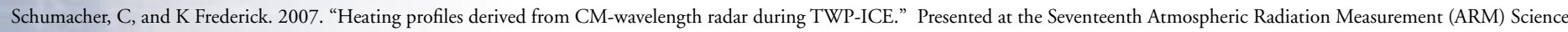
Team Meeting, Monterey, California.

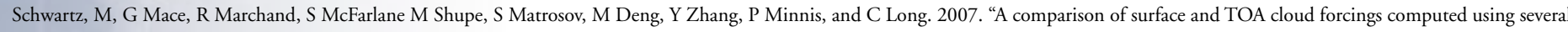
cirrus cloud property retrievals." Presented at the Seventeenth Atmospheric Radiation Measurement (ARM) Science Team Meeting, Monterey, California.

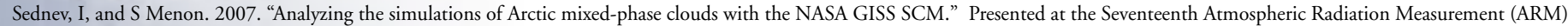
Science Team Meeting, Monterey, California.

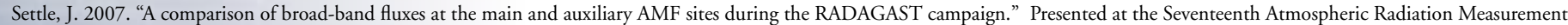
(ARM) Science Team Meeting, Monterey, California.

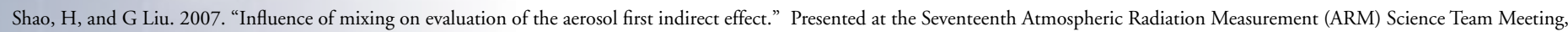
Monterey, California.

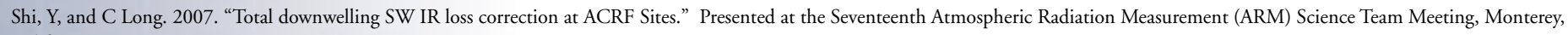
California.

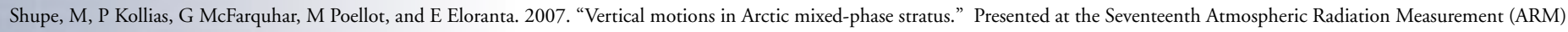
Science Team Meeting, Monterey, California.

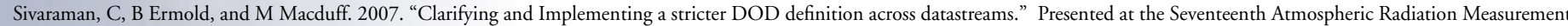
(ARM) Science Team Meeting, Monterey, California.

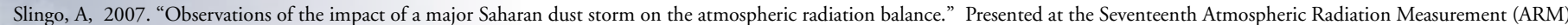
Science Team Meeting, Monterey, California.

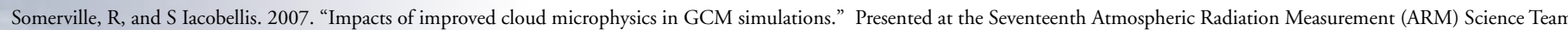
Meeting, Monterey, California.

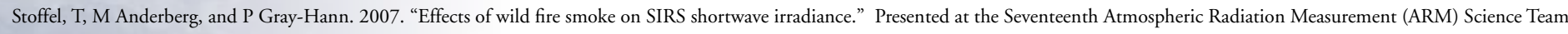
Meeting, Monterey, California.

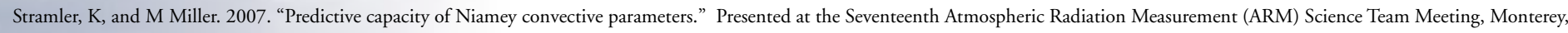
California. 


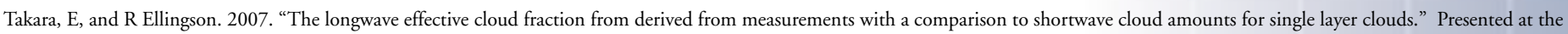
Seventeenth Atmospheric Radiation Measurement (ARM) Science Team Meeting, Monterey, California.

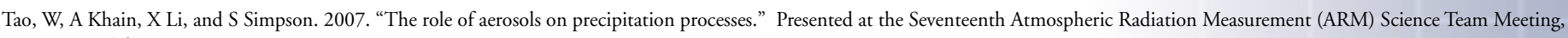
Monterey, California.

Taylor, P, and R Ellingson. 2007. “Finite cloud effects at the ACRF TWP site.” Presented at the Seventeenth Atmospheric Radiation Measurement (ARM) Science Team Meeting, Monterey, California.

Tobin, D, D Turner, L Borg, R Holz, L Moy, H Revercomb, and R Knuteson. 2007. “Cirrus cloud flux study using lidar/radar/AERI derived cloud properties.” Presented at the Seventeenth Atmospheric Radiation Measurement (ARM) Science Team Meeting, Monterey, California.

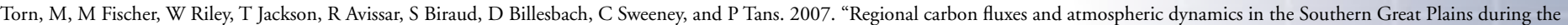
2007 NACP mid continent intensive and CLASIC.” Presented at the Seventeenth Atmospheric Radiation Measurement (ARM) Science Team Meeting, Monterey, California.

Troyan, D, M Jensen, D Turner M Miller J Delamere, E Mlawer, and G Mace. 2007. “The merged sounding VAP: Recent enhancements.” Presented at the Seventeenth Atmospheric Radiation Measurement (ARM) Science Team Meeting, Monterey, California.

Turner, D, and M Shupe. 2007. “The next generation of microbase at the NSA.” Presented at the Seventeenth Atmospheric Radiation Measurement (ARM) Science Team Meeting, Monterey, California.

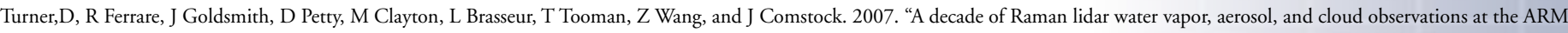
Southern Great Plains site.” Presented at the 87th American Meteorological Society (AMS) Meeting, San Antonio, Texas.

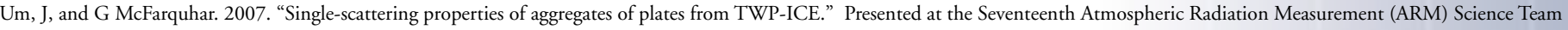
Meeting, Monterey, California.

Veron, D, M Foster, and N Barton. 2007. "Stochastic correction of the downwelling shortwave radiation in tropical, broken cloud fields and mixed-phase Arctic layer clouds." Presented at the Seventeenth Atmospheric Radiation Measurement (ARM) Science Team Meeting, Monterey, California.

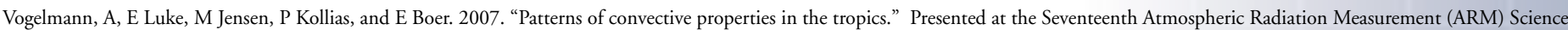
Team Meeting, Monterey, California.

Wagener, R, H Teich, D Turner and M Bartholomew. 2007. "Evaluation of the utility of routine Lagrangian trajectories as a standard ARM external data-stream." Presented at the Seventeenth Atmospheric Radiation Measurement (ARM) Science Team Meeting, Monterey, California.

Walsh, J, 2007. “Use of ARM-North Slope of Alaska for assessment of reanalysis products.” Presented at the Seventeenth Atmospheric Radiation Measurement (ARM) Science Team Meeting, Monterey, California.

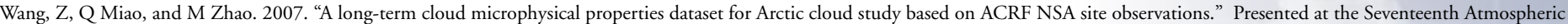
Radiation Measurement (ARM) Science Team Meeting, Monterey, California.

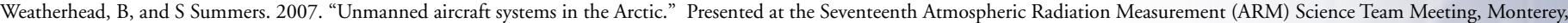
California.

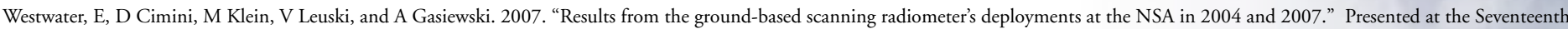
Atmospheric Radiation Measurement (ARM) Science Team Meeting, Monterey, California.

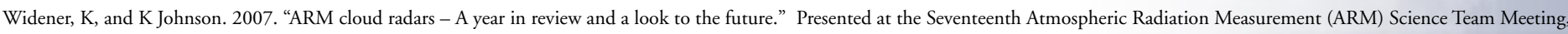
Monterey, California.

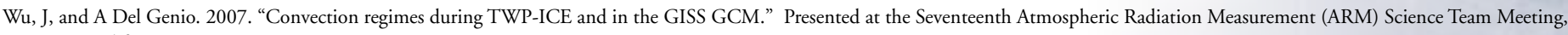
Monterey, California.

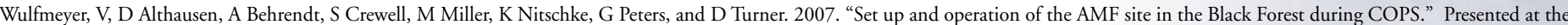
Seventeenth Atmospheric Radiation Measurement (ARM) Science Team Meeting, Monterey, California.

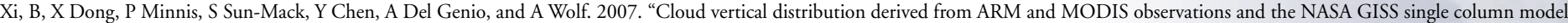
(SCM).” Presented at the Seventeenth Atmospheric Radiation Measurement (ARM) Science Team Meeting, Monterey, California.

Xie, S, R McCoy, S Klein, T Hume, C Jakob, M Zhang, and C Long. 2007. "Objective variational analysis for the Tropical Warm Pool - International Cloud Experiment." Presented at the Seventeenth Atmospheric Radiation Measurement (ARM) Science Team Meeting, Monterey, California.

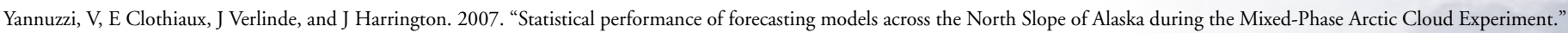
Presented at the Seventeenth Atmospheric Radiation Measurement (ARM) Science Team Meeting, Monterey, California.

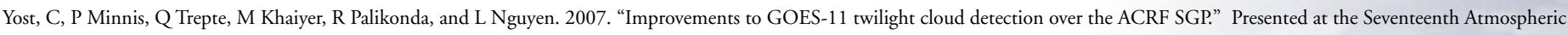
Radiation Measurement (ARM) Science Team Meeting, Monterey, California.

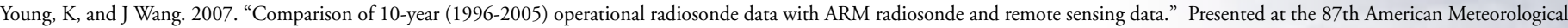
Society (AMS) Meeting, San Antonio, Texas.

Yue, Q, K Liou, and Y Gu. 2007. "Investigation of the radiative forcings of thin cirrus in the tropical atmosphere using AIRS/ARM data." Presented at the Seventeenth Atmospheric Radiation Measurement (ARM) Science Team Meeting, Monterey, California.

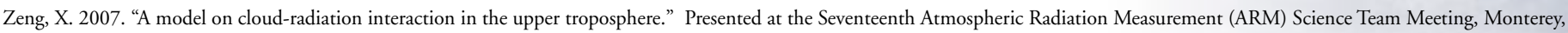
California.

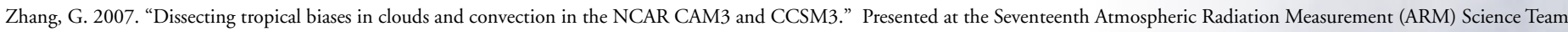
Meeting, Monterey, California.

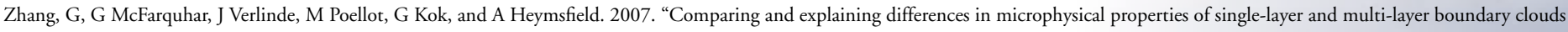
observed during MPACE.” Presented at the Seventeenth Atmospheric Radiation Measurement (ARM) Science Team Meeting, Monterey, California.

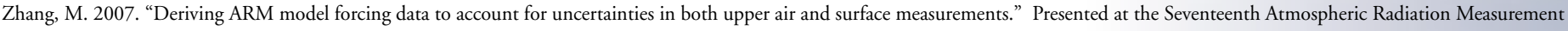
(ARM) Science Team Meeting, Monterey, California. 
Zhang, Y, and S Klein. 2007. “Diurnal cycle of deep convection.” Presented at the Seventeenth Atmospheric Radiation Measurement (ARM) Science Team Meeting, Monterey, California.

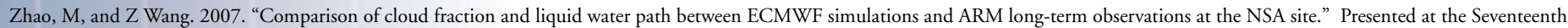
Atmospheric Radiation Measurement (ARM) Science Team Meeting, Monterey, California.

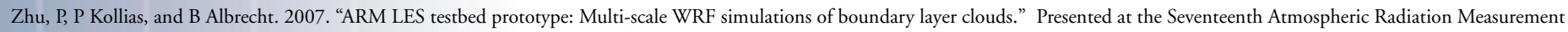
(ARM) Science Team Meeting, Monterey, California.

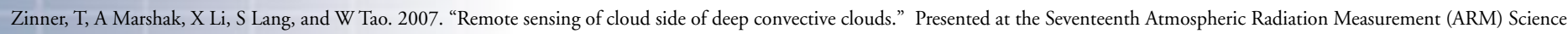
Team Meeting, Monterey, California.

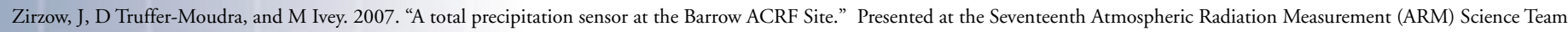
Meeting, Monterey, California.

\section{Technical Reports}

Bartholomew, M. 2007. Disdrometer and tipping bucket rain gauge instrument handbook. U.S. Department of Energy. DOE/SC-ARM/TR-079.

Caddedu, M. 2006. G-band (183 GHz) vapor radiometer (GVR) instrument handbook. U.S. Department of Energy. DOE/SC-ARM/TR-076.

Feltz, W, D Turner, H Howell, W Smith, R Knuteson, H Woolf, J Comstock, C Sivaraman, R Mahon, and T Halter. 2007. Retrieving temperature and moisture profiles from AERI radiance observations: AERIPROF value-added product technical description. U.S. Department of Energy. DOE/SC-ARM/TR-066.1.

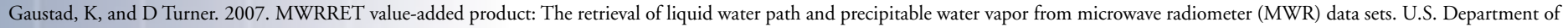
Energy. DOE/SC-ARM/TR-081.

Ghan, S. 2007. Mixed-phase cloud microphysics for global climate models: 2007 ARM metric first quarter. U.S. Department of Energy. DOE/SC-ARM-P-06-028.

Koontz, A. 2007. ACRF ingest software status: New, current, and future. U.S. Department of Energy. DOE/SC-ARM/P-07-004.2.

Liljegren, J. 2006. September monthly instrument status report. U.S. Department of Energy. DOE/SC-ARM/P-06-011.3.

Liljegren, J. 2006. October monthly instrument status report. U.S. Department of Energy. DOE/SC-ARM/P-06-011.4.

Liljegren, J. 2006. November/December monthly instrument status report. U.S. Department of Energy. DOE/SC-ARM/P-06-011.5.

Liljegren, J. 2007. January monthly instrument status report. U.S. Department of Energy. DOE/SC-ARM/P-07-002.1.

Liljegren, J. 2007. February monthly instrument status report. U.S. Department of Energy. DOE/SC-ARM/P-07-002.2.

Liljegren, J. 2007. March monthly instrument status report. U.S. Department of Energy. DOE/SC-ARM/P-07-002.3.

Liljegren, J. 2007. April monthly instrument status report. U.S. Department of Energy. DOE/SC-ARM/P-07-002.4.

Liljegren, J. 2007. May monthly instrument status report. U.S. Department of Energy. DOE/SC-ARM/P-07-002.5.

Liljegren, J. 2007. June monthly instrument status report. U.S. Department of Energy. DOE/SC-ARM/P-07-002.6.

Liljegren, J. 2007. July monthly instrument status report. U.S. Department of Energy. DOE/SC-ARM/P-07-002.7.

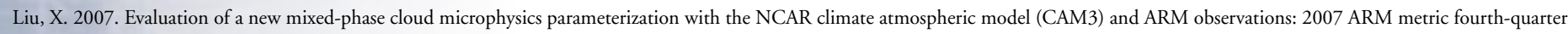
report. U.S. Department of Energy. DOE/SC-ARM/P-07-012.

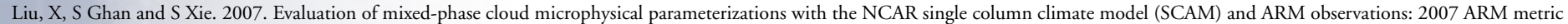
second-quarter report. U.S. Department of Energy. DOE/SC-ARM/P-07-006.

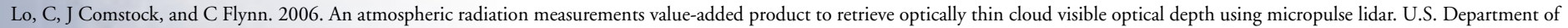
Energy. DOE/SC-ARM/TR-077.

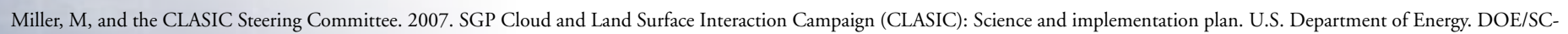
ARM-0703.

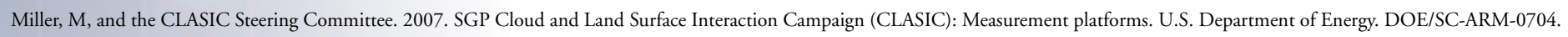

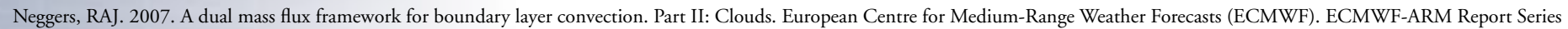
No. 3.

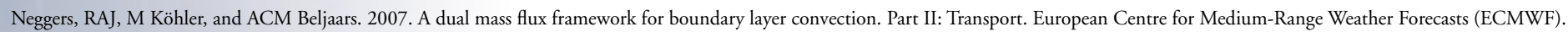
ECMWF-ARM Report Series No. 2.

Pilewskie, P, and J Pommier. 2007. Shortwave spectroradiometer (SWS) instrument handbook. U.S. Department of Energy. DOE/SC-ARM/TR-062.

Sisterson, D. 2006. ACRF operations quarterly report: July-September 2006. U.S. Department of Energy. DOE/SC-ARM/P-06-018.

Sisterson, D. 2006. ACRF operations quarterly report: October-December 2006. U.S. Department of Energy. DOE/SC-ARM/P-07-001.

Sisterson, D. 2007. ACRF operations quarterly report: January-March 2007. U.S. Department of Energy. DOE/SC-ARM/P-07-007.

Sisterson, D. 2007. ACRF operations quarterly report: April-June 2007. U.S. Department of Energy. DOE/SC-ARM/P-07-010.

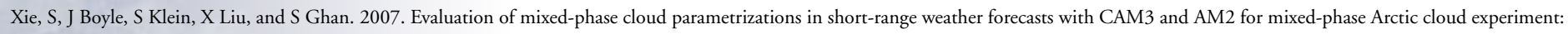
2007 ARM metric third-quarter report. U.S. Department of Energy. DOE/SC-ARM/P-07-009. 


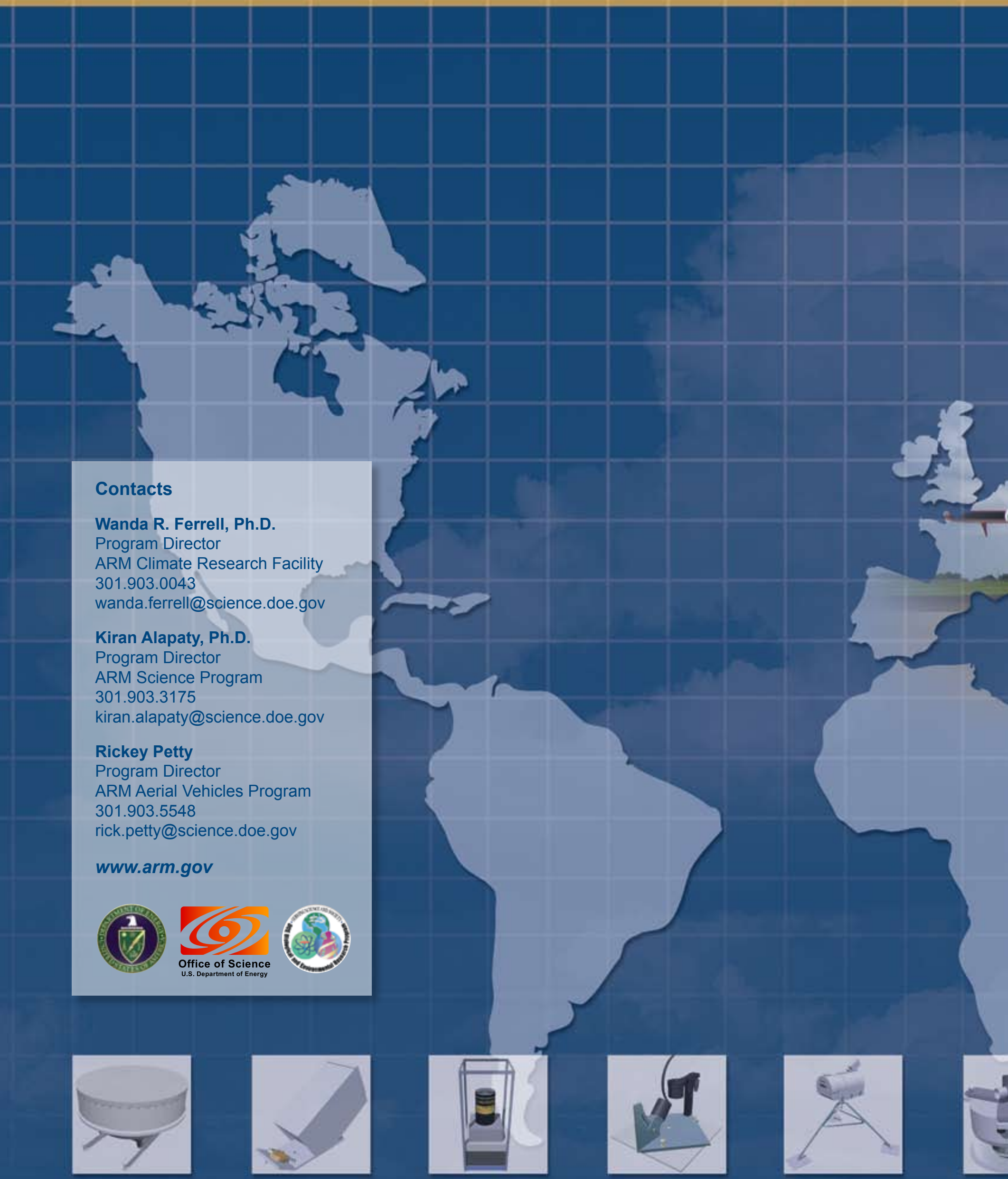

